\title{
Hydrogeology and Water Quality in the Cedar Rapids Area, lowa, 1992-96
}

By PETER M. SCHULMEYER and DOUGLAS J. SCHNOEBELEN

\section{U.S. GEOLOGICAL SURVEY}

Water-Resources Investigations Report 97-4261

Prepared in cooperation with the

THE CITY OF CEDAR RAPIDS

MUNICIPAL WATER DEPARTMENT 


\title{
U.S. DEPARTMENT OF THE INTERIOR BRUCE BABBITT, Secretary
}

\author{
U.S. GEOLOGICAL SURVEY \\ THOMAS J. CASADEVALL, Acting Director
}

The use of firm, trade, and brand names in this report is for identification purposes only and does not constitute endorsement by the U.S. Geological Survey.

For addtional information write to:

Copies of this report can be purchased from:

District Chief

U.S. Geological Survey

Water Resources Division

400 South Clinton Street

lowa City, lowa 52244
U.S. Geological Survey

Information Services

Box 25286

Denver Federal Center

Denver, CO 80225-0286 


\section{CONTENTS}

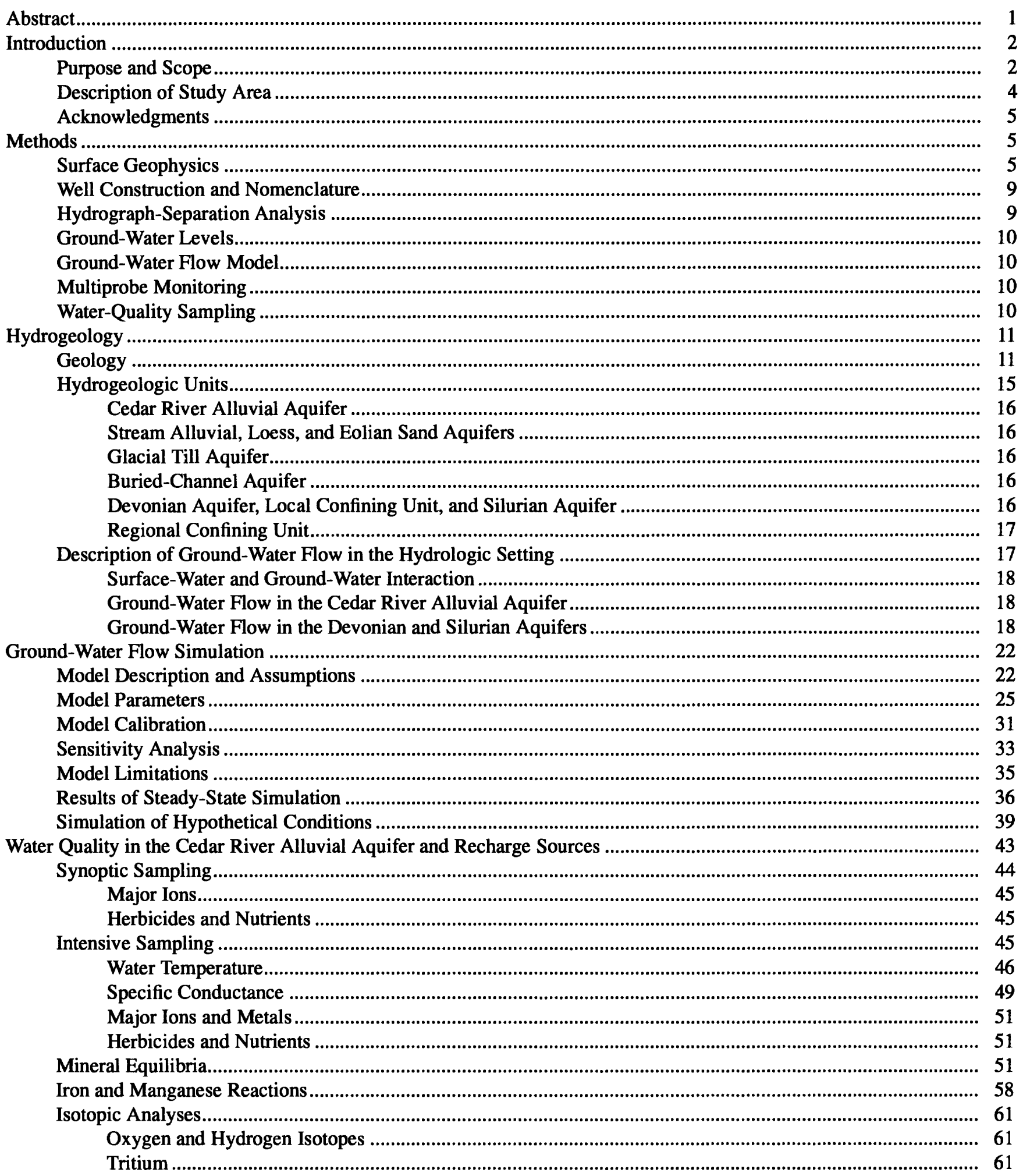




\section{FIGURES}

1-5. Maps showing:

1. Location of model area, detailed study area, and hydrogeologic section $A-A^{\prime}$.

2. Detailed study area showing location of municipal well fields, selected private and industrial wells, and location of hydrogeologic section $A-A^{\prime}$.

3. Location of selected municipal and observation wells in Seminole Well Field.

4. Location of selected municipal and observation wells in West Well Field

5. Location of selected municipal and observation wells in East Well Field.

6. Hydrogeologic section $A-A$ ' showing model layers

7-15. Maps showing:

7. Surficial geology of model area

8. Potentiometric surface of the Devonian and Silurian aquifers, June through August 1993 .

9. Hydrogeologic units assigned to model layer 1 .......

10. Hydrogeologic units assigned to model layer 2

11. Model grid, river cells, drain cells, dry cells, pumping cells, and boundary of model layer 1 .............

12. Model grid, boundary conditions, dry cells, and pumping cells for model layer 2

13. Model grid, boundary conditions, and pumping cells for model layer 3

14. Simulated potentiometric surface for model layer 3 .

15. Location of subbasins in model area

\section{6-17. Graphs showing:}

16. Root mean square error between measured and simulated water levels as a result of varying model input parameters by a multiplication factor

17. Proportion of simulated inflow and outflow obtained from river leakage as a result of varying model input parameters by a multiplication factor

18-19. Diagram showing:

18. Model-calculated water-budget components for three layers of ground-water flow model with no wells pumping.

19. Model-calculated water-budget components for three layers of ground-water flow model with all wells pumping.

20. Map showing simulated areas of contribution for 1-, 5-, and 10-year periods for Cedar Rapids municipal wells

21-22. Diagrams showing:

21. Model-calculated water-budget components for three layers of ground-water flow model with wells pumping for less-than-average annual precipitation for 1961-90 scenario.....

22. Features of intensive study sites near Cedar Rapids municipal wells (A) Seminole 1 and (B) Seminole 10.

23-28. Graphs showing:

23. Water temperatures in the Cedar River, observation well CRM-4, and observation well CRM-3 near Cedar Rapids, Iowa, February 1993 through January $1994 .$.

4. Water temperatures in the Cedar River, observation well CRM-10, and observation well CRM-9 near

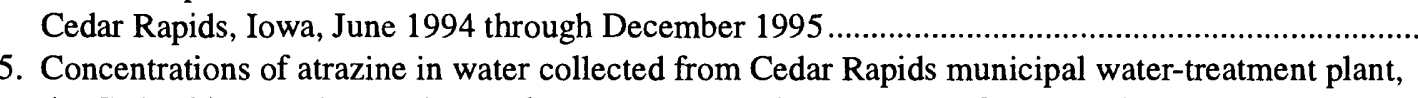
the Cedar River, and municipal wells Seminole 1 and Seminole 10 from October 1992 through June 1994 ..

26. Saturation indices for common minerals in water samples collected from Cedar Rapids municipal well Seminole 10, Cedar Rapids, Iowa.

7. Saturation indices for common minerals in water samples collected from Cedar Rapids municipal well Seminole 1, Cedar Rapids, Iowa.

8. Results of oxygen and deuterium isotope analysis for selected sample sites near Cedar Rapids, Iowa, April 1995 
TABLES

1. Geologic and hydrogeologic units in model area, range of hydraulic conductivity, and equivalent model layer.. 13

2. Calculated base-flow discharge of selected streams near model area

3. Altitude of water surface for selected observation wells and stage of the Cedar River from November 1993 through April 1996

4. Simulated ground-water discharge to selected subbasins in model area and to the Cedar River.........

5. Model-calculated water budget for steady-state conditions

6. Model-calculated water budget for Cedar River alluvial aquifer under presumed steady-state conditions

7. Model-calculated water budget for Cedar River alluvial aquifer under presumed steady-state conditions for the increased pumping scenario...

8. Herbicide and nutrient concentrations in ground-water samples collected during synoptic sampling of Cedar River alluvial, Devonian, and Silurian aquifers, November 1993.

9. Selected water-quality constituents in ground-water and surface-water samples collected at Cedar Rapids, Iowa, 1992-94

10. Saturation indices for common minerals in water samples collected during synoptic sampling, November 199356

11. Tritium values for water samples collected during April 1995

12. Information for selected wells and surface-water sites near Cedar Rapids, Iowa 


\begin{tabular}{|c|c|c|}
\hline Multiply & by & To obtaln \\
\hline inch (in.) & 25.4 & millimeter \\
\hline foot $(f t)$ & 0.3048 & meter \\
\hline mile (mi) & 1.609 & kilometer \\
\hline square mile $\left(\mathrm{mi}^{2}\right)$ & 2.590 & square kilometer \\
\hline gallon (gal) & 3.785 & liter \\
\hline million gallons (Mgal) & 3,785 & cubic meter \\
\hline million gallons per day $(\mathrm{Mgal} / \mathrm{d})$ & 3,785 & cubic meter per day \\
\hline gallon per day per foot $[(\mathrm{gal} / \mathrm{d}) / \mathrm{ft}]$ & $1.438 \times 10^{-7}$ & meter squared per second \\
\hline gallon per minute $(\mathrm{gal} / \mathrm{min})$ & 0.631 & liter per second \\
\hline gallon per minute per foot $[(\mathrm{gal} / \mathrm{min}) / \mathrm{ft}]$ & 0.2070 & liter per second per meter \\
\hline inch per year (in/yr) & 25.4 & millimeter per year \\
\hline foot per day (ft/d) & 0.3048 & meter per day \\
\hline cubic foot per second per mile squared $\left.\left[\left(\mathrm{ft}^{3} / \mathrm{s}\right) / \mathrm{mi}^{2}\right)\right]$ & 10.93 & liter per second per kilometer squared \\
\hline cubic foot per mile squared $\left(\mathrm{ft}^{3} / \mathrm{mi}^{2}\right)$ & 10.93 & liter per kilometer squared \\
\hline foot squared per day $\left(\mathrm{ft}^{2} / \mathrm{d}\right)$ & 0.0929 & meter squared per day \\
\hline cubic foot $\left(\mathrm{ft}^{3}\right)$ & 28.32 & liter \\
\hline cubic foot per second $\left(\mathrm{ft}^{3} / \mathrm{s}\right)$ & 0.02832 & cubic meter per second \\
\hline cubic foot per day $\left(\mathrm{ft}^{3} / \mathrm{d}\right)$ & 0.02832 & cubic meter per day \\
\hline foot per second $(\mathrm{ft} / \mathrm{s})$ & 0.3048 & meters per second \\
\hline gallon per year (gal/yr) & $1.20 \times 10^{-10}$ & cubic meter per second \\
\hline
\end{tabular}

Temperature in degrees Fahrenheit $\left({ }^{\circ} \mathrm{F}\right)$ can be converted to degrees Celsius $\left({ }^{\circ} \mathrm{C}\right)$ or vice versa as follows:

$$
\begin{gathered}
{ }^{\circ} \mathrm{C}=\left({ }^{\circ} \mathrm{F}-32\right) / 1.8 \\
{ }^{\circ} \mathrm{F}=9 / 5\left({ }^{\circ} \mathrm{C}\right)+32 .
\end{gathered}
$$

Abbreviated water-quality units used in this report: Chemical concentrations are given in metric units. Chemical concentrations are given in milligrams per liter $(\mathrm{mg} / \mathrm{L})$, in micrograms per liter $(\mu \mathrm{g} / \mathrm{L})$, in picocuries per liter (pCi/L), or microsiemens per centimeter at 25 degrees celsius $(\mu \mathrm{S} / \mathrm{cm})$. Milligrams per liter and micrograms per liter are units expressing the concentration of chemical constituents in solution as weight (milligrams or micrograms) of solute per unit volume (liter) of water. For concentrations less than 7,000 $\mathrm{mg} / \mathrm{L}$, the numerical value of milligram per liter is equivalent to parts per million. The numerical value of micrograms per liter is equivalent to parts per billion.

Sea Level: In this report, "sea level" refers to the National Geodetic Vertical Datum of 1929 (NGVD of 1929) - a geodetic datum derived from a general adjustment of the first-order level nets of both the United States and Canada, formerly called Sea Level Datum of 1929. 


\title{
Hydrogeology and Water Quality in the Cedar Rapids Area, lowa, 1992-96
}

\author{
By Peter M. Schulmeyer and Douglas J. Schnoebelen
}

\section{Abstract}

The U.S. Geological Survey (USGS) and the city of Cedar Rapids conducted a cooperative study from 1992 to 1996 to assess the hydrogeology and water quality in the Cedar River, Cedar River alluvial aquifer, Devonian aquifer, and Silurian aquifer in a 231-square-mile area of Benton and Linn Counties near Cedar Rapids, Iowa. The city of Cedar Rapids withdrew an average of 34 million gallons per day between July 1, 1995, and June 30, 1996, from the Cedar River alluvial aquifer for its drinking-water supply.

The ground-water flow system in the 231-square-mile area was simulated using a modular, three-dimensional, finite-difference groundwater flow model (MODFLOW) under steady-state conditions. The three-layer groundwater flow model simulates ground-water flow in layer 1 for unconsolidated deposits that include the Cedar River alluvial aquifer; in layer 2 for the Devonian aquifer and buried-channel aquifer; and in layer $\mathbf{3}$ for the Silurian aquifer. Primary sources of inflow to the ground-water flow system in the model area include infiltration of precipitation (63.5 percent) and leakage from the Cedar River (34.7 percent). Pumpage from municipal, industrial, and private wells accounts for about 48.3 percent of system outflow.

Primary sources of inflow to the Cedar River alluvial aquifer include leakage from the Cedar River (74.2 percent), leakage from adjacent or underlying hydrogeologic units (20.9 percent), and infiltration of precipitation (4.9 percent). Pumpage by municipal water-supply wells from the alluvial aquifer accounts for about 78.0 percent of system outflow.

Simulations of two hypothetical conditions using the steady-state ground-water flow model were conducted to evaluate quantitative changes on sources of water to the Cedar River alluvial aquifer. Results for the scenario representing a period of less-than-average annual precipitation for 1961-90 indicate a 32.0-percent reduction of total ground-water flow and a 5.7-percent increase in river leakage to the Cedar River alluvial aquifer. Results for the scenario representing increased pumping from the Cedar River alluvial aquifer, with pumping increased 68.3 percent from about 41 million gallons per day (for the calibrated model) to about 70 million gallons per day, indicate a 70.9-percent increase in simulated river leakage.

Commonly used herbicides in Iowa such as atrazine (and the metabolite products deethylatrazine and deisopropylatrazine), cyanazine, and metolachlor, when detected in the Cedar River alluvial aquifer, were typically at small concentrations (less than 1.0 microgram per liter). Atrazine concentrations in 26 of the 64 wells sampled were less than the 0.05 microgram per liter minimum reporting level. Most ground-water samples collected from the Devonian and Silurian aquifers had herbicide concentrations less than 0.05 microgram per liter. Nitrite-plus-nitrate nitrogen (nitrate) concentrations in ground-water samples varied from less than the minimum reporting level (0.05 milligram per liter) to 15.0 milligrams per liter. Nitrate was not detected in samples from 18 wells, and nitrate concentrations greater than the Maximum Contaminant Level for nitrate as nitrogen (10 milligrams per liter) were detected in samples from 4 wells.

Several areas in the Cedar River alluvial aquifer with large iron and manganese concentrations could be related to the original depositional environment of the sediment. In general, large iron and manganese concentrations in ground water are often associated with abundant organic and argillaceous material in sediment near old meander channels and sloughs. 


\section{INTRODUCTION}

The Cedar River alluvial aquifer is the primary source of drinking water for the city of Cedar Rapids, Iowa. The Cedar Rapids municipal water department pumped an average of $34 \mathrm{Mgal} / \mathrm{d}$ between July 1,1995 , and June 30,1996, and has a system capacity of 65 Mgal/d (John North, Cedar Rapids Water Department, written commun., 1996). Sources of recharge to the alluvial aquifer include infiltration of precipitation, runoff from adjacent upland areas, leakage from adjacent hydrogeologic units, and leakage from the Cedar River.

Investigations of water quality in the Cedar River alluvial aquifer and the Devonian and Silurian aquifers in the Cedar Rapids area indicate that dissolved solids, iron, manganese, and nitrate concentrations were variable (Hansen, 1970). Large dissolved-solids concentrations with calcium carbonate concentrations greater than $100 \mathrm{mg} / \mathrm{L}$ can cause scaling in pipes, water heaters, and boilers (Hem, 1985). Iron and manganese concentrations greater than the Secondary Maximum Contaminant Level (SMCL) $(300 \mu \mathrm{g} / \mathrm{L}$ iron and $50 \mu \mathrm{g} / \mathrm{L}$ manganese) set by the U.S. Environmental Protection Agency (1986) can plug well screens, stain laundry, and significantly affect the taste and odor of water (U.S. Environmental Protection Agency, 1986). Iron concentrations above $1,000 \mu \mathrm{g} / \mathrm{L}$ are difficult to remove from the water (Bob Glass, Cedar Rapids Water Department, written commun., 1996).

Nitrate-as-nitrogen concentrations greater than the Maximum Contaminant Level (MCL) of $10 \mathrm{mg} / \mathrm{L}$ (U.S. Environmental Protection Agency, 1986) can lead to methemoglobinemia - the "blue-baby syndrome"-and are suspected of causing the formation of carcinogenic nitrosamines and nitrosamides (Neil, 1989).

Recent investigations in Iowa and other parts of the Midwest have indicated that herbicides and nitrate are constituents in nonpoint sources of contamination (Hallberg, 1989; Kolpin and others, 1991; Holden and others, 1992). A study by Wang and Squillace (1994) at a site approximately $6 \mathrm{mi}$ southeast of Cedar Rapids indicated that the Cedar River has a substantial effect on water quality in the adjacent Cedar River alluvial aquifer. Concentrations of herbicides, such as alachlor, atrazine, cyanazine, and metolachlor in water samples collected from observation wells ranging from 3 to $42 \mathrm{ft}$ deep and at distances ranging from 5 to $150 \mathrm{ft}$ from the Cedar River, were greater during flooding than background concentrations in water collected from wells at distances greater than $150 \mathrm{ft}$ from the Cedar River. Kolpin and others (1991), in their Midcontinent ground-water study, showed that water collected from wells located within $100 \mathrm{ft}$ of a stream was more likely to contain concentrations of herbicides than water from wells located farther away.

Alluvial aquifers adjacent to large rivers are particularly vulnerable to the dynamics of surface- and ground-water interactions resulting from infiltration of river water (Squillace and others, 1993). During periods of snowmelt or rainfall runoff, increases in river stage can result in the infiltration of river water through the river bottom and river bank into the adjacent aquifer (Squillace and others, 1996). The infiltrated river water can contain herbicides and nutrients (Squillace and others, 1996). Induced infiltration of river water into the adjacent alluvial aquifer can occur in the vicinity of pumping well fields (Schulmeyer, 1995).

The U.S. Geological Survey (USGS) and the city of Cedar Rapids conducted a cooperative study from 1992-96 to assess the hydrogeology and water quality near Cedar Rapids, Iowa (fig. 1). Improved understanding of ground-water flow, the interaction between the river and ground water, and the temporal and spatial distribution of water quality in the alluvial aquifer will aid the city of Cedar Rapids and other water users in making informed decisions about the development of the water resource.

\section{Purpose and Scope}

This report describes the hydrogeology of a $231-\mathrm{mi}^{2}$ area in Benton and Linn Counties near Cedar Rapids, Iowa, and the temporal and spatial variations of selected water-quality properties and constituents of the Cedar River, the Cedar River alluvial aquifer, the Devonian aquifer, and the Silurian aquifer from 1992-96. Also included in the report are discussions of: (1) construction of a steady-state ground-water flow model for the 231- $\mathrm{mi}^{2}$ model area, (2) sources of recharge to the Cedar River alluvial aquifer, (3) quantitative changes in recharge to the Cedar River alluvial aquifer from individual sources for a model scenario with current pumping from the Cedar River alluvial aquifer and the assumed less-than-average annual precipitation for 1961-90, and (4) quantitative changes in recharge sources for a model scenario with increased (hypothetical) pumping from the Cedar River alluvial aquifer. 


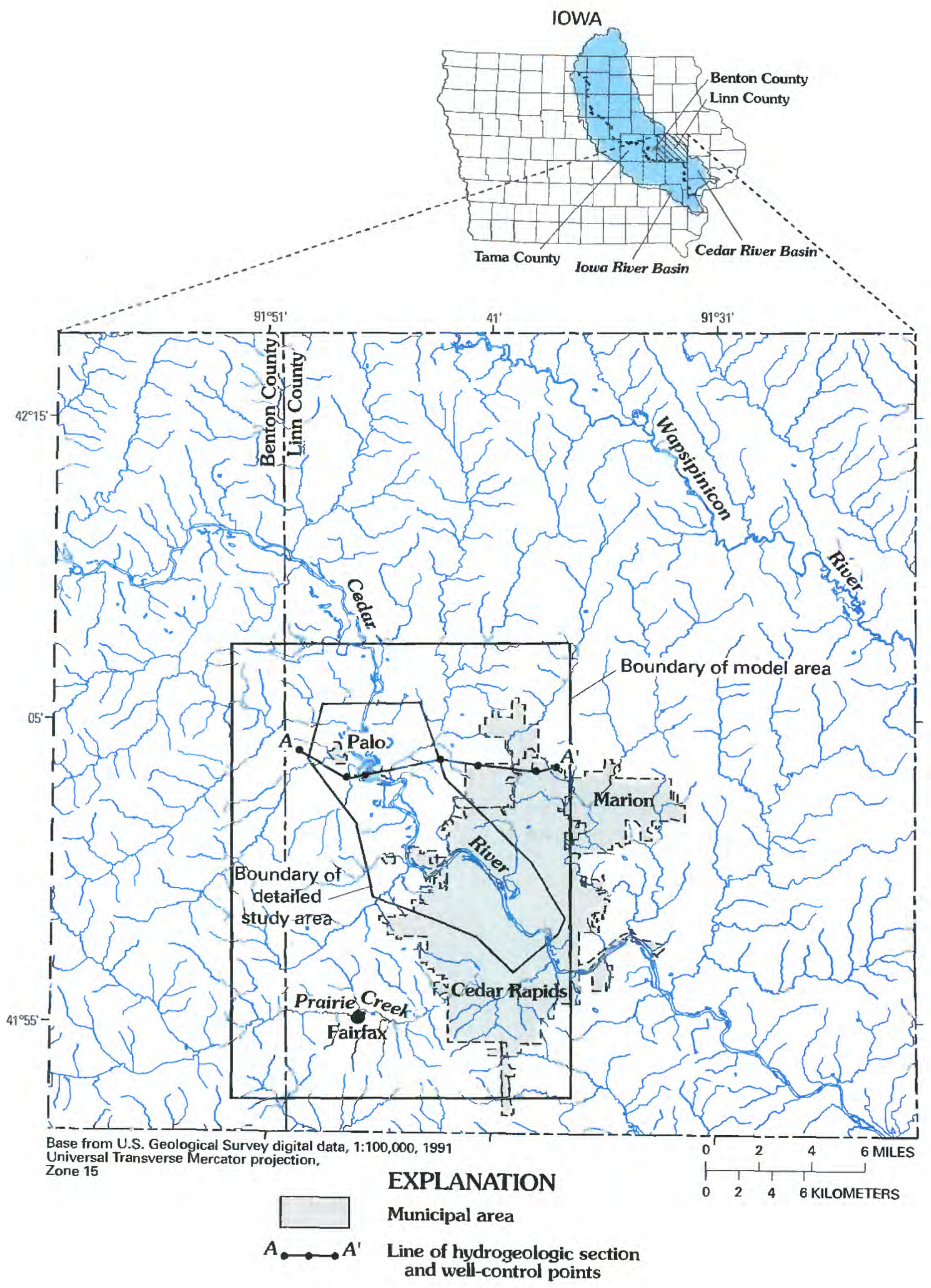

Figure 1. Location of model area, detailed study area, and hydrogeologic section $A-A$ '. 


\section{Description of Study Area}

The study area encompasses a $231-\mathrm{mi}^{2}$ area surrounding a portion of the Cedar River alluvial aquifer that is located between Cedar Rapids and Palo in Benton and Linn Counties, Iowa. For purposes of discussion within this report, the study area is described in terms of a model area and a detailed study area (fig. 1). The term "model area" refers to the $231-\mathrm{mi}^{2}$ study area and indicates a ground-water flow model was constructed of that area (fig. 1). The detailed study area is part of the model area used for discussion of water quality in the report (fig. 1). The detailed study area encompasses the Seminole, West, and East Municipal Well Fields located adjacent to the Cedar River (fig. 2).

The model area has a well-developed stream pattern that drains into the Cedar River, the largest tributary to the Iowa River. The Cedar River flows in a northwest-to-southeast direction through the model area (fig. 1). Approximately $1 \mathrm{mi}$ southeast of the East Well Field is a low-head dam used for flood control and generation of hydroelectric power. A continuous-

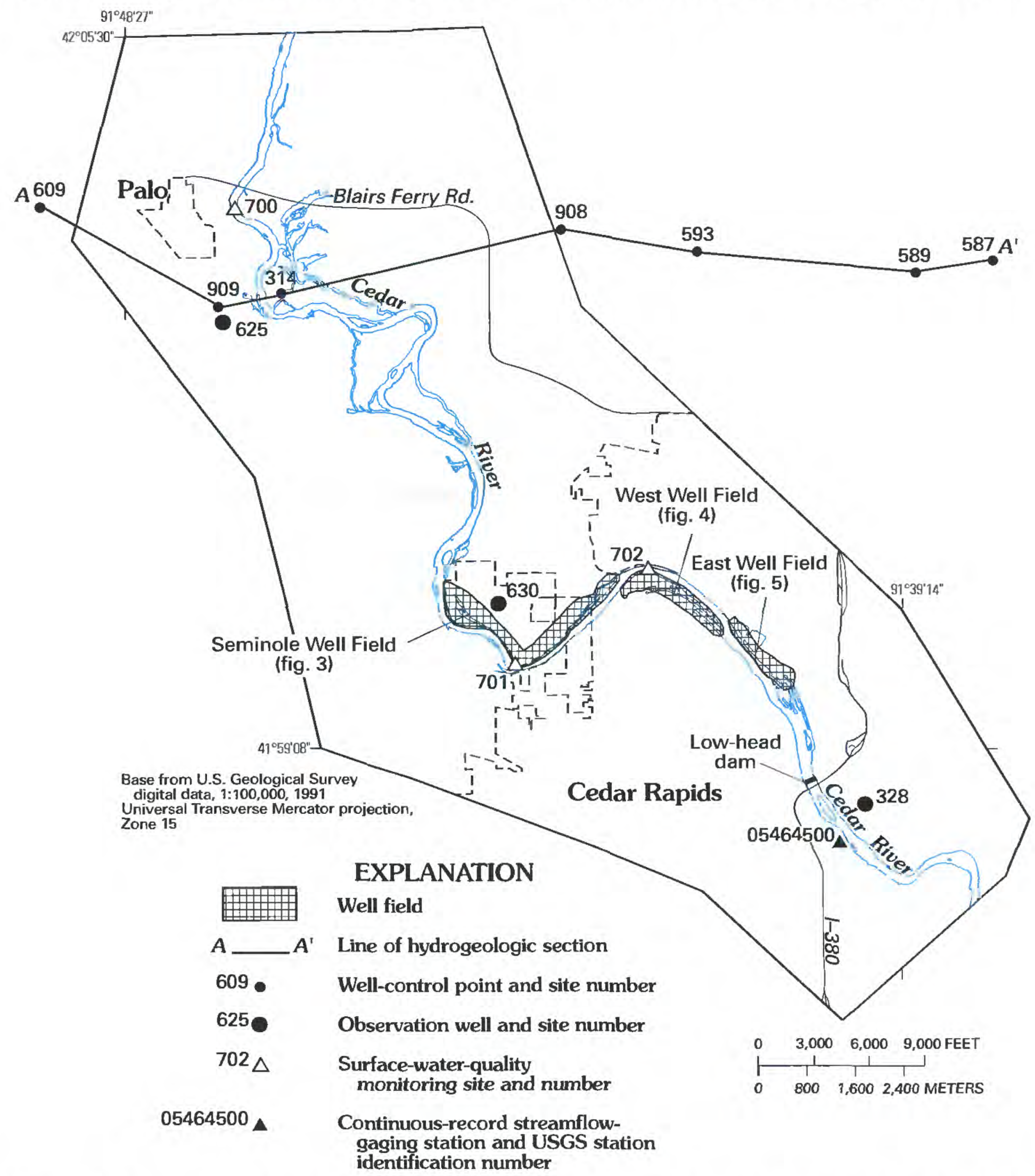

Figure 2. Detailed study area showing location of municipal well fields, selected private and industrial wells, and location of hydrogeologic section $A-A^{\prime}$. 
record streamflow-gaging station (05464500, Cedar River at Cedar Rapids) is located approximately $1 \mathrm{mi}$ downstream from the low-head dam (fig. 2).

The Cedar River Basin upstream from the streamflow-gaging station at Cedar Rapids has an area of $6,510 \mathrm{mi}^{2}$. Land use in the Cedar River Basin is predominantly agricultural (81 percent), and major crops are corn and soybeans (U.S. Department of Agriculture, 1976). Annual precipitation ranges from 24 to $60 \mathrm{in} / \mathrm{yr}$ with a mean annual rainfall of $36.4 \mathrm{in} / \mathrm{yr}$ for the period from 1961-90 (Owenby and Ezell, 1992). Air temperature normally ranges from about -18 to $100^{\circ} \mathrm{F}$ (Iowa Department of Environmental Quality, 1976). Flow in the Cedar River ranged from $140 \mathrm{ft}^{3} / \mathrm{s}$ in 1989 to $71,500 \mathrm{ft}^{3} / \mathrm{s}$ in 1961 . The Cedar River has an annual mean flow of $3,670 \mathrm{ft}^{3} / \mathrm{s}$ for the period of record, 1903-94 (May and others, 1994).

The city of Cedar Rapids has three municipal well fields located adjacent to the Cedar River (fig. 2). The three well fields have 53 vertical wells -23 wells in Seminole Well Field (fig. 3; table 12 in "Supplemental Information" section), 11 wells in the West Well Field (fig. 4; table 12 in "Supplemental Information" section), and 19 wells in the East Well Field (fig. 5; table 12 in "Supplemental Information" section). The municipal wells are located in the Cedar River flood plain, and some wells become inundated at flood stage. The municipal wells are drilled to the top of the bedrock (limestone of the Devonian System) with depths ranging from 42 to $72 \mathrm{ft}$ (table 12 in "Supplemental Information" section) and are located 30 to $900 \mathrm{ft}$ from the river. Two horizontal collector wells were constructed during 1995 and are located on the opposite bank of the Cedar River across from the Seminole Well Field. Collector well 1 is located west of Seminole well 10 (site 40), and collector well 2 is located south of Seminole well 18 (site 48). These collector wells are constructed with a central column extending to a depth of about $60 \mathrm{ft}$ and six lateral screens extending outward about $200 \mathrm{ft}$ from the central column. Each collector well is estimated to yield between 7 and $10 \mathrm{Mgal} / \mathrm{d}$ (John North, Cedar Rapids Water Department, written commun., 1995).

\section{Acknowledgments}

The authors would like to thank G. Ludvigson of the Iowa Department of Natural Resources, Geological Survey Bureau, for use of geologic maps of Linn County. The assistance of the officials and other per- sonnel of the city of Cedar Rapids in well drilling, water-quality sample and hydrologic data collection, and for providing well information is appreciated. The authors also would like to thank the following landowners for granting permission to access their property for collection of geophysical data, construction of observation wells, and for access to private wells for water-quality sample collection: T. Gruber, R.J. Kilberger, J. Kindred, J. Kwapil, A. Loan, D. Loan, M. Lynch, W. Martin, K. Schatzle, T. Watson, and the Pepsi bottling plant of Cedar Rapids, Iowa.

\section{METHODS}

Hydrogeologic data-collection locations used in the study include geophysical-data sites, ground-water sites [municipal wells, observation wells, industrial wells, and domestic wells (figs. 3, 4, and 5)], and surface-water sites (Cedar River). Selected data used in this report are listed in table 12 (in the "Supplemental Information" section), and all data collected for this study are reported in Schnoebelen and Schulmeyer (1996). Observation wells were installed to measure ground-water levels, collect water-quality samples, and monitor selected water-quality properties and constituents. Ground-water and surface-water samples were collected to describe the spatial and temporal variations of selected water-quality properties and constituents in the Cedar River alluvial aquifer, Devonian aquifer, Silurian aquifer, and the Cedar River. Samples were analyzed for major ions, nutrients, iron and manganese, dissolved organic carbon, selected herbicides, and selected environmental isotopes.

\section{Surface Geophysics}

Continuous geophysical seismic-reflection and seismic-refraction surveys were used to estimate the depth to bedrock and thickness of the Cedar River alluvium along the Cedar River between Cedar Rapids and Palo in Linn County, lowa. The contact between the bedrock and the alluvium was determined using geophysical seismic data due to the sharp contrast between the acoustical velocities of the limestone or dolomite $(15,000 \mathrm{ft} / \mathrm{s})$ and unconsolidated alluvium $(5,000 \mathrm{ft} / \mathrm{s})$ (Haeni, 1988).

A low-frequency, continuous seismic-reflection survey was conducted from a boat on the Cedar River. The low-frequency, continuous seismic-reflection sys- 


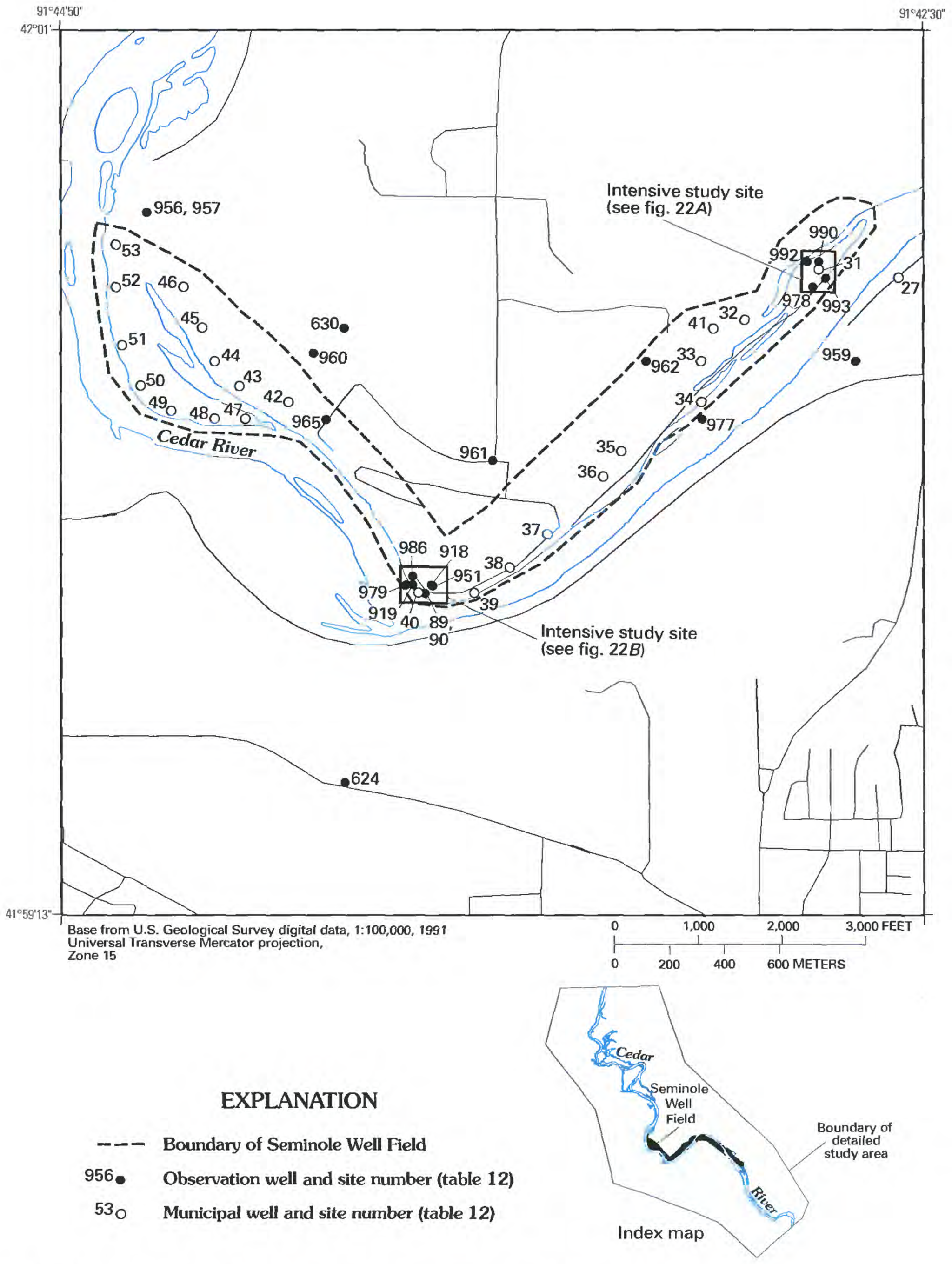

Figure 3. Location of selected municipal and observation wells in Seminole Well Field. 


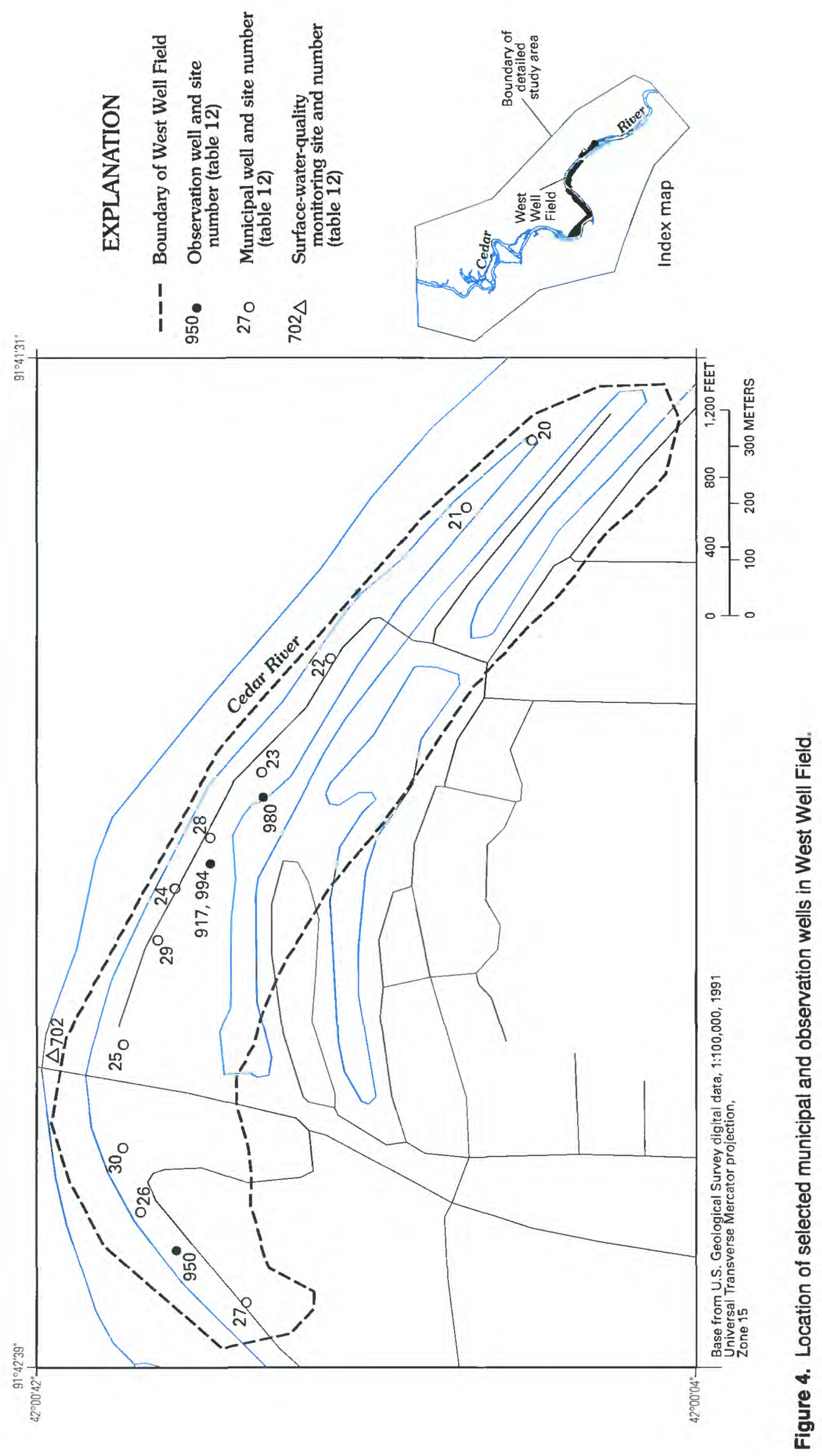




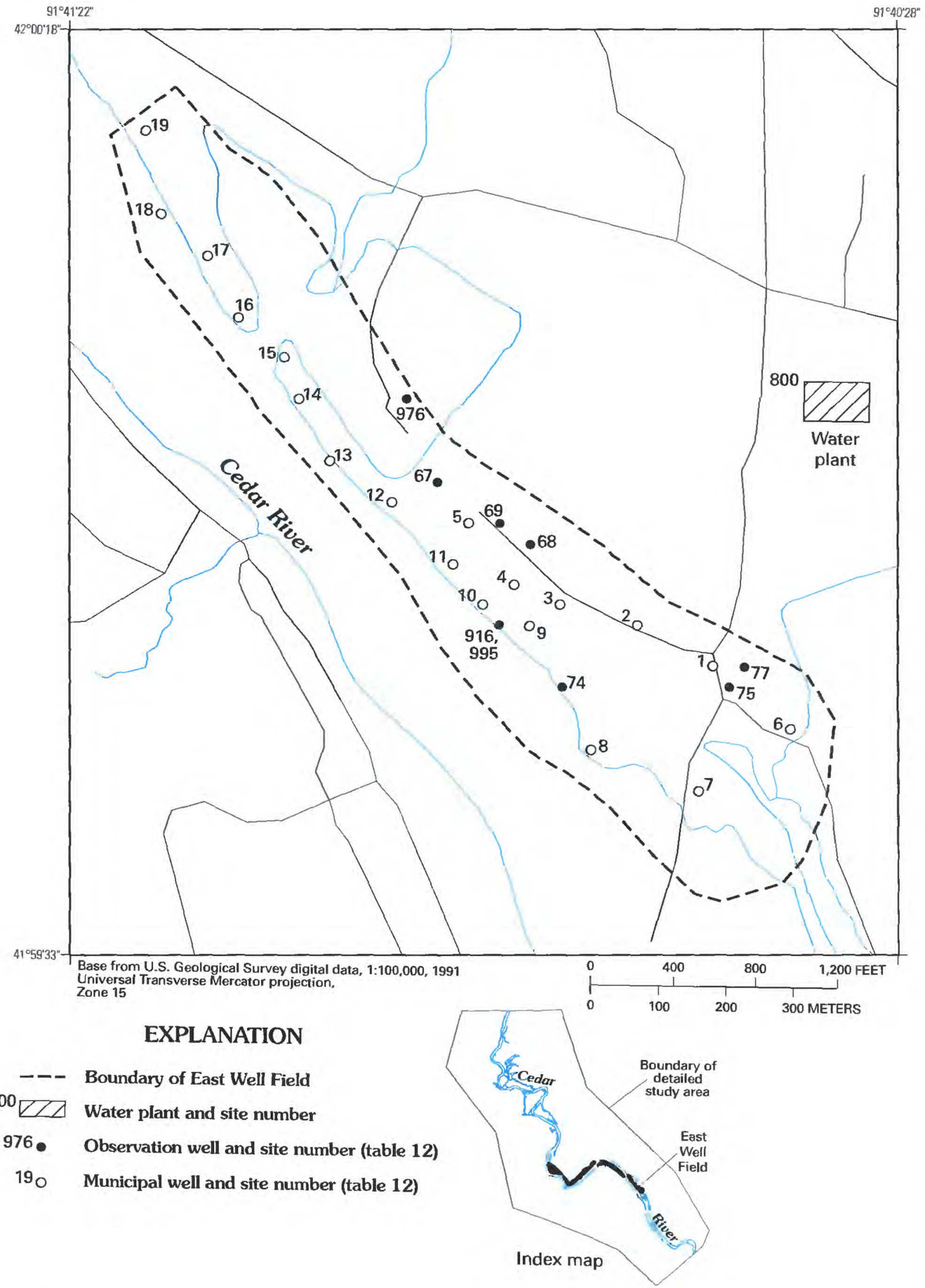

Figure 5. Location of selected municipal and observation wells in East Well Field. 
tem consists of several components - $a$ filter-amplifier unit, 455-joule sound source, hydrophone streamer, global positioning system (GPS), digital tape recorder, portable generator, and a graphic recorder. A velocity of $5,000 \mathrm{ft} / \mathrm{s}$ for alluvium was used to calculate depth, in feet.

$$
d=V t / 2
$$

where $\quad d$ is depth in feet,

$V$ is the velocity of sound in the layer in feet per second, and

$t$ is the recorded two-way traveltime of the seismic wave in seconds.

A more complete discussion of continuous seismic-reflection methods and techniques can be found in Haeni and Melvin (1984) and Haeni (1986).

A seismic-refraction survey was conducted on the ground surface. The seismic-refraction system consisted of a 12-channel seismograph, field computer, energy source and associated equipment, geophones, geophone cable, and surveying equipment. Geophone cables were laid on the ground surface perpendicular to the river using 50- or $100-\mathrm{ft}$ spacings for the geophones. The data collected were interpreted using a computer-modeling procedure based on a delay-time technique found in Scott (1977a, b) called SIPT2 V3.2. Haeni (1988) provides a more detailed discussion of seismic-refraction methods and techniques.

\section{Well Construction and Nomenclature}

Information from 483 municipal, industrial, and domestic wells in the Cedar River alluvial, glacial till, Devonian, and Silurian aquifers were compiled for location, geology, well construction, and depth, and were assigned a data-base identifier (Schnoebelen and Schulmeyer, 1996).

Sixty-seven observation wells were installed in the Cedar River alluvial, glacial till, and Devonian aquifers to provide information on hydrogeology, water levels, and water quality. Observation wells consisted of 54 small-diameter [0.1406-in. O.D. (outside diameter)] wells and 132 - and 4-in. O.D. wells.

The small-diameter wells were installed in the Cedar River alluvial and glacial till aquifers using $9 \mathrm{ft}$ of 1.25-in. O.D. diameter solid-stem augers to start the borehole. A hollow-stem drill rod, 0.875-in. O.D. with a sand point, was advanced into the ground by an electric hand-held hammer drill to desired depth. The drill rod contained 0.1406-in. O.D. Teflon tubing inside. The sand-point screen interval was 3-in. long and comprised of polyvinyl chloride (PVC) or stainless steel. The wells were capped with 1-in. diameter PVC pipe for a protective casing.

Thirteen 2- and 4-in. O.D. wells were installed in the Cedar River alluvial aquifer and in the Devonian aquifer. Nine observation wells were installed in the Cedar River alluvial aquifer using continuous-flight, hollow-stem augers and completed with 2- or 4-in. O.D. PVC casing and $2.5 \mathrm{ft}$ of PVC screen. Four observation wells [CRM-6 (site 986), CRM-7 (site 990), CRM-11 (site 994), and CRM-12 (site 995)] were installed in the Devonian aquifer using direct mud-rotary drilling. These observation wells penetrated the Devonian aquifer by 15 to $20 \mathrm{ft}$ at each location and were completed with 4-in. O.D. PVC casing and $5 \mathrm{ft}$ of PVC screen. The annulus around the screen and PVC casing was filled with a washed sand pack and capped with $5 \mathrm{ft}$ of bentonite seal to the top of the bedrock surface. The annulus was then filled with a bentonite/cement grout to land surface and capped with cement and a protective cover. Drill cuttings were collected about every $5 \mathrm{ft}$ for lithologic description during installation of the 2- and 4-in. O.D. wells.

Observation wells were developed by pumping three or four casing volumes of water to provide a representative water sample and water level. Observation and municipal wells were surveyed for vertical control and referenced to sea level and location (latitude and longitude) with a combination of a GPS (Ashtech Company, 1991) and conventional surveying techniques.

Observation wells were identified by a site name containing CRM (Cedar Rapids Municipal) as a prefix followed by a designated number (for example, CRM-7). The small-diameter wells were further designated by SD (small diameter) after the prefix (for example, CRM-SD-37). Clusters of observation wells were designated by a site name that included alpha characters to differentiate closely spaced sites (for example, CRM-SD-37A, CRM-SD-37B) (table 12, in "Supplemental Information" section).

\section{Hydrograph-Separation Analysis}

Hydrograph separation divides the streamflow into its component parts-overland runoff and ground-water discharge (base-flow discharge) (Sloto, 1991). Estimates of base-flow discharge to streams 
were calculated by hydrograph-separation analysis on streamflow data collected at the Cedar River at Cedar Rapids and Prairie Creek at Fairfax gaging station (fig. 1). A hydrograph-separation program (HYSEP) developed by the USGS (Sloto, 1991) was used to calculate base-flow discharge as a percentage of streamflow. RORA, a hydrograph-separation program developed by the USGS, determines a mathematical expression for recession of ground-water discharge and estimates mean ground-water recharge and discharge from streamflow records (Rutledge, 1993). RORA uses the recession-curve displacement method to estimate the recharge for each peak in the streamflow record (Rutledge, 1993). RORA was used to calculate base-flow discharge as a percentage of streamflow for selected streams with continuous records in small stream basins. These small stream basins are within a 50-mi radius of the model area and have similar hydrologic settings as the model area; therefore, RORA results provide representative base-flow discharge per square mile. The ground-water discharge per square mile of drainage basin is calculated:

$$
\begin{gathered}
{\left[\text { Mean streamflow }\left(\mathrm{ft}^{3} / \mathrm{s}\right)\right] *[\text { Base-flow index (dimensionless) }]} \\
\text { [Drainage area } \left.\left(\mathrm{mi}^{2}\right)\right]
\end{gathered}
$$

\section{Ground-Water Levels}

Ground-water levels were measured manually to the nearest $0.01 \mathrm{ft}$ from 182 observation, municipal, industrial, and private wells using a calibrated steel tape. Water levels measured in small-diameter wells were measured to the nearest $0.01 \mathrm{ft}$ using an electric tape. All water levels were measured according to USGS procedures (U.S. Geological Survey, 1977) and are reported in Schnoebelen and Schulmeyer (1996).

\section{Ground-Water Flow Model}

A modular, three-dimensional, finite-difference ground-water flow model was developed using the USGS MODFLOW program and used to simulate ground-water flow in the model area (McDonald and Harbaugh, 1988). The program simulates flow in three dimensions by using a block-centered, finite-difference approach that simultaneously solves a series of mathematical equations describing saturated ground-water flow. The finite-difference equations are solved using the preconditioned conjugate-gradient 2 (PCG2) method described by Hill (1990).

MODPATH is a particle-tracking, post-processing package developed to compute three-dimensional flow paths using output from MODFLOW (Pollock, 1989, 1994). Particle flow paths are computed by tracking hypothetical particles from one cell to the next until the particle reaches a boundary, an internal sink or source, or satisfies some other termination criterion (Pollock, $1989,1994)$. The data from MODPATH are graphically displayed using MODPATH-PLOT (Pollock, 1989, 1994). Input data for MODFLOW and MODPATH are entered using the preprocessor MFI, an interactive data-entry program for MODFLOW (Harbaugh, 1994).

\section{Multiprobe Monitoring}

Multiprobe instruments were used to continuously monitor ground-water levels or river stage and selected water-quality properties and constituents (specific conductance, $\mathrm{pH}$, water temperature, and dissolved oxygen) in selected municipal and observation wells at two intensive study sites in the Seminole Well Field and in the Cedar River (fig. 3). The multiprobe instrument recorded data at 15-minute intervals, and data were retrieved by field personnel every 2 to 4 weeks. When retrieval of data would be delayed for several months due to freezing temperatures, 30 - or 60 -minute recording intervals were used. The multiprobes were recalibrated after each data retrieval.

\section{Water-Quality Sampling}

Surface-water and ground-water samples were collected from October 1992 through March 1996 for analysis of major ions (calcium, magnesium, sodium, potassium, sulfate, chloride, and fluoride); nutrients (nitrite nitrogen, nitrite plus nitrate nitrogen, ammonia nitrogen, ammonia plus organic nitrogen, phosphorus, and orthophosphate); iron and manganese; dissolved organic carbon (DOC); and selected herbicides. Samples were analyzed at the USGS National WaterQuality Laboratory (NWQL) in Arvada, Colorado, following the procedures described by Fishman and Friedman (1989). Onsite measurements of specific conductance, $\mathrm{pH}$, water temperature, alkalinity, and dissolved oxygen were performed at the time of sample 
collection. Data are reported in Schnoebelen and Schulmeyer (1996).

Ground-water samples were collected after removing a minium of three well volumes of water with a peristaltic pump for the small-diameter observation wells or a portable submersible pump for the 2- and 4-in. observation wells. Municipal and industrial wells had permanently installed pumps and were sampled at the well head during normal operation of the well.

Surface- and ground-water samples were prepared, preserved, stored, and shipped according to procedures and requirements established by the NWQL. Water samples collected for dissolved constituent analysis were first filtered through a 0.45 -micrometer pore-size cellulose filter in a polycarbonate-filter plate. Water samples collected for calcium, magnesium, sodium, manganese, and iron analysis were preserved with nitric acid, whereas samples for alkalinity, DOC, nutrients, chloride, fluoride, and sulfate analysis were untreated. Water samples were stored on ice during transport from the field to the NWQL. The submersible pump, peristaltic pump, filter plates, and Teflon tubing were cleaned with a nonphosphate laboratory detergent, rinsed with organic-free deionized water, and allowed to air dry before each day's sample collection. The equipment was then rinsed with organic-free deionized water between samples. Tubing for the peristaltic pump and filter plates also were rinsed at the end of the day with a solution of 5-percent hydrochloric acid. Filter plates were autoclaved before sampling.

Approximately 10 percent of the surface- and ground-water samples were quality-control (QC) samples - a mixture of blank and replicate samples. Blank samples were organic-free deionized water that has passed through the pump, filter plate, and filter as if they were a surface- or ground-water sample and were used to verify cleanliness of sampling equipment and technique. Analytical results for herbicide blank samples were less than the minimum reporting level (MRL) of $0.05 \mu \mathrm{g} / \mathrm{L}$. Analytical results for nutrient blank samples typically were less than the MRL of $0.05 \mathrm{mg} / \mathrm{L}$, with the exception of a nitrite plus nitrate nitrogen concentration of $0.06 \mathrm{mg} / \mathrm{L}$ reported for one blank sample. Analytical results for major ion blank samples were generally less than the MRL for a particular constituent, although calcium, chloride, and fluoride showed small concentrations of $0.05,0.30$, and $0.10 \mathrm{mg} / \mathrm{L}$, respectively. The replicate samples were collected simultaneously with surface- and groundwater samples to help define the possible deviations in data handling or the variability in analytical results. The analytical results of the blank and replicate samples indicate minimal variability in analytical results and verify that the sample-collection and handling procedures were appropriate.

Ground-water samples were collected during April 1995 for analysis of environmental isotopes. Oxygen and hydrogen isotopes, ${ }^{18} \mathrm{O} /{ }^{16} \mathrm{O}$ and ${ }^{2} \mathrm{H} /{ }^{1} \mathrm{H}$, and tritium $\left({ }^{3} \mathrm{H}\right)$ were analyzed through the NWQL. Tritium analysis has a MRL of $0.3 \mathrm{pCi} / \mathrm{L}$.

\section{HYDROGEOLOGY}

\section{Geology}

Surface and subsurface geology affect the occurrence, distribution, and movement of ground water. The geologic units of interest in the model area include shale, dolomite, and limestone of the Ordovician System; dolomite of the Silurian System; shale, dolomite, and limestone of the Devonian System; and unconsolidated deposits of the Quaternary System that include buried-channel deposits, glacial till, loess and eolian sand, and alluvium (sand, gravel, clay, and silt). A hydrogeologic section constructed from drillers' log information obtained from the Iowa Department of Natural Resources, Geological Survey Bureau, shows the geology in the model area (fig. 6).

The Ordovician System includes green dolomitic shale, and medium- to coarse-grained dolomite and limestone of the Maquoketa Formation. The Maquoketa Formation underlies the Silurian System in the model area.

The Silurian System includes dolomite of the Mosalem, Tete des Morts, Blanding, Hopkinton, Scotch Grove, and Gower Formations (table 1) (Wahl and Bunker, 1986, p. 15). Thickness of the Silurian System ranges from less than $150 \mathrm{ft}$ to more than $350 \mathrm{ft}$ in Linn County (Wahl and Bunker, 1986, p. 15). In Linn County, the Silurian System is exposed at land surface along the Wapsipinicon River in the northeast and along the Cedar River in the southeast (Wahl and Bunker, 1986, p. 36). Within the model area the Devonian and Silurian Systems occur as the bedrock surface in a buried channel where a preglacial river eroded through the overlying strata to form a preglacial river valley (fig. 6).

The Devonian System includes the Bertram, Otis, Wapsipinicon, and Cedar Valley Formations in the 


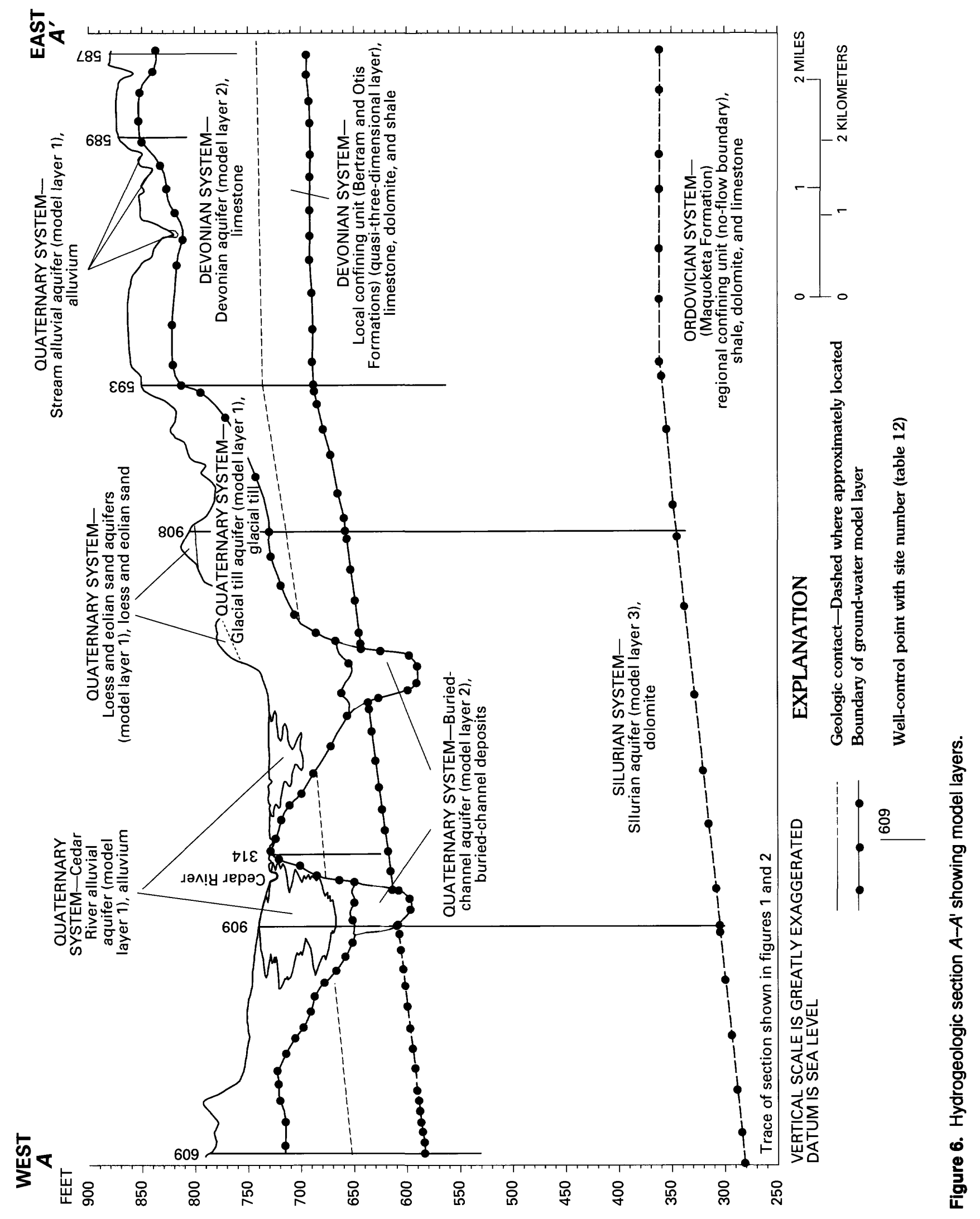


Table 1. Geologic and hydrogeologic units in model area, range of hydraulic conductivity, and equivalent model layer [f $/$ d, feet per day; --, no data]

\begin{tabular}{|c|c|c|c|c|}
\hline System & Geologlc unit & Hydrogeologic unit & $\begin{array}{c}\text { Range of } \\
\text { hydraulic } \\
\text { conductlvity } \\
\text { (ft/d) }\end{array}$ & $\begin{array}{l}\text { Equlvalent } \\
\text { layer in } \\
\text { dlgltal } \\
\text { ground-water } \\
\text { flow model }\end{array}$ \\
\hline \multirow[t]{6}{*}{ Quaternary } & Cedar River alluvium & Cedar River alluvial aquifer & $1_{21.0-315.0}$ & 1 \\
\hline & Stream alluvium & Stream alluvial aquifer & $1_{28.1}$ & 1 \\
\hline & Loess & Loess aquifers & $1,28.5 \times 10^{-5}-2.83$ & 1 \\
\hline & Eolian sand & Eolian sand aquifer & $1,2.0-20.0$ & 1 \\
\hline & Glacial till & Glacial till aquifer & ${ }^{2} 5.0 \times 10^{-6}-0.85$ & 1 \\
\hline & Buried-channel deposits & Buried-channel aquifer & -- & 2 \\
\hline \multirow[t]{2}{*}{ Devonian } & $\begin{array}{l}\text { Cedar Valley Formation } \\
\text { Wapsipinicon Formation }\end{array}$ & Devonian aquifer & ${ }^{3} 4.0-294.0$ & 2 \\
\hline & $\begin{array}{l}\text { Otis Formation } \\
\text { Bertram Formation }\end{array}$ & Local confining unit & - & -- \\
\hline Silurian & $\begin{array}{l}\text { Gower Formation } \\
\text { Scotch Grove Formation } \\
\text { Hopkinton Formation } \\
\text { Blanding Formation } \\
\text { Tete des Morts Formation } \\
\text { Mosalem Formation }\end{array}$ & Silurian aquifer & $48.0-18.0$ & 3 \\
\hline Ordovician & Maquoketa Formation & Regional confining unit & -- & $\begin{array}{l}\text { Basal } \\
\text { (no-flow } \\
\text { boundary) }\end{array}$ \\
\hline
\end{tabular}

\footnotetext{
${ }^{1}$ Kunkle (1968), Freeze and Cherry (1979), and Schulmeyer (1995).

${ }^{2}$ Kunkle (1968), Hallberg (1980) and W. Simpkins (Iowa State University, written commun., 1994).

${ }^{3}$ Libra and Hallberg (1985).

${ }^{4}$ Hansen (1970) and ground-water data for 1941 on file with U.S. Geological Survey, lowa City, Iowa.
}

model area (table 1). The Bertram Formation is comprised of limestone, dolomite, and interbedded shale, and the Otis Formation is comprised of dense limestone and dolomite (Wahl and Bunker, 1986, p. 37). Thickness of the Bertram Formation ranges from 0 to $75 \mathrm{ft}$ (Bunker and others, 1985, p. 42), and thickness of the Otis Formation ranges from 0 to $50 \mathrm{ft}$ (Bunker and others, 1985, p. 45). The Wapsipinicon and Cedar Valley Formations principally are fractured limestone that have been deeply weathered where exposed in the bedrock surface and together have a maximum thickness of $124 \mathrm{ft}$ (Wahl and Bunker, 1986, p. 42). In parts of the model area, the Wapsipinicon and Cedar Valley Formations were removed by a preglacial river, and the Bertram and Otis Formations form the bedrock surface. Erosion by this preglacial river locally removed rocks of the Devonian and Silurian Systems forming a preglacial river channel (fig. 6).

The unconsolidated deposits of the Quaternary System irregularly mantle the bedrock surface in the model area and are delineated on a map of surficial geology by Hallberg and others (1978, p. 32) (fig. 7). Buried-channel deposits occur in a preglacial river valley and are comprised of silt, fine-to-coarse sand, and coarse, angular gravel that is capped by about $40 \mathrm{ft}$ of a gray, silty clay with some sand and gravel. Results of the continuous seismic-reflection and seismic-refraction investigations indicate a depth to bedrock and a maximum thickness of $175 \mathrm{ft}$ in an area $1.75 \mathrm{mi}$ southeast of Palo (Schnoebelen and Schulmeyer, 1996) that corresponds to the location of a buried channel reported by Hansen (1970). The continuous seis- 


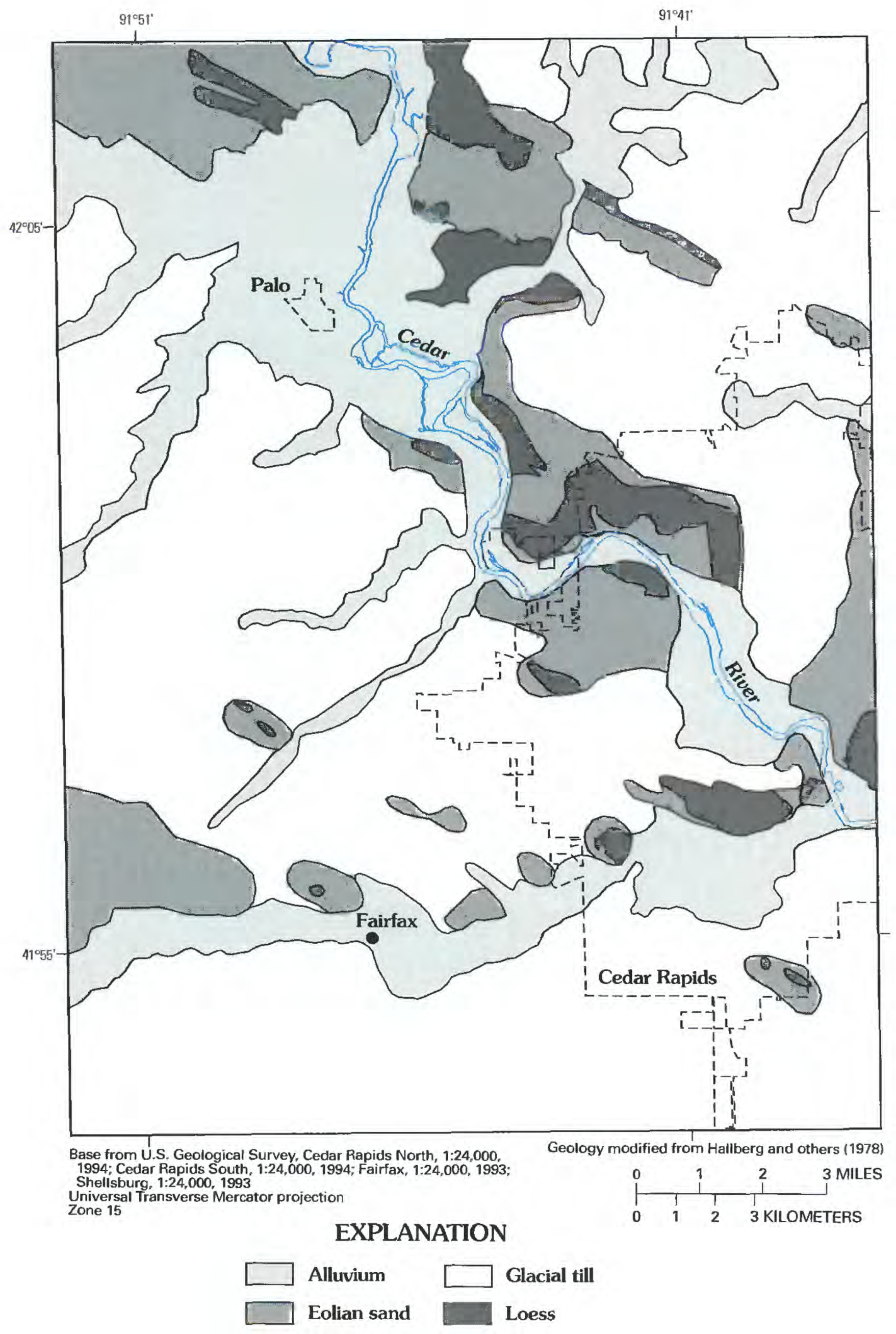

Figure 7. Surficial geology of model area. 
mic-reflection profile traversed the buried channel and indicated a depth to bedrock of $128 \mathrm{ft}$ under the Cedar River. A seismic-refraction survey conducted near this location indicated a depth to bedrock of $136 \mathrm{ft}$, and an observation well, CRM-13 (site 996), drilled $1 \mathrm{mi}$ south of Palo, indicated a depth to bedrock of $145 \mathrm{ft}$. Drill cuttings from the observation well indicated fine sand to gravel from land surface to a depth of $76 \mathrm{ft}$; glacial till, 76-115 ft; coarse sand to medium gravel, $115-140 \mathrm{ft}$; and silty clay, $140-145 \mathrm{ft}$.

Glacial till consists of heterogenous rock material predominantly comprised of dense yellow or blue-gray clay with small amounts of sand, pebbles, and boulders. Thickness of the glacial till ranges from a few feet to more than $300 \mathrm{ft}$ (Hansen, 1970, p. 19). The glacial till is interspersed with paleosols and fluvial material deposited by glacial meltwaters or interglacial streams that form sorted, lenticular, and sheet-like deposits of sand, gravel, silt, and clay (Hansen, 1970, p. 19). Glacial till is typically divided into fractured weathered till and unfractured unweathered till. Weathered portions of the glacial till exhibit joints or fractures. The unfractured, unweathered till changes gradationally upward to a fractured weathered till near the surface where highly fractured zones are common. Fractures are predominately vertical and generally reach to depths of 15-30 ft in weathered glacial tills (Keller and others, 1986). Fractures can be limited to individual till layers deposited during separate glacial episodes. Locally, fractures can interconnect several layers.

Loess and eolian sand are fine-grained deposits of wind-carried rock particles that were produced by the grinding effect of the glaciers (Anderson, 1983). The loess and eolian sand deposits generally are located on tops of hills and ridges and are typically oriented in a northwest-to-southeast direction. The thickness of the loess and eolian sand deposits is generally about $30 \mathrm{ft}$.

Alluvium in the model area consists of the Cedar River alluvium and stream alluvium. The Cedar River alluvium is comprised of a fining-upward sequence of sand and gravel with minor amounts of silt and clay formed by the lateral deposition of sediment by the Cedar River. As the river channel meanders across the flood plain, sand and gravel deposits are built up as point bars and a fining-upward sequence of grain size results. Stream alluvium occurs along streambeds of tributaries to the Cedar River. Stream alluvium is comprised of sand, gravel, silt, and clay. The unit has not been extensively studied, and the range in thickness is unknown.

The Cedar River alluvium in the model area varies from 5 to $95 \mathrm{ft}$ thick (Hansen, 1970, p. 31). Results of the continuous seismic-reflection and seismic-refraction investigations in and near the Seminole Well Field indicate that the Cedar River alluvium varies from 40 to $96 \mathrm{ft}$ thick (Schnoebelen and Schulmeyer, 1996). The alluvium thins with increasing distance from the river towards the uplands area where the glacial till and loess become the predominant unconsolidated deposits. Geologic data from the Iowa Department of Transportation indicate that the Cedar River alluvium is about $30 \mathrm{ft}$ thick at Blair's Ferry Road bridge near Palo (fig. 2) and overlies glacial till. The glacial till overlies either limestone of the Devonian System or buried-channel deposits. This sequence of deposits, alluvium covering glacial till, is assumed to extend north from Blair's Ferry Road along the Cedar River within the model area. Geologic data from the Iowa Department of Transportation collected near the I-380 bridge across the Cedar River (fig. 2) indicate limestone of the Devonian System is exposed in the streambed, with glacial till present along the banks of the Cedar River (Hallberg and others, 1978). Near the I-380 bridge, there may be thin deposits of alluvium that overlie the glacial till in the Cedar River flood plain. About $6 \mathrm{mi}$ southeast of Cedar Rapids along the Cedar River at a previous study site (Squillace and others, 1996) the Cedar River alluvium is 30 to $40 \mathrm{ft}$ thick overlying $\mathbf{3 0}$ to $40 \mathrm{ft}$ of glacial till that overlies Devonian bedrock. This sequence of deposits, alluvium covering glacial till, is assumed to extend south through the model area along the Cedar River from the I-380 bridge to the model boundary.

\section{Hydrogeologic Units}

Hydrogeologic units in the model area include the Cedar River alluvial aquifer, stream alluvial aquifers, loess and eolian sand aquifers, glacial till aquifers, a buried-channel aquifer, Devonian aquifer and the local confining unit comprised of limestone, dolomite, and shale of the Otis and Bertram Formations, Silurian aquifer, and the regional confining unit comprised of shale, limestone, and dolomite of the Maquoketa Formation. Water-bearing characteristics and hydraulic properties, such as transmissivity, specific capacity, hydraulic conductivity, and porosity, are discussed. 


\section{Cedar River Alluvial Aquifer}

The Cedar River alluvial aquifer is comprised of sand, gravel, and minor amounts of clay and silt of the Cedar River alluvium. An approximate transmissivity of $20,000 \mathrm{ft}^{2} / \mathrm{d}$ and storage coefficient of 0.1 were determined for the Cedar River alluvial aquifer in the East and West Well Fields (Hansen, 1970). Specific-capacity data from 46 of the municipal wells were used to calculate transmissivity for the Cedar River alluvial aquifer using a modified Theis equation (Heath, 1987). Calculated transmissivity ranged from 1,543 to $19,240 \mathrm{ft}^{2} / \mathrm{d}$ (Schulmeyer, 1995). The large range in transmissivity determined from specific capacity might not be representative of the hydraulic characteristics of the aquifer because specific capacity also depends on construction of the well. Hydraulic conductivities of 21.3 to $315.2 \mathrm{ft} / \mathrm{d}$ are calculated by dividing the transmissivity determined from specific capacity data by the thickness of saturated material (Schulmeyer, 1995). Hydraulic conductivity determined from single-well hydraulic tests performed on the Cedar River alluvial aquifer south of Cedar Rapids ranged from 2.0 to $174.0 \mathrm{ft} / \mathrm{d}$ (Squillace and others, 1996). The hydraulic conductivity for sand and gravel deposits generally ranges from 2.8 to $2,834 \mathrm{ft} / \mathrm{d}$ (Freeze and Cherry, 1979). Porosity values for the Cedar River alluvial aquifer were estimated from Todd (1980) to range from 0.34 to 0.39 .

Wells pumping from the Cedar River alluvial aquifer can cause infiltration of water from the Cedar River. The rate of infiltration is dependent on the hydraulic conductivity of the aquifer, the hydraulic gradient between the river and the aquifer, and the infiltration capacity of the riverbed materials (Hansen, 1970, p. 34). Traveltimes of water recharging the alluvial aquifer from the Cedar River at Seminole 10 (site 40) ranged from 7 to 17 days as determined by indirect means (Schulmeyer, 1995).

\section{Stream Alluvial, Loess, and Eolian Sand Aquifers}

Stream alluvium and discontinuous deposits of loess and eolian sand that overlie the glacial till in the model area are of little importance as aquifers and have not been extensively studied. The stream alluvial aquifers occur along small streams tributary to the Cedar River. Loess and eolian sand deposits can store minor amounts of water and are referred to as the loess and eolian sand aquifers in this report. A hydraulic conductivity of $28.1 \mathrm{ft} / \mathrm{d}$ for stream alluvium is reported by Kunkle (1968). Hydraulic conductivity measured
$2.04 \mathrm{ft} / \mathrm{d}$ for eolian sand and $1.2 \times 10^{-3} \mathrm{ft} / \mathrm{d}$ for loess (Hallberg, 1980). Porosity values for loess (0.49) and eolian sand (0.43) were estimated from Todd (1980).

\section{Glacial Till Aquifer}

The glacial till aquifer serves as a minor source of water in the model area. The water-bearing characteristics depend on the random distribution of sand and gravel lenses in the glacial till and the network of fractures commonly found in weathered portions. These fractures can form a network of interconnections enhancing the capability for ground-water flow (Freeze and Cherry, 1979, p. 152). Hydraulic conductivity from field tests on unfractured till may be 1 to 3 orders of magnitude greater than tests performed in the laboratory (Freeze and Cherry, 1979, p. 152). Weathered till and fluvial-glacial sand and gravel have larger hydraulic conductivities than unweathered till. Hydraulic conductivities of $8.5 \times 10^{-3} \mathrm{ft} / \mathrm{d}$ for weathered till and $5.7 \times 10^{-5} \mathrm{ft} / \mathrm{d}$ for unweathered till have been reported (W. Simpkins, Iowa State University, oral commun., 1994). Average vertical leakance through the glacial till was estimated at $4.0 \times 10^{-4} \mathrm{ft} / \mathrm{d}$ in an area $40 \mathrm{mi}$ northwest of the model area (Kunkle, 1968, p. O12). Hallberg (1980) reported vertical hydraulic conductivities for glacial till ranging from $5.3 \times 10^{-6}$ to $1.1 \times 10^{-4} \mathrm{ft} / \mathrm{d}$ as determined from laboratory tests. A porosity of 0.31 was estimated for glacial till (Todd, 1980).

\section{Buried-Channel Aquifer}

A buried-channel aquifer underlies the glacial till and Cedar River alluvial aquifers in some parts of the model area. The Cedar River alluvial aquifer is in hydraulic connection with the buried-channel aquifer in some areas, but generally the two aquifers are separated by glacial till (Hansen, 1970, p. 38). Hansen (1970) reports a yield of $350 \mathrm{gal} / \mathrm{min}$ from a well completed in the buried-channel aquifer. A porosity for the buried-channel aquifer was estimated at 0.39 (Todd, 1980).

\section{Devonian Aquifer, Local Confining Unit, and Silurian Aquifer}

Limestone of the Wapsipinicon and Cedar Valley Formations forms the Devonian aquifer. Shale, limestone, and dolomite of the Bertram and Otis Formations form a local confining unit, present throughout most of the model area, that separates the Devonian and Silurian aquifers (Wahl and Bunker, 1986, p. 37). 
Dolomite of the Silurian System forms the Silurian aquifer.

The Devonian aquifer underlies unconsolidated material in most of the model area. Areas where the Devonian aquifer is at the bedrock surface and is extensively weathered can yield more water than areas that have not been weathered (Wahl and Bunker, 1986, p. 42). Weathering and dissolution of rock increases the number and size of fractures and joints and their interconnections, thus increasing water-yielding potential. Erosion has removed parts of the Devonian aquifer in the model area, and erosional remnants occur as bedrock highs (Wahl and Bunker, 1986). Hydraulic conductivity values for the Devonian aquifer, determined in an area north of the model area, range from 4 to $294 \mathrm{ft} / \mathrm{d}$ (Libra and Hallberg, 1985).

A local confining unit comprised of shale, limestone, and dolomite of the Bertram and Otis Formations restricts flow between the Devonian and Silurian aquifers. Where the Bertram and Otis Formations are at the bedrock surface and have been significantly weathered, the local confining unit can have hydrologic properties similar to the Devonian aquifer. The portion of the Bertram and Otis Formations that has been exposed at the bedrock surface and has weathered, which generally is within the preglacial valley, is referred to in this report as the weathered portion of the confining unit. A porosity of 0.06 was estimated for the local confining unit and 0.16 for the weathered portion of the local confining unit (Todd, 1980).

The Silurian aquifer underlies the local confining unit, except where the Silurian aquifer forms the bedrock surface in the preglacial river valley and underlies buried-channel deposits. The hydraulic heads for adjacent wells completed in the Silurian aquifer and the buried-channel aquifer are similar and indicate hydraulic connection between the aquifers (Hansen, 1970, p. 38). Transmissivity for the Silurian aquifer of about $1,340 \mathrm{ft}^{2} / \mathrm{d}$ and hydraulic conductivity of about $6.1 \mathrm{ft} / \mathrm{d}$ were calculated from a pumping test (Hansen, 1970).

Recovery data from a pumping test conducted in 1941 on Marion City Well 1 (located $0.75 \mathrm{mi}$ east of the model area in the town of Marion, fig. 1) were used to calculate a transmissivity of $25,000 \mathrm{ft}^{2} / \mathrm{d}$ and a hydraulic conductivity of 8.7 to $18.1 \mathrm{ft} / \mathrm{d}$ (1941 ground-water data on file with U.S. Geological Survey, Iowa City, Iowa).

Many domestic and industrial wells in eastern Iowa are open to both the Devonian and Silurian aquifers, and these aquifers are often referred to as a single unit in the literature. In this report, the aquifers are referred to as the Devonian and Silurian aquifers where distinction between the two cannot be made. The water-yielding characteristics of the Devonian and Silurian aquifers are a result of joints, fractures, solution cavities, and bedding planes in the rock. A porosity of 0.26 was estimated for the limestone and dolomite that comprose the Devonian and Silurian aquifers (Todd, 1980).

\section{Regional Confining Unit}

Shale, limestone, and dolomite of the Maquoketa Formation underlie the Silurian aquifer and form a regional confining unit in the model area and in eastern Iowa (table 1). The low-permeability unit restricts the flow of water and is not known to yield substantial quantities of water to wells (Hansen, 1970, p. 12).

\section{Description of Ground-Water Flow in the Hydrologic Setting}

Local ground-water flow systems can form in humid regions where surface topography is well defined, causing undulations in the water table (Fetter, 1994, p. 279). The local ground-water flow system has a recharge area at a topographic high and a discharge area at an adjacent low within a particular surfacedrainage basin. Where the water table of the local ground-water flow system intercepts land surface, the ground-water flow system will discharge as a stream, seep, or spring. Base-flow discharge to the stream occupying that basin would be the result of contributions by a local ground-water flow system (Kunkle, 1968, p. O9). The Cedar River alluvial, glacial till, and stream alluvial aquifers are the primary hydrogeologic units of the local ground-water flow systems in the model area. Unweathered glacial till could act as a confining unit restricting the downward flow of water from the local ground-water flow system to the deeper intermediate and regional ground-water flow systems (Kunkle, 1968, p. O9).

Intermediate ground-water flow systems have at least one local ground-water flow system between the recharge and discharge areas (Fetter, 1994, p. 281). The primary hydrogeologic units of the intermediate ground-water flow systems in the model area could be made up of the Cedar River alluvial, glacial till, and Devonian aquifers. The local confining unit, Bertram and Otis Formations, restricts downward ground-water 
flow from the intermediate to the regional groundwater flow system.

Regional ground-water flow systems have recharge areas at a basin divide and discharge areas at the valley bottoms (Fetter, 1994, p. 281). The primary hydrogeologic units of the regional ground-water flow system in the model area include the buried-channel and Silurian aquifers. Regional ground-water flow systems associated with hydrogeologic units underlying the regional confining unit (Maquoketa Formation) are not discussed in this report.

\section{Surface-Water and Ground-Water Interaction}

Where a stream channel is in direct contact with an unconfined aquifer, the stream can recharge the aquifer or receive discharge from the aquifer depending on the hydraulic-head gradient between the stream and the aquifer (Todd, 1980). During periods of flooding, the stream stage is higher than the water table in the adjacent aquifer, and surface water infiltrates into the aquifer. Bank storage refers to water that has infiltrated into the banks of a stream channel when the stage of the stream rises above the water table in the streambanks, then returns to the channel as seepage when the stage falls below the water table (Langbein and Iseri, 1960). Kunkle (1968) calculated that about 45 percent of ground-water discharge from the Cedar River alluvial aquifer to the Cedar River was bank storage and that bank storage accounted for about 40 percent of base-flow discharge in a small tributary of the Cedar River located $40 \mathrm{mi}$ northwest of the model area.

Hydrograph-separation analysis was performed on streamflow data collected at the Cedar River at Cedar Rapids and Prairie Creek at Fairfax gaging stations (fig. 1). Using the HYSEP computer program (Sloto, 1991), the base-flow discharge of the Cedar River was estimated to be about 69.5 percent of mean streamflow or $0.48\left(\mathrm{ft}^{3} / \mathrm{s}\right) / \mathrm{mi}^{2}$ of drainage area, and of Prairie Creek (fig. 1) at $0.39\left(\mathrm{ft}^{3} / \mathrm{s}\right) / \mathrm{mi}^{2}$ or 58.1 percent of streamflow using the sliding-interval method. The computer program RORA (Rutledge, 1993) calculated the base-flow discharge as a percentage of mean streamflow for Prairie Creek (fig. 1) at 58.6 percent of mean streamflow. Similar results for base-flow discharge as a percentage of streamflow were determined by HYSEP and RORA analysis. A representative base-flow discharge per square mile was estimated from RORA analysis for five smaller stream basins located within a 50-mi radius of the model area that are in similar hydrologic settings as the model area. Calcu- lated base-flow discharge ranged from 0.38 to 0.47 $\left(\mathrm{ft}^{3} / \mathrm{s}\right) / \mathrm{mi}^{2}$, with a mean of $0.44\left(\mathrm{ft}^{3} / \mathrm{s}\right) / \mathrm{mi}^{2}$ (table 2$)$.

Recharge rates determined by RORA for the Prairie Creek Basin and the five smaller stream basins include both precipitation and runoff infiltration (Rutledge, 1993). A ground-water recharge rate of $6.9 \mathrm{in} / \mathrm{yr}$ was calculated for the Prairie Creek Basin, and ground-water recharge rates for the five smaller stream basins ranged from 6.8 to $7.8 \mathrm{in} . / \mathrm{yr}$.

\section{Ground-Water Flow In the Cedar River Alluvial Aquifer}

Recharge to the Cedar River alluvial aquifer occurs as infiltration of precipitation, infiltration of runoff from adjacent upland areas, leakage from adjacent aquifers, and leakage from the Cedar River that includes bank storage and induced infiltration caused by pumping from municipal water-supply wells. The Cedar River alluvial aquifer receives an adequate amount of recharge from precipitation to maintain the water table above river stage (Hansen, 1970, p. 34). When the river stage is lower than the water table, the aquifer discharges to the river. The Cedar River can receive as much as 80 percent of its annual discharge from ground-water contributions (Squillace and others, 1993).

Pumping from municipal water-supply wells is an important component of ground-water discharge from the Cedar River alluvial aquifer in the model area. Withdrawal of water from a well causes a decline of the water table near the well and forms a cone of depression. If the cone of depression intercepts a stream, induced infiltration of surface water to the alluvial aquifer can occur. A low-head dam located downstream from the East Well Field is designed to maintain a minimum river stage (pool elevation) of $717.9 \mathrm{ft}(\mathrm{M}$. Lynch, City of Cedar Rapids Water Department, oral commun., 1994) and to create a pool area on the Cedar River (fig. 2). The pool area acts as a source of recharge to the Cedar River alluvial aquifer in the East and West Well Fields.

\section{Ground-Water Flow in the Devonian and Silurian Aquifers}

Recharge of the ground-water flow system in the Devonian and Silurian aquifers comes from vertical infiltration of precipitation and leakage from adjacent aquifers (Hansen, 1970). Where Devonian and Silurian aquifers are at or near the ground surface, such as in east and northeast Linn County, recharge can occur 
Tabie 2. Calculated base-flow discharge of selected streams near model area [station number, assigned by the U.S. Geological Survey to locations where streamflow is measured on a regular basis-the first two digits identify the major basin in which the stream is located, the remaining six digits identify the relative locations; $\mathrm{mi}^{2}$, square miles; $\mathrm{ft}^{3} / \mathrm{s}$, cubic feet per second; $\left(\mathrm{ft}^{3} / \mathrm{s}\right) / \mathrm{mi}^{2}$, cubic feet per second per square mile]

\begin{tabular}{|c|c|c|c|c|c|}
\hline Station name & $\begin{array}{l}\text { Station } \\
\text { number }\end{array}$ & $\begin{array}{c}\text { Drainage } \\
\text { area } \\
\left(\mathbf{m i}^{\mathbf{2}}\right)\end{array}$ & $\begin{array}{c}\text { Base-fiow } \\
\text { discharge, } \\
\text { in percent } \\
\text { (base-fiow } \\
\text { index) }{ }^{2}\end{array}$ & $\begin{array}{c}\text { Mean stream- } \\
\text { fiow } \\
\text { discharge }^{2} \\
\left(\mathrm{ft}^{3} / \mathrm{s}\right)\end{array}$ & $\begin{array}{c}\text { Base-fiow } \\
\text { discharge } \\
\text { per square } \\
\text { mile } \\
{\left[\left(\mathrm{ft}^{3} / \mathrm{s}\right) / \mathrm{mi}^{2}\right]}\end{array}$ \\
\hline Big Bear Creek at Ladora, Iowa & 05453000 & 189.0 & 58.7 & 149.88 & 0.47 \\
\hline Black Hawk Creek at Hudson, Iowa & 05463500 & 303.0 & 65.0 & 220.64 & .47 \\
\hline Rapid Creek near Iowa City, Iowa & 05454000 & 25.3 & 54.5 & 20.01 & .43 \\
\hline $\begin{array}{l}\text { South Branch Ralston Creek at Iowa } \\
\text { City, Iowa }\end{array}$ & 05455010 & 2.94 & 42.9 & 2.60 & .38 \\
\hline Walnut Creek near Hartwick, Iowa & 05452200 & 70.9 & 57.6 & 56.39 & .46 \\
\hline Prairie Creek at Fairfax, Iowa & 05464640 & 178.0 & 58.6 & 130.28 & .43 \\
\hline Cedar River at Cedar Rapids, Iowa & 05464500 & 6,510 & 69.5 & $3,242.06$ & .35 \\
\hline
\end{tabular}

directly as infiltration of precipitation (Hansen, 1970, p. 26). Recharge to the Devonian and Silurian aquifers also occurs as leakage from overlying alluvial, glacial till, loess and eolian sand, or buried-channel aquifers (Kunkle, 1968, p. 11; Hansen, 1970, p. 26). Hansen (1970) calculated recharge to the Devonian and Silurian aquifers by seepage through the overlying glacial till at $8.9 \times 10^{-2}\left(\mathrm{ft}^{3} / \mathrm{s}\right) / \mathrm{mi}^{2}$. The loess along Four Mile Creek in Tama County to the west of the study area receives $2.1 \mathrm{in}$. of recharge annually, and glacial till receives $1.4 \mathrm{in}$. of recharge as vertical leakage from the overlying loess (Kunkle, 1968). Wahl and Bunker (1986) determined that recharge or discharge of the Silurian aquifer could occur in areas covered by less than $50 \mathrm{ft}$ of weathered, fractured, or disturbed deposits.

Discharge from the Devonian and Silurian aquifers occurs as leakage to adjacent aquifers, seepage to streams or rivers (principally the Cedar River), seeps or springs, and pumpage from wells. Ground-water discharge from bedrock aquifers to streams was about $3.2 \mathrm{ft}^{3} / \mathrm{d}$ for the Wolf Creek Basin in northeast Tama County (Kunkle, 1965, p. D209). Ground-water pumping from the Devonian and Silurian aquifers in the Cedar Rapids area has caused a cone of depression in the potentiometric surface under the city of Cedar Rapids (fig. 8). The center of this cone of depression is located southeast of the municipal well fields along the river near the center of the downtown area. Hansen $(1970$, p. 46$)$ reports that the potentiometric surface was $2 \mathrm{ft}$ above land surface at an altitude of $725 \mathrm{ft}$ prior to 1930 . By the 1930 's, the potentiometric surface had declined to about $700 \mathrm{ft}$, and by 1966 to about $620 \mathrm{ft}$ (Hansen, 1970, p. 46). A water level of $581 \mathrm{ft}$ was measured in the Pepsi-Cola well (site 328, fig. 2) in September 1993.

Ground-water levels were measured during 1993-96 in observation wells CRM-6 (site 986, fig. 3), CRM-7 (site 990, fig. 3), CRM-11 (site 994, fig. 5), and CRM-12 (site 995, fig. 4) that partially penetrate the Devonian aquifer (table 3). These four wells are located outside the cone of depression beneath the city of Cedar Rapids. The hydraulic head in the Devonian aquifer is higher than the hydraulic head in the Cedar River alluvial aquifer at three of the sites. This implies that water from the Devonian aquifer could be recharging the Cedar River alluvial aquifer within the municipal well fields (Hansen, 1970; Schulmeyer, 1995). The hydraulic head in the Cedar River alluvial aquifer is higher than that in the Devonian aquifer near municipal well Seminole 1 (site 31), which either indicates that the Cedar River alluvial aquifer is recharging the Devonian aquifer (table 3 ) or that the Devonian aquifer, at this location, is less permeable and slow to recover after pumping of the Cedar River alluvial aquifer by the municipal well.

A potentiometric-surface map was constructed from water levels measured from June through August 1993 in the Devonian and Silurian aquifers (Schnoe- 


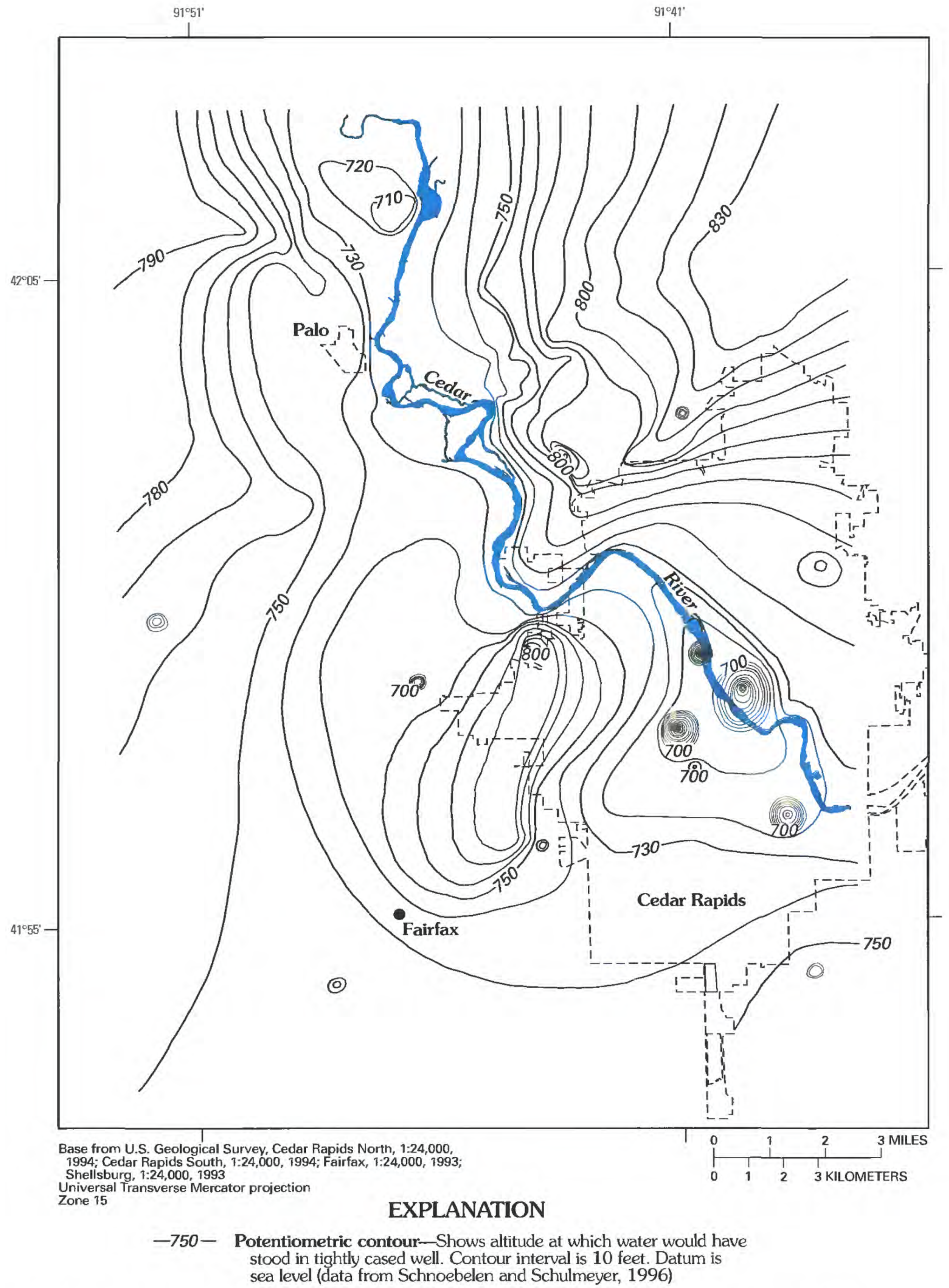

Figure 8. Potentiometric surface of the Devonian and Siiurian aquifers, June through August 1993. 


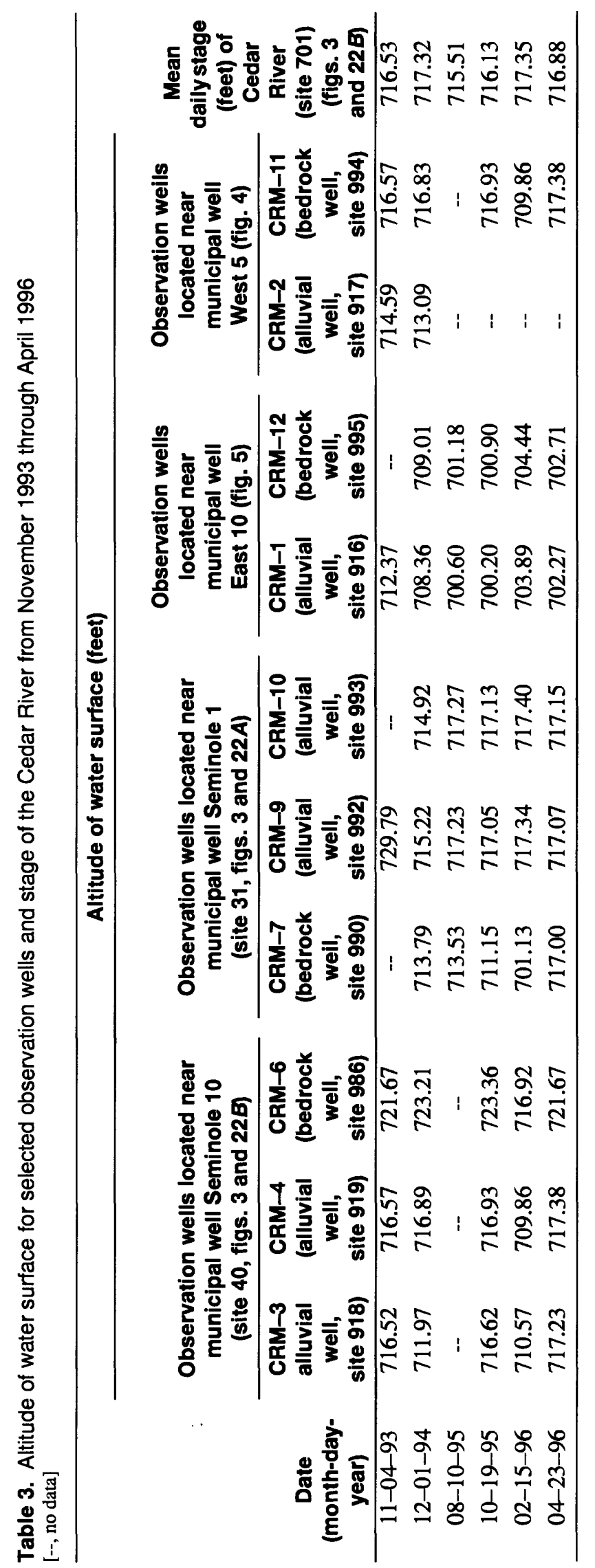


belen and Schulmeyer, 1996) (fig. 8). The map represents an approximate potentiometric surface of the Devonian and Silurian aquifers because water levels were measured in wells that are open to the Devonian, the Silurian, or both aquifers. The regional groundwater flow direction is generally toward the Cedar River. Smaller tributaries to the Cedar River appear to have little effect on the regional potentiometric surface of the Devonian and Silurian aquifers. Only a few wells were measured for this study within the cone of depression that occurs beneath the city of Cedar Rapids.

\section{GROUND-WATER FLOW SIMULATION}

The USGS modular, three-dimensional, finite-difference ground-water flow model (MODFLOW) was used to simulate local, intermediate, and regional ground-water flow systems in the $231-\mathrm{mi}^{2}$ modeled area near Cedar Rapids, Iowa (fig. 1). The constructed three-layer model was used to determine the sources of water to the Cedar River alluvial aquifer presuming equilibrium conditions. December 1994 hydrologic conditions were assumed to be an acceptable initial condition for the model area. The long-term average water level for eight bedrock wells in the groundwater-level monitoring network in the model area, a cooperative program with the Iowa Department of Natural Resources (Geological Survey Bureau), were comparable to the December 1994 measured values (Schnoebelen and Schulmeyer, 1996). Annual ground-water withdrawals by pumping from the Devonian and Silurian aquifers did not vary significantly. Observation wells in the Cedar River alluvial aquifer, Devonian aquifer, and Silurian aquifer were measured during December 1994 (Schnoebelen and Schulmeyer, 1996), during a period of little or no precipitation. The December 1994 mean monthly flow in the Cedar River was similar to its mean annual flow of $3,670 \mathrm{ft}^{3} / \mathrm{s}$ for the period of record, 1903-94 (May and others, 1994).

\section{Model Description and Assumptions}

The three-layer steady-state model was used to simulate the ground-water flow system in the model area. The model used a grid of 184 rows by $140 \mathrm{col}-$ umns with individual cell dimensions of $500 \mathrm{ft}$ by $500 \mathrm{ft}$. Each cell was assumed to have homogeneous and isotropic hydrologic properties that corresponded to the represented hydrogeologic unit. A grid generated using the MODELGRID program with ARC/INFO was used to discretize data for each model layer from data layers that represented land-surface topography and hydrography [USGS 7.5-minute topographic maps for Shellsburg (1968), Fairfax (1968), Cedar Rapids North (1967), and Cedar Rapids South (1967)]; surficial geology (Hallberg and others, 1978); bedrock topography, altitude of the base of the Wapsipinicon Formation, and altitude of the top of the Silurian aquifer (G. Ludvigson, Iowa Department of Natural Resources, Geological Survey Bureau, written commun., 1996); and altitude of the top of the Maquoketa Formation (Parker, 1971).

The three layers of the steady-state model represent the major hydrogeologic units in the model area. Layer 1 represents the Cedar River alluvial aquifer, glacial till aquifer, loess and eolian sand aquifers, and small stream alluvial aquifers (fig. 9). Layer 1 represents the unconfined local ground-water flow systems that discharge to streams. Layer 2 represents the Devonian aquifer, the weathered portion of the local confining unit (Bertram and Otis Formations), and the buried-channel aquifer (fig. 10). Layer 2 is modeled to allow for variable storage and transmissivity due to variable saturated thickness as the layer varies from confined to unconfined. This can occur in areas of the model where large changes in elevation are not adequately represented due to cell size or the approximate thickness of layer 1 . These cells are allowed to go dry during the model simulation. Layer 3 represents the Silurian aquifer and is simulated as a confined layer. The regional confining unit, the Maquoketa Formation, occurs at the base of layer 3 (Silurian aquifer). The base of layer 3 is represented as a no-flow boundary because ground-water flow from the underlying regional confining unit is considered minimal.

The local confining unit, comprised of the Bertram and Otis Formations of the Devonian System, separates layers 2 and 3 in some parts of the model area. The contribution from the unweathered portion of the local confining unit to the horizontal flow of layer 2 or 3 is assumed to be minimal and is simulated by means of a vertical leakance term between the three layers (the Devonian aquifer, the local confining unit, and the Silurian aquifer). This relatively impermeable unit is modeled as a quasi-three-dimensional layer (McDonald and Harbaugh, 1988). Where the confining unit is absent, such as between the buried-channel (layer 2) and Silurian aquifers (layer 3), contribution to 


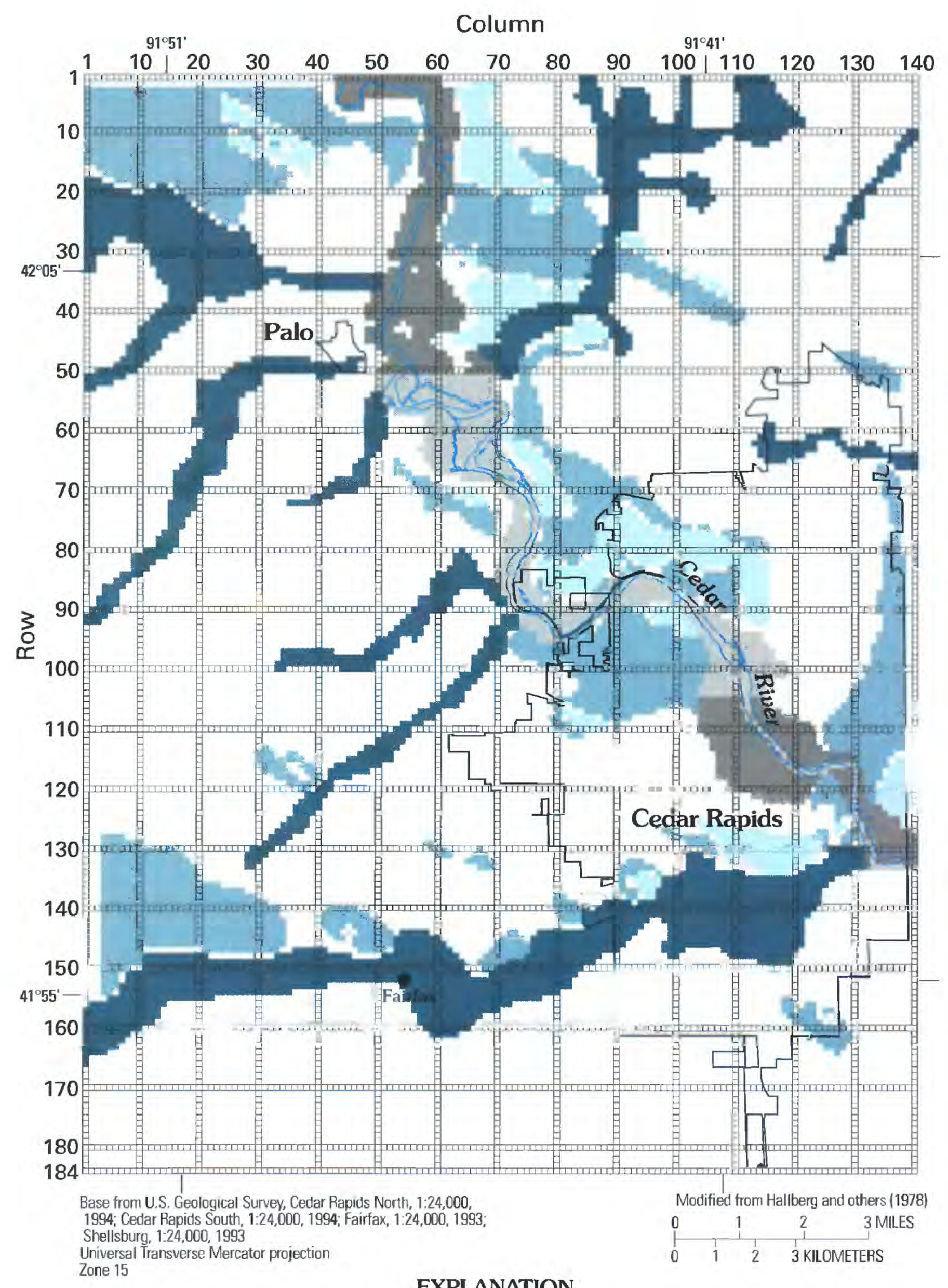

EXPLANATION

Eolian-sand-covered glacial till aquifer

Glacial till aquifer

Loess-covered glacial till aquifer

Cedar River alluvial aquifer
Cedar River alluvial aquifer overlying glacial till

Small stream alluvial aquifer

Model grid-500 feet by 500 feet, showing location of every 10 th row and column

Figure 9. Hydrogeologic units assigned to model layer 1. 


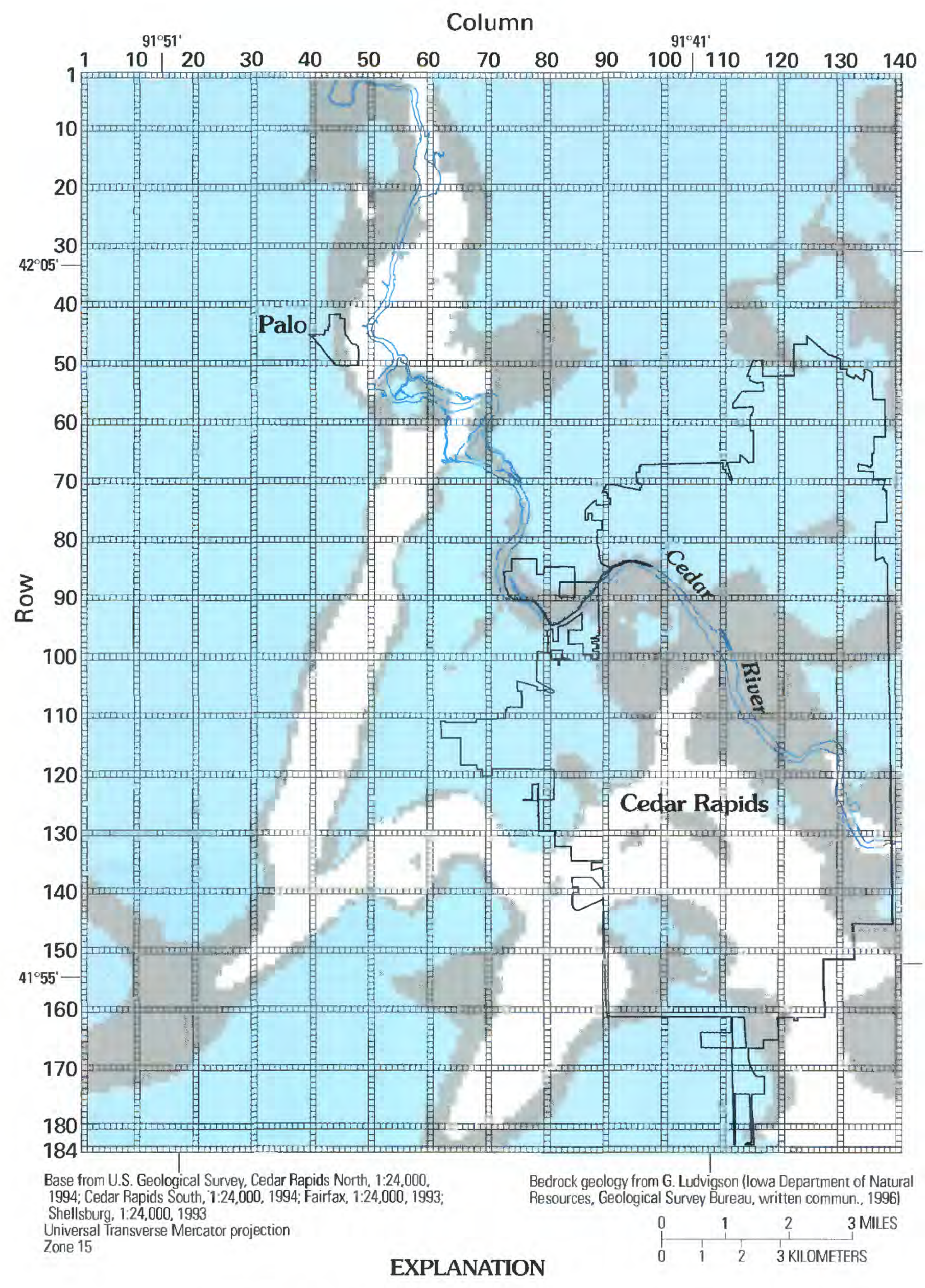

Buried-channel aquifer

Local confining unit (Bertram and Otis Formations)

Devonian aquifer

model grid - 500 feet by 500 feet, showing location of every 10 th row and column

Flgure 10. Hydrogeologic units assigned to model layer 2. 
the horizontal flow of layer 2 or 3 is assumed to be the vertical leakance between layers 2 and 3 .

Boundary conditions for the model were specified to represent conceptualized ground-water flow across the grid boundaries. The top of layer 1 is modeled as a free-surface boundary representing the water table (fig. 11). The perimeter of layer 1 is assumed to be a streamline (no-flow) boundary. A head-dependent boundary forms the southern border and parts of the northern and western borders of layer 2 to simulate flow into or out of the model (fig. 12). A streamline boundary forms the eastern border of layer 2 and was determined from the Devonian and Silurian potentiometric surface (fig. 8). In layer 3, a head-dependent boundary was placed along parts of the northern and western borders and all of the southern border of the model (fig. 13). The eastern border of layer 3 is a streamline boundary as determined from the potentiometric surface (fig. 8). The head-dependent boundaries for layers 2 and 3 simulate flow in the intermediate and regional ground-water flow systems. The distance between the head-dependent boundary and its external source is arbitrarily set at $5 \mathrm{mi}$.

\section{Model Parameters}

Individual cells of the model grid were assigned values for each of the parameters needed by the model to solve the simultaneous ground-water flow equations. The parameters are representative averages specified at the node for each active cell. Spatial variation in the parameters was depicted by assigning values to individual cells in the model. Areally distributed parameters for the model include horizontal and vertical hydraulic conductivity, recharge from precipitation, and discharge to ground-water pumpage. The model code uses transmissivity and fluxes to solve the mathematical equations describing ground-water flow. Transmissivity at each node in the model arrays was calculated by multiplying hydraulic conductivity by the thickness of the layer for a confined unit (most of layer 2) or by the saturated thickness for an unconfined unit (layer 1 and part of layer 2). Transmissivity for layer 3 was calculated outside the model by multiplying hydraulic conductivity by unit thickness and assigning values to nodes.

The complex association of unconsolidated deposits found in the model area required simplification to provide appropriate hydrologic data to the model. The four unconsolidated deposits were divided into six classes of model cells with respect to the subsurface geology for layer 1 (fig. 9). The class determinations were made by compiling surficial geology information (Hallberg and others, 1978), soil information (Schermerhorn and Highland, 1975), test borings and well information, and geophysical information. The six classes for layer 1 are glacial till aquifers, eolian-sandcovered glacial till aquifers, loess-covered glacial till aquifers, Cedar River alluvial aquifer, Cedar River alluvial aquifer overlying glacial till aquifers, and small stream alluvial aquifers. To accurately determine a horizontal and vertical conductivity for each cell of any class, the cell class was apportioned into three subclasses by thickness. The first subclass was 0 to less than $30 \mathrm{ft}$ below land surface, the second subclass was 30 to $60 \mathrm{ft}$ below land surface, and the third subclass was greater than $60 \mathrm{ft}$ below land surface. As the simulated thickness of layer 1 varied, so did the number of subclasses per cell, and in the case of a thickness greater than $60 \mathrm{ft}$, the thickness of the third subclass varied. A horizontal and vertical hydraulic conductivity value was specified for each subclass, which was then weighted by the apportioned thicknesses to determine the average horizontal and vertical conductivity for each model cell. Layer 2 was divided into three cell classes by hydrogeologic units - the Devonian aquifer, the weathered portion of the local confining unit (the Bertram and Otis Formations), and the buried-channel aquifer (fig. 10). Layer 3, representing the Silurian aquifer, was represented as a single-cell class.

The top of layer 1 represents the altitude of the water table, which was set equal to the altitude of the land surface for initial model construction. Land-surface topography data were derived from 1:24,000 USGS digital data for the area covered by Cedar Rapids North, Cedar Rapids South, Shellsburg, and Fairfax USGS 7.5-minute topographic maps. The bottom of layer 1 represents the bedrock surface except where the buried-channel aquifer is represented in layer 2 . The buried-channel aquifer was assumed to be $30 \mathrm{ft}$ thick in the model, and the top of this aquifer formed the base of layer 1. Bedrock topography data were obtained from Greg Ludvigson (Iowa Department of Natural Resources, Geological Survey Bureau, written commun., 1996).

Glacial till is the predominant unconsolidated deposit in model layer 1 (fig. 9). Any unconsolidated deposit in layer 1 not overlain by loess or eolian sand, or not reworked by a stream or the Cedar River, was assumed to be the glacial till aquifer class. The first 


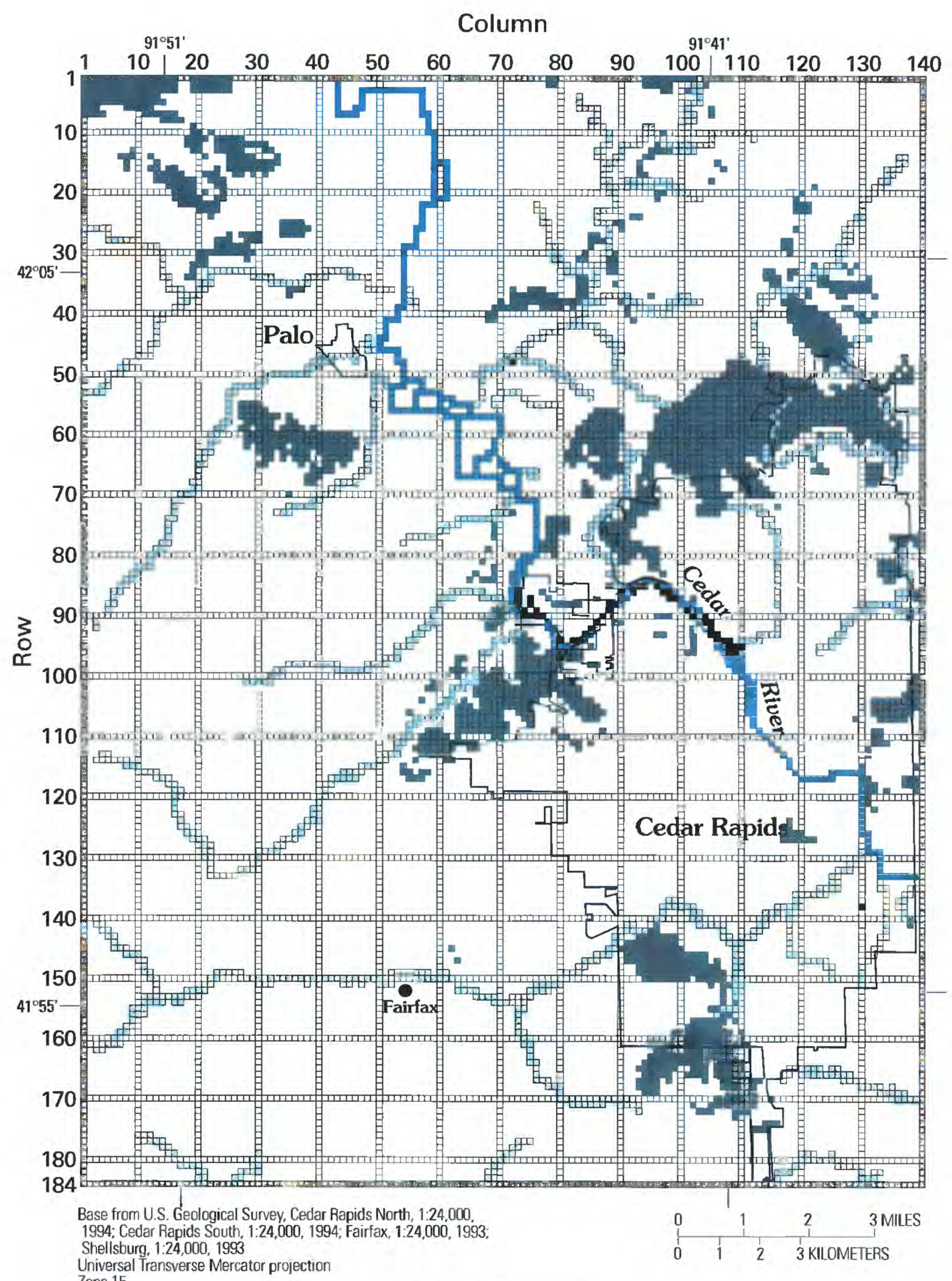

Universal Transverse Mercator projection

\section{EXPLANATION}

\begin{tabular}{|l|l}
$\square$ River cell & Pumping cell \\
Drain cell & Streamline boundary \\
Dry cell & $\begin{array}{l}\text { Model grid- }-500 \text { feet by } 500 \text { feet, } \\
\text { showing location of every } 10 \text { th } \\
\text { row and column }\end{array}$
\end{tabular}

Figure 11. Model grid, river cells, drain cells, dry cells, pumping cells, and boundary of model layer 1. 


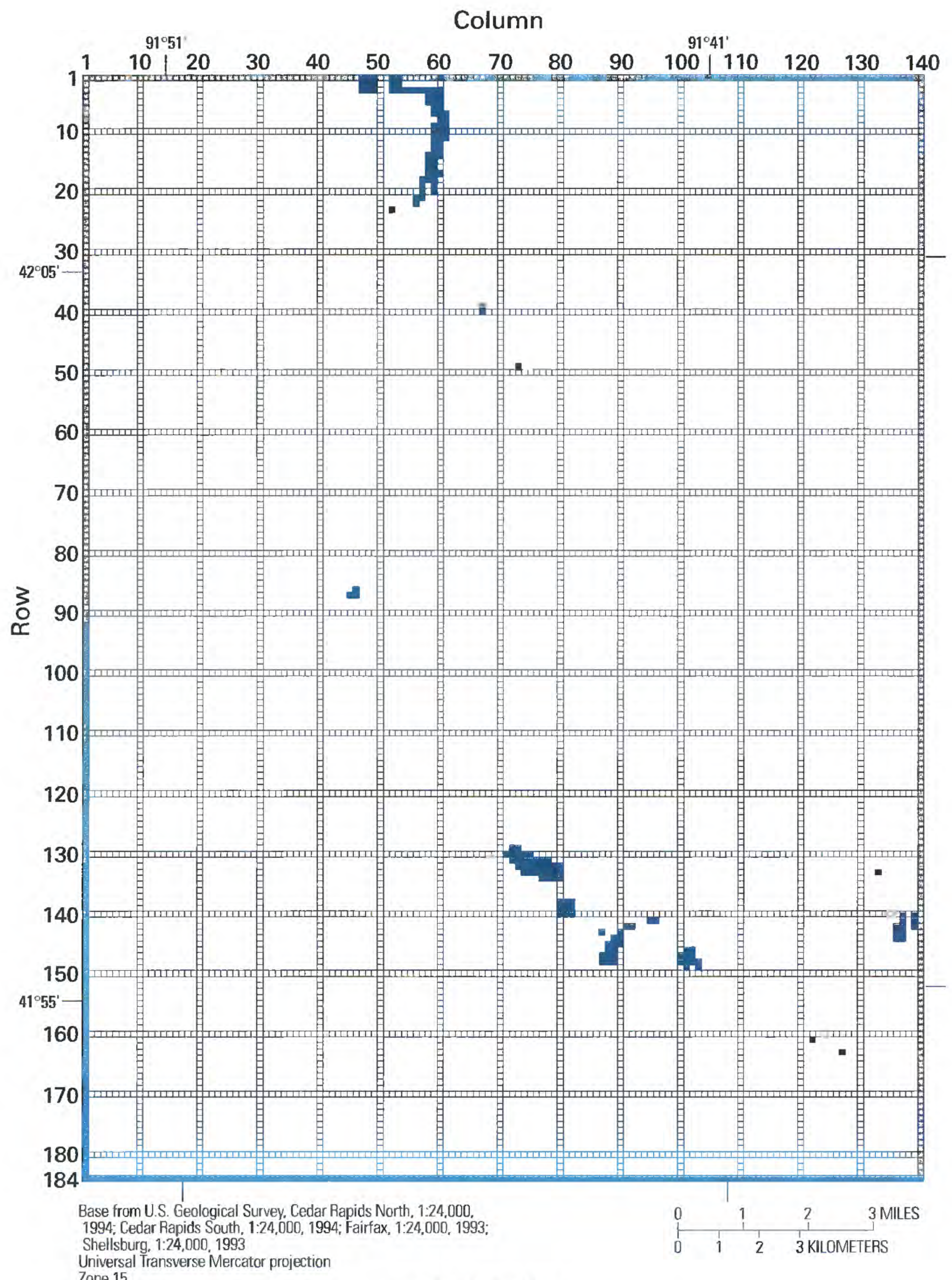

EXPLANATION

Pumping cell for layer 2

No-flow cell

Dry cell
Head-dependent boundary cell

min Model grid-500 feet by 500 feet, showing location of every 10 th row and column

Figure 12. Model grid, boundary conditions, dry cells, and pumping cells for model layer 2. 


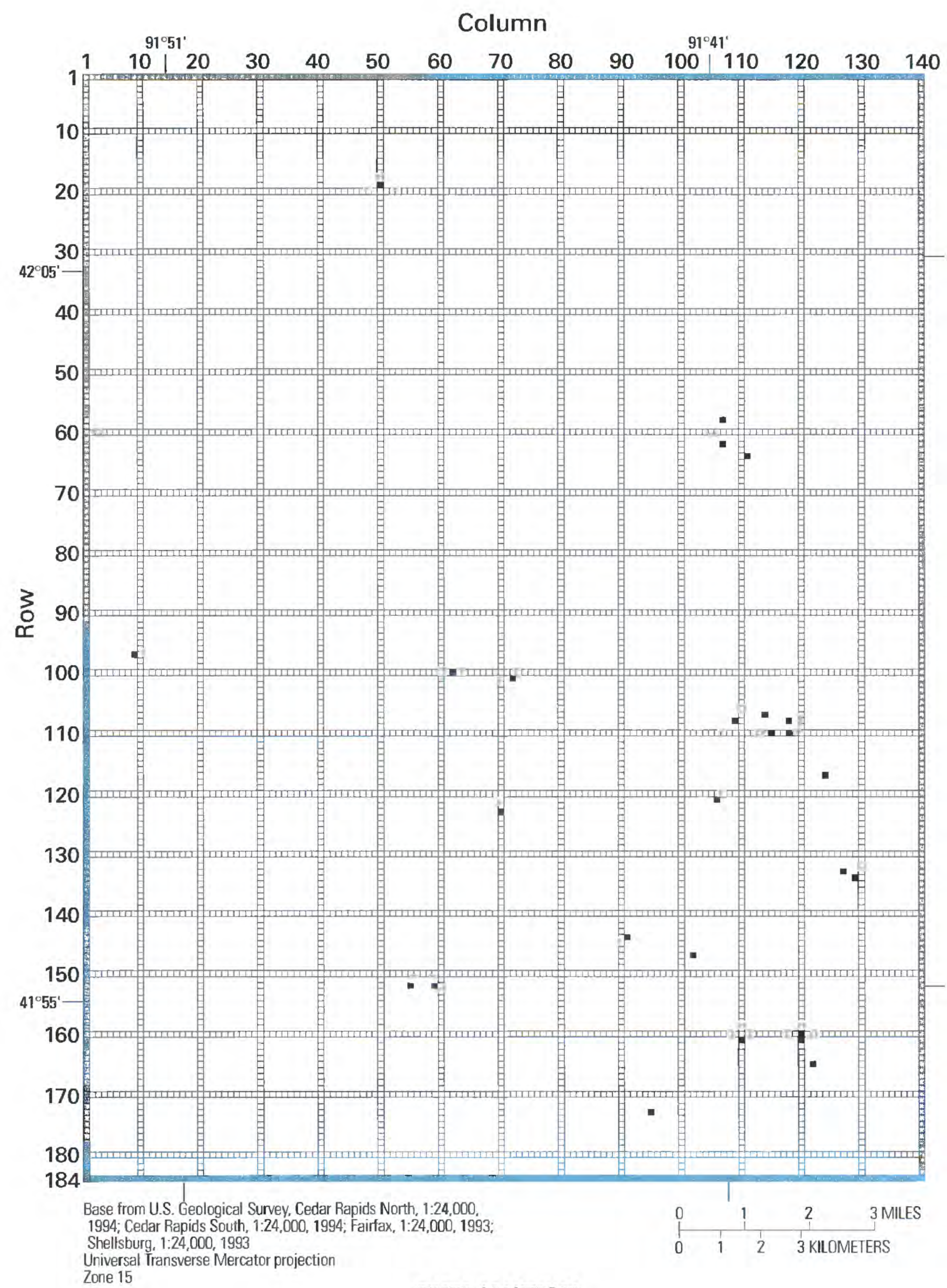

EXPLANATION

$\square$ Pumping cell for layer 3

No-flow cell

Head-dependent boundary cell

Model grid -500 feet by 500 feet, showing location of every 10 th row and column

Flgure 13. Model grid, boundary conditions, and pumping cells for model layer 3. 
subclass was glacial till aquifer overlain by not more than $5 \mathrm{ft}$ of loess and was assumed to be weathered and fractured. The mean hydraulic conductivity of $1 \mathrm{ft} / \mathrm{d}$ used for the first subclass was increased from $8.5 \times 10^{-1} \mathrm{ft} / \mathrm{d}$ for an unweathered glacial till, which could be fractured locally to account for macropores (roots), farming practices, fracturing, and the layer of loess. The second subclass was an unweathered glacial till which could be fractured locally, and a hydraulic conductivity of $8.5 \times 10^{-1} \mathrm{ft} / \mathrm{d}$ was used (W. Simpkins, Iowa State University, written commun., 1994). The third subclass was assumed to be unweathered glacial till, with no apparent fracturing, and a hydraulic conductivity of $4.6 \times 10^{-4} \mathrm{ft} / \mathrm{d}$ was assigned (Hallberg, 1980).

Model areas with loess-covered glacial till and eolian sand-covered glacial till were determined from surficial geology information (Hallberg and others, 1978) and soil information (Schermerhorn and Highland, 1975) (fig. 9). The thickness of the loess and eolian sand deposits is generally $30 \mathrm{ft}$, and these deposits form the first subclass for the loess-covered glacial till aquifer class and the eolian-sand-covered glacial till aquifer class, respectively. Hydraulic conductivity used in the model for the first subclass of the loess-covered glacial till aquifer class was $3.0 \mathrm{ft} / \mathrm{d}$ and for the first subclass of eolian-sand-covered glacial till aquifer was $20.4 \mathrm{ft} / \mathrm{d}$ (table 1). The second and third subclasses of each class were unweathered glacial till aquifer. Hydraulic conductivity for the second and third subclasses of the loess- and eolian-sand-covered glacial till aquifer class were the same as for the second and third subclasses of the glacial till aquifer class.

The Cedar River alluvial aquifer class occurs where the alluvium deposited by the Cedar River is in contact with the Devonian aquifer. The location of this class was determined from drillers' logs and geophysical surveys (fig. 9). The first subclass was a well-sorted, fine-grained sand with an estimated hydraulic conductivity of $150 \mathrm{ft} / \mathrm{d}$. The second subclass was a well-sorted, medium- to coarse-grained sand with an estimated hydraulic conductivity of $200 \mathrm{ft} / \mathrm{d}$. The third subclass was a coarse-grained sand and gravel with some pebbles and cobbles and an estimated hydraulic conductivity of $300 \mathrm{ft} / \mathrm{d}$ (table 1).

The Cedar River alluvial aquifer overlying glacial till aquifer class (fig. 9) is generally located north of Palo and downstream from the low-head dam and I-380 bridge (fig. 2). The first subclass was assumed to be alluvium with an average hydraulic conductivity of
$124 \mathrm{ft} / \mathrm{d}$. The second subclass was unweathered glacial till, which could be fractured locally, and an estimated hydraulic conductivity of $8.5 \times 10^{-1} \mathrm{ft} / \mathrm{d}$ was used in the model. The third subclass was an unweathered glacial till with no apparent fracturing and an estimated hydraulic conductivity of $4.6 \times 10^{-4} \mathrm{ft} / \mathrm{d}$ (table 1 ).

Small stream alluvium aquifers are located along tributary streams to the Cedar River that drain small basins in the model area. The first subclass of the small stream alluvial aquifer class consisted of sand, gravel, silt, and clay with a hydraulic conductivity of $28.1 \mathrm{ft} / \mathrm{d}$ (Kunkle, 1968). The second and third subclasses were unweathered glacial till with hydraulic conductivities of the second and third subclasses of the glacial till aquifer class.

Hydraulic conductivity for each model grid cell of layer 1 was determined by averaging the hydraulic conductivity of the subclasses in that grid cell in relation to their thickness. An average horizontal hydraulic conductivity $\left(\mathrm{K}_{\mathrm{h}} \mathrm{avg}\right)$ and average vertical hydraulic conductivity $\left(\mathrm{K}_{\mathrm{v}}\right.$ avg) were calculated using the following equations (Fetter, 1994, equations 4-40, p. 123, and 4-41, p. 124):

$$
\begin{gathered}
K_{h} a v g=\sum_{m=1}^{n} \frac{K_{h m} b_{m}}{b}, \\
K_{v} a v g=\frac{b}{\sum_{m=1}^{n} \frac{b_{m}}{K_{v m}}},
\end{gathered}
$$

where $K_{h m}$ is horizontal hydraulic conductivity for the mth subclass,

$K_{v m}$ is vertical hydraulic conductivity for $m$ th subclass,

$b_{m}$ is the thickness of the $m$ th subclass, and

$b$ is the total thickness of the class for that cell.

Vertical hydraulic conductivities for glacial till aquifer subclasses, loess-covered glacial till aquifer subclasses, and eolian-sand-covered glacial till aquifer subclasses were estimated using a ratio of 1:100 for vertical hydraulic conductivity to horizontal hydraulic conductivity (Lucey and others, 1995, p. 31). A ratio of $1: 10$ was used to estimate vertical hydraulic conductivity for the Cedar River alluvial aquifer subclasses, the 
Cedar River alluvial aquifer overlying glacial till aquifer subclasses, and the Devonian and Silurian aquifers.

Layer 2 represents the Devonian aquifer, the weathered portion of the local confining unit (Bertram and Otis Formations), and the buried-channel aquifer. Information about the location and thickness of the Devonian aquifer, the weathered portion of the local confining unit (Bertram and Otis Formations), and the buried-channel aquifer was obtained from bedrock topography and equal thickness maps (G. Ludvigson, Iowa Department of Natural Resources, Geological Survey Bureau, written commun., 1996). An average horizontal hydraulic conductivity of $7.0 \mathrm{ft} / \mathrm{d}$ and an estimated vertical hydraulic conductivity of $0.7 \mathrm{ft} / \mathrm{d}$ were used in the model for the Devonian aquifer. The local confining unit was assumed to have been weathered to a depth of $30 \mathrm{ft}$ (Wahl and Bunker, 1986) and to have hydraulic properties similar to the Devonian aquifer. An estimated horizontal hydraulic conductivity of $5.0 \mathrm{ft} / \mathrm{d}$ and an estimated vertical hydraulic conductivity of $0.5 \mathrm{ft} / \mathrm{d}$ were assigned to cells representing the weathered portion of the local confining unit. Where the Devonian aquifer or the weathered portion of the local confining unit was absent, the model cells were assumed to represent part of the buried-channel aquifer. The horizontal hydraulic conductivity used in the model for the buried-channel aquifer was $30.0 \mathrm{ft} / \mathrm{d}$, and the vertical hydraulic conductivity was $3.0 \mathrm{ft} / \mathrm{d}$.

Layer 3 represents the Silurian aquifer. The model grid was superimposed over geographic information system (GIS) data created from maps of equal thickness of the Silurian aquifer (Wahl and Bunker, 1986). The GIS-determined thickness for individual cells and a horizontal hydraulic conductivity of $8.7 \mathrm{ft} / \mathrm{d}$ were used to calculate a transmissivity for layer 3 . A vertical hydraulic conductivity of $0.87 \mathrm{ft} / \mathrm{d}$ was used.

Ground-water flow between adjacent model layers was represented as vertical leakance. The vertical leakance was calculated for two adjacent layers (with common layer contact between) from the thickness between the nodes, the common layer contact, and the vertical hydraulic conductivity for each cell (McDonald and Harbaugh, 1988, equation 51). Vertical leakance was calculated between layers 1 and 2 and between the buried channel of layer 2 and layer 3 . Vertical leakance for two layers with an intervening confining unit was calculated with the above properties and with the vertical hydraulic conductivity and thickness of the confining unit (McDonald and Harbaugh, 1988, equation 52).
Recharge from infiltration of precipitation was accounted for by applying a net recharge rate to the uppermost active cells (the water table). The recharge rate determined by RORA analysis ranged from 6.8 to $7.8 \mathrm{in} / \mathrm{yr}$ for representative small stream basins. A recharge rate of $1.8 \times 10^{-3} \mathrm{ft} / \mathrm{d}(7.9 \mathrm{in} / \mathrm{yr})$ was assigned to cells in layer 1 that represented the Cedar River alluvial aquifer to account for infiltration of runoff from upland areas and larger vertical hydraulic conductivity. A recharge rate of $1.6 \times 10^{-3} \mathrm{ft} / \mathrm{d}(7.0 \mathrm{in} / \mathrm{yr})$ was used for active cells that represented other unconsolidated deposits in layer 1. Application of the recharge to the uppermost active cell was done to account for fluctuation in the water table from layer 1 to layer 2 that might occur due to discretization effects caused by cell size and elevation changes or in areas where layer 1 is thin and the bedrock surface is shallow.

The Cedar River in the model area was simulated by river cells that allow leakage through the river bottom (streambed) into layer 1 on the basis of the difference in water levels and streambed conductance (McDonald and Harbaugh, 1988). Streambed conductance is a function of the width and length of the channel, thickness of streambed material, and vertical hydraulic conductivity of the streambed. The model grid was superimposed over the hydrography data [USGS 7.5-minute topographic maps for Shellsburg (1968), Fairfax (1968), Cedar Rapids North (1967), and Cedar Rapids South (1967)] to select appropriate cells to simulate the river and estimate channel width and length (fig. 11). River stage assigned to river cells was determined by subtracting $3 \mathrm{ft}$ from the altitude of the riverbank. The altitude of the riverbank was determined from the GIS hypsography data layer, and the river stage was estimated to be about $3 \mathrm{ft}$ below the altitude of the riverbank on the basis of visual observation. The altitude of the streambed, based on average depths determined from fathometer soundings, was assumed to be $6 \mathrm{ft}$ below river stage. A streambed thickness of $1 \mathrm{ft}$ and streambed vertical hydraulic conductivity of $1.12 \mathrm{ft} / \mathrm{d}$ were used in the streambed-conductance calculation for the river cells.

Streams in the model area, other than the Cedar River, were simulated as drain cells. The drain cells (fig. 11) removed water from the adjacent aquifer cells on the basis of difference between the head in the aquifer and the altitude of the drain bottom and streambed conductance (McDonald and Harbaugh, 1988). The model grid was superimposed over the hydrography data [USGS 7.5-minute topographic maps for Shells- 
burg (1968), Fairfax (1968), Cedar Rapids North (1967), and Cedar Rapids South (1967)] to select drain cells to represent the streams (fig. 11) and to estimate channel length and width. The streams generally were eroded into the land surface, and the streambed was assumed to be $5 \mathrm{ft}$ below land surface for the drain cells. A streambed vertical hydraulic conductivity of $0.30 \mathrm{ft} / \mathrm{d}$ was assumed for the drain cells.

Sources of discharge from the ground-water flow system in the model area included leakage to the Cedar River and streams (drains), ground-water flow across head-dependent boundaries, and pumping wells. River and drain leakage and flow across the head-dependent boundaries were calculated by the model. Groundwater withdrawals from wells were simulated at pumping cells. Wells in the model area were located on USGS 7.5-minute topographic maps and digitized into GIS data. The model grid was superimposed over GIS data to locate the wells in pumping cells. Well- screen depths were used to assign ground-water withdrawals to the appropriate model layers. The pumping rates assigned to pumping cells were estimated as an average daily volume of the permitted withdrawal registered with the Iowa Department of Natural Resources, an average daily volume determine from pumping information provided by the city of Cedar Rapids, or a fixed volume for private or industrial wells. The model simulated ground-water withdrawals at the pumping cell node, so that multiple private and industrial wells may be represented by a single withdrawal amount at a cell node.

\section{Model Calibration}

Model calibration was performed by comparing water levels measured during December 1994 in 30 wells to model-calculated hydraulic heads (simulated water levels), comparing the direction of ground-water flow, and by comparing calculated base-flow discharge for streams to simulated ground-water discharge to drains. The calibration was accomplished by finding a set of parameters through trial and error that produced simulated hydraulic heads and flows that were similar to measured values. Vertical and horizontal hydraulic conductivity, recharge, and drain and river leakance were adjusted within reasonable limits, and the output evaluated for each model execution to ascertain any improvement in the calibration to minimize the difference between the measured and simulated values.
The number and location of dry cells per layer was monitored to find a solution with the least number of dry cells that fits the hydrogeologic conceptualization. Dry cells in layer 1 occurred in areas of steep topography or on topographic highs where a thin layer of unconsolidated material overlies shallow bedrock. In this situation, layer 2 converted to unconfined conditions, the position of the water table was simulated within the bedrock (fig. 11), and the net recharge rate was applied to the water table in layer 2. Dry cells also occurred in layer 2 with overlying saturated cells in layer 1 in areas of complex geology or topography. The dry cells in the vicinity of row 87 , column 46 , and row 132, column 75 (fig. 12), were located on the edge of the buried channel (fig. 10) where the bedrock topography was steep. Dry cells could be a result of discretization error due to cell size and elevation changes in the bedrock surface. Other dry cells in layer 2 could have been affected by wells in layer 3 (in the vicinity of row 144, column 90, and row 147, column 102; figs. 12 and 13).

During calibration, the root mean square error (RMSE) and average-head difference (AVEH) of measured and simulated ground-water levels were evaluated for each model execution to determine improvements in model results. RMSE is a measure of the magnitude of error between measured and simulated ground-water levels over the entire model area (Tucci, 1992, p. 54). AVEH is a measure of the systematic error; it approaches zero when the sum of the differences between measured and simulated groundwater levels that are greater than zero equals the sum of the differences that are less than zero (Lucey and others, 1995). Water levels from 30 wells (fig. 14) were used for comparison with calculated values from the model-20 wells in layer 1, 4 wells in layer 2, and 6 wells in layer 3. The RMSE and the AVEH for all three layers of the model simulation were 4.5 and $0.01 \mathrm{ft}$, respectively. The individual calibrated values for RMSE and AVEH were 4.5 and $0.4 \mathrm{ft}$ in layer 1, 5.3 and $1.4 \mathrm{ft}$ in layer 2, and 3.9 and $-2.2 \mathrm{ft}$ in layer 3 , respectively. Many of the wells used to represent the potentiometric surface of the Devonian and Silurian aquifers in the model area were not used to calculate the RMSE and AVEH due to active pumpage prior to or during measurement (Schnoebelen and Schulmeyer, 1996).

Calculated base-flow discharge per square mile of drainage basin for streams in similar hydrologic settings was compared to simulated ground-water dis- 


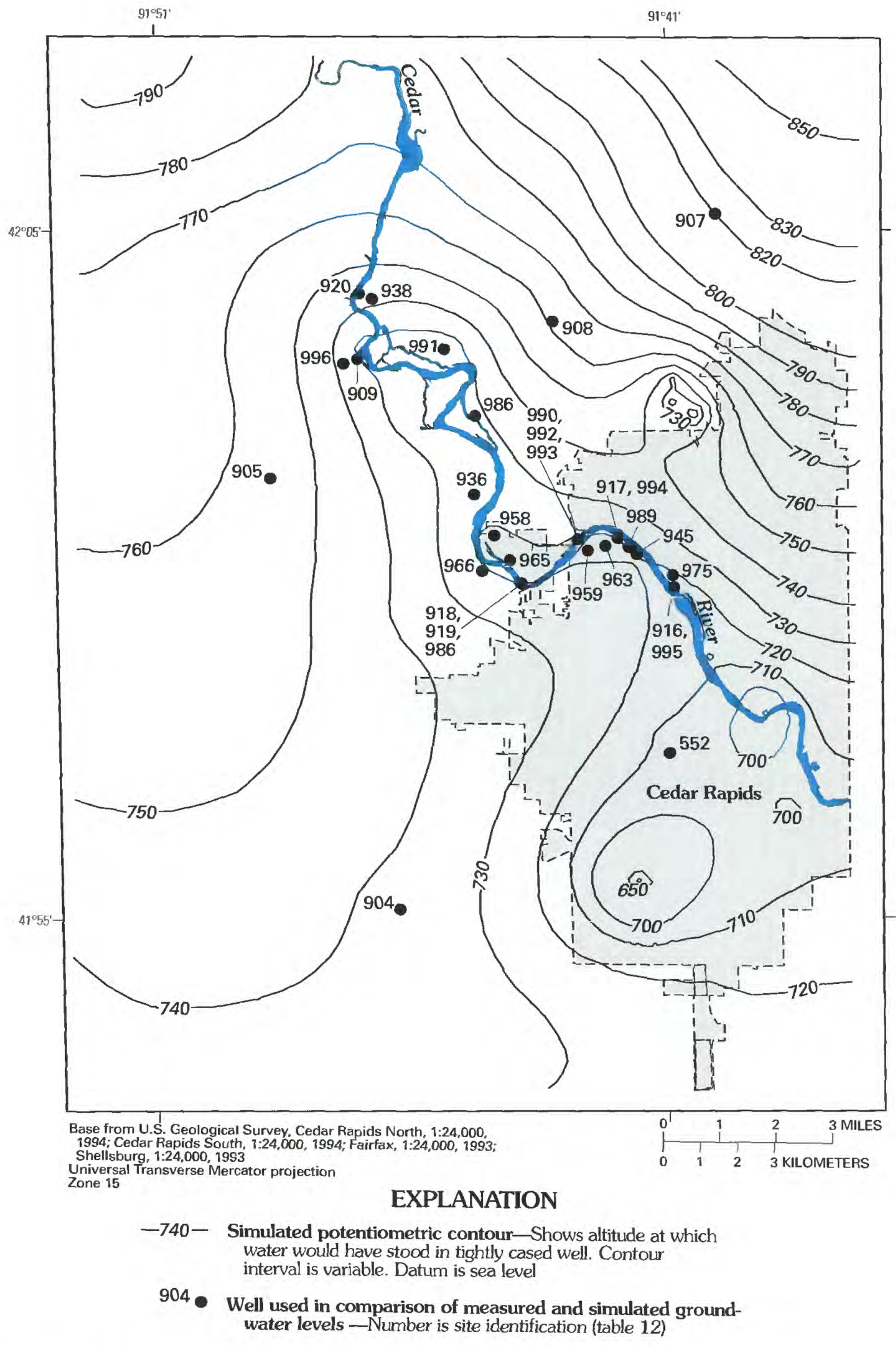

Figure 14. Simulated potentiometric surface for model layer 3. 
charge to drains in nine subbasins (fig. 15) during the calibration process. The calculated base-flow discharge per square mile of drainage basin for streams of similar hydrologic setting ranged from 0.38 to $0.47\left(\mathrm{ft}^{3} / \mathrm{s}\right) / \mathrm{mi}^{2}$ (table 2), and simulated ground-water discharge for selected subbasins ranged from 0.16 to $0.57\left(\mathrm{ft}^{3} / \mathrm{s}\right) / \mathrm{mi}^{2}$ (table 4 and fig. 15). The calculated base-flow discharge in Prairie Creek at Fairfax measured $0.43\left(\mathrm{ft}^{3} / \mathrm{s}\right) / \mathrm{mi}^{2}$, and the simulated ground-water discharge was $0.38\left(\mathrm{ft}^{3} \mathrm{~s}\right) / \mathrm{mi}^{2}$ to Prairie Creek subbasin. The mean calculated base-flow discharge of $0.44\left(\mathrm{ft}^{3} \mathrm{~s}\right) / \mathrm{mi}^{2}$ for all streams (table 2) is greater than the simulated ground-water discharge for Lone Tree Creek (subbasin 9), Dry Creek (east) (subbasin 3), and Cedar River (subbasin 6), 0.28, 0.16, and $0.18\left(\mathrm{ft}^{3} / \mathrm{s}\right) / \mathrm{mi}^{2}$, respectively. Lone Tree Creek is depicted as an intermittent stream on USGS 7.5-minute topographic maps. Its streambed may be above the water table during a portion of the year and could have a base-flow discharge smaller than the average. The small simulated ground-water discharge for Dry Creek (east) could be a result of discretization error due to cell size and elevation change. The streambed may be incised deeper into the landscape than is simulated in the model, which would steepen the hydraulic gradient and allow more ground-water discharge to the creek. Although this could be of concern to the local drainage area of the subbasin, it is not critical to the main focus of this study to assess ground-water flow on a large scale and to determine sources of water to the Cedar River alluvial aquifer. The ground-water discharge to the Cedar River in subbasin 6 is small because the subbasin area is only a small part of the total Cedar River Basin area and pumping from the Cedar River alluvial aquifer decreases the amount of ground-water discharge. Simulated ground-water discharge for other selected subbasins is similar to calculated base-flow discharge in streams of similar hydrologic setting.

The simulated ground-water discharge to the Cedar River was calculated using results from several subbasins that discharge into the Cedar River in the model area. The subbasins that contribute simulated ground-water discharge to the Cedar River are 2, 4, 6, $7,9,10,11$, and 12 (fig. 15). Subbasin 3 was not used because it discharges to the Cedar River at a point outside the modeled area. The sum of simulated ground-water discharge for these subbasins divided by the sum of their drainage areas equals $0.35\left(\mathrm{ft}^{3} / \mathrm{s}\right) / \mathrm{mi}^{2}$ (table 4). The calculated base-flow discharge for the Cedar River was $0.35\left(\mathrm{ft}^{3} / \mathrm{s}\right) / \mathrm{mi}^{2}$ (table 2).
Another step in the calibration process evaluated the accuracy of simulated ground-water flow direction. The simulated potentiometric surface for model layer 3, representing the Silurian aquifer (fig. 14), was compared to the potentiometric surface of the Devonian and Silurian aquifers constructed from water levels measured June through August 1993 (fig. 8). Both simulated and measured potentiometric surfaces indicated ground-water flow towards the Cedar River between Palo and Cedar Rapids.

Calibration of the steady-state model was assumed adequate when the following criteria were met:

1. Incremental changes in model input parameters did not produce an AVEH closer to zero or a smaller RMSE for all layers in the model;

2. The RMSE of $4.5 \mathrm{ft}$ and AVEH of $0.01 \mathrm{ft}$ for all layers represent a small percentage of the range in measured ground-water levels;

3. The average simulated ground-water discharge to selected subbasins (table 4) was $0.35\left(\mathrm{ft}^{3} / \mathrm{s}\right) / \mathrm{mi}^{2}$ similar to the average calculated base-flow discharge of selected streams $\left[0.44\left(\mathrm{ft}^{3} / \mathrm{s}\right) / \mathrm{mi}^{2}\right]$ (table 2). Ground-water discharge to the Cedar River in the model (table 4) equaled the calculated base-flow discharge of selected streams to the Cedar River $\left[0.35\left(\mathrm{ft}^{3} / \mathrm{s}\right) / \mathrm{mi}^{2}\right]$ (table 2).

4. Simulated lateral ground-water flow directions compare favorably to the interpreted flow directions from the potentiometric-surface map on the basis of water levels measured during June through August 1993 for the Devonian and Silurian aquifers.

\section{Sensitivity Analysis}

A sensitivity analysis quantifies the effects of presumed uncertainty in values of model input parameters on the simulated water levels and flows. This uncertainty is a result of selecting input parameters with limited measured data and geologic knowledge of the system geometry that are used in mathematical equations to simulate the hydrologic system. The sensitivity analysis involves systematically changing one parameter at a time, with other parameters remaining unchanged, and analyzing the effect on model output. Hydraulic conductivity, recharge, and boundary conditions were varied to establish which parameters have the greatest effect on the results, such as water level and ground-water discharge. Improvements in the 


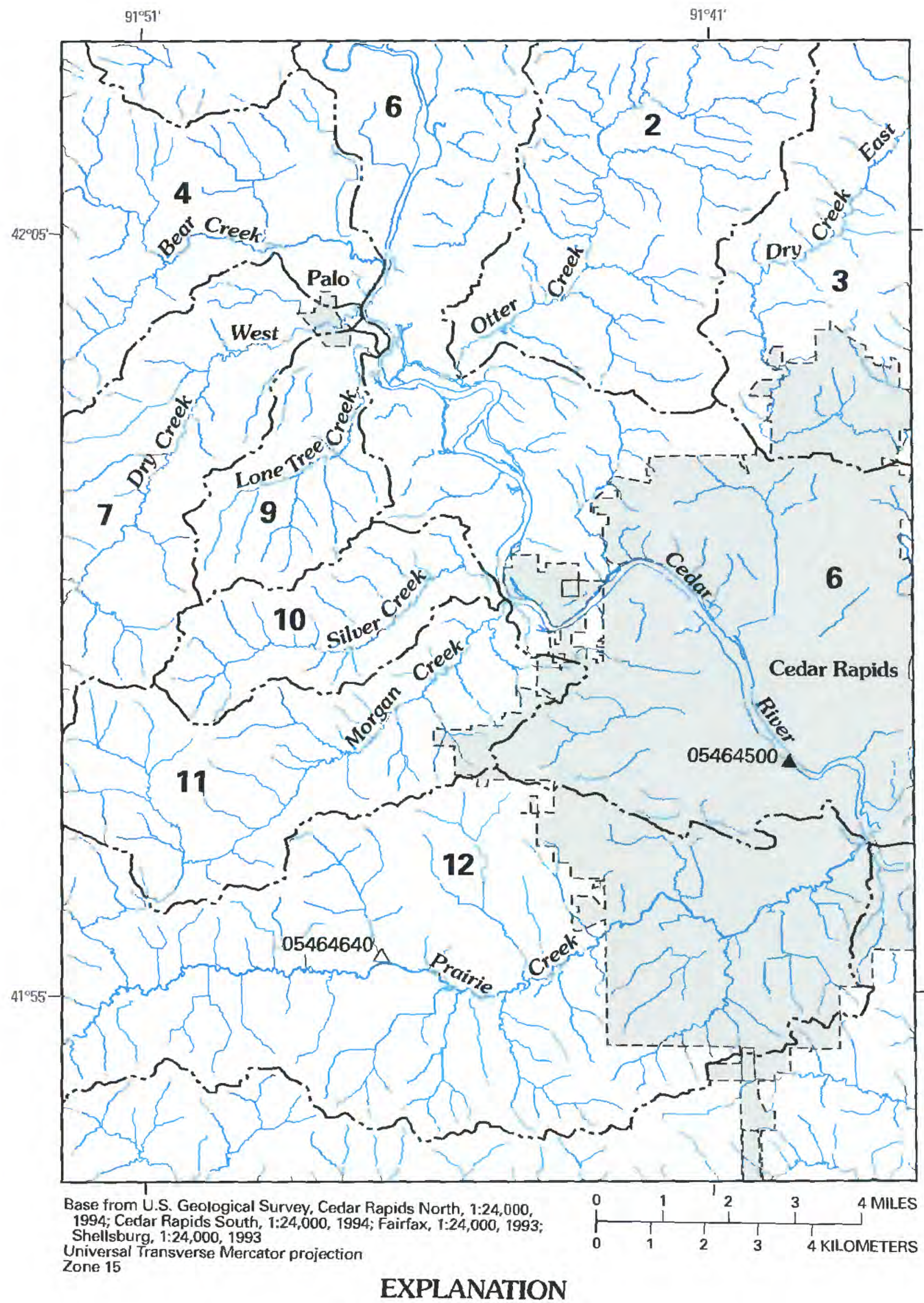

\section{EXPLANATION}

Subbasin boundary

12 Subbasin number (table 5)

05464500 A Continuous-record gaging station and number $05464640 \triangle$

Discontinued continuous-record gaging station and number

Figure 15. Location of subbasins in model area.

model might result from more accurately determining the value of the most sensitive parameters.
The response of simulated water levels to changes in selected input parameters is shown in figure 16. The 
Table 4. Simulated ground-water discharge to selected subbasins in model area and to the Cedar River [mi ${ }^{2}$, square mile; $\mathrm{ft}^{3} / \mathrm{d}$, cubic feet per day; $\left(\mathrm{ft}^{3} / \mathrm{s}\right) / \mathrm{mi}^{2}$, cubic feet per second per square mile]

\begin{tabular}{|c|c|c|c|c|}
\hline $\begin{array}{l}\text { Stream name } \\
\text { (fig. 15) }\end{array}$ & $\begin{array}{l}\text { Subbasin } \\
\text { number } \\
\text { (fig. 15) }\end{array}$ & $\begin{array}{c}\text { Drainage area } \\
\text { in model } \\
\left(\mathrm{mi}^{2}\right)\end{array}$ & $\begin{array}{l}\text { Simulated } \\
\text { ground-water } \\
\text { discharge to } \\
\text { drains } \\
\left(\mathrm{ft}^{3} / \mathrm{d}\right)\end{array}$ & $\begin{array}{c}\text { Simulated } \\
\text { ground-water } \\
\text { discharge per } \\
\text { area } \\
{\left[\left(\mathrm{ft}^{3} / \mathrm{s}\right) / \mathrm{mi}^{2}\right]}\end{array}$ \\
\hline Otter Creek & 2 & 20.11 & 885,030 & 0.51 \\
\hline Dry Creek (east) & 3 & 14.87 & 200,720 & .16 \\
\hline Bear Creek & 4 & 14.98 & 731,920 & .57 \\
\hline Cedar River & 6 & 53.3 & 828,220 & .18 \\
\hline Dry Creek (west) & 7 & 14.06 & 476,400 & .39 \\
\hline Lone Tree Creek & 9 & 7.29 & 173,840 & .28 \\
\hline Silver Creek & 10 & 8.06 & 276,190 & .40 \\
\hline Morgan Creek & 11 & 17.76 & 578,360 & .38 \\
\hline Prairie Creek & 12 & 48.38 & $1,575,200$ & .38 \\
\hline $\begin{array}{l}\text { Simulated ground-water dis- } \\
\text { charge to the Cedar River } \\
\text { from selected subbasins }\end{array}$ & $\begin{array}{l}2,4,6,7,9,10 \\
\quad 11,12\end{array}$ & 183.94 & $5,525,160$ & .35 \\
\hline
\end{tabular}

RMSE is plotted against the multiplication factor used to vary the input parameter. Values from the calibrated model are used for comparison and are represented by the multiplication factor of 1 . The multiplication factor is applied uniformly to the entire model for the indicated parameter and ranged from 0.1 to 10 . The magnitude of the resultant change in heads from calibrated values is a measure of the model's sensitivity to change in a particular parameter (Anderson and Woessner, 1992). Simulated water levels were most sensitive to changes in recharge, decreases in hydraulic conductivity in layer 1 , and to transmissivity for layer 3

(fig. 16). The model also showed sensitivity to changes in vertical leakance between layers 1 and 2 and in horizontal hydraulic conductivity for layer 2 for values greater than 1 (fig. 16). Decreases in the multiplication factor for some parameters seemed to improve the RMSE value although the AVEH increased. These values when compared to reported values in table 1 are unrealistic. The model did not come to a solution with a multiplication factor of 0.1 for the parameters recharge and transmissivity, and 0.25 was the smallest multiplication factor used.

The sensitivity of simulated river leakage to changes in model input parameters also was examined by determining the proportion of simulated inflow to the ground-water flow system obtained from river leak- age and the proportion of simulated outflow from the flow system due to ground-water discharge to the river (fig. 17). The proportion of simulated inflow obtained from river leakage was most sensitive to changes in recharge. The proportion of simulated outflow due to ground-water discharge to the river was most sensitive to changes in horizontal hydraulic conductivity in layer 1 , transmissivity in layer 3 , and to changes in drain conductance.

Sensitivity of head-dependent boundaries were evaluated by comparing results of a model simulation with pumping to those of a model simulation without pumping. Inflow across the head-dependent boundaries increased less than 1 percent with pumping, which indicates the insensitive nature of model results to this boundary.

\section{Model Limitations}

The model calibration and sensitivity analysis indicate a viable solution for the model, although the solution is not unique and has limited applicability. This ground-water flow model was developed to simulate ground-water flow and to quantify the sources of water to the Cedar River alluvial aquifer under presumed steady-state conditions. The size of the model cells and the limited geologic and hydrologic knowledge of the 


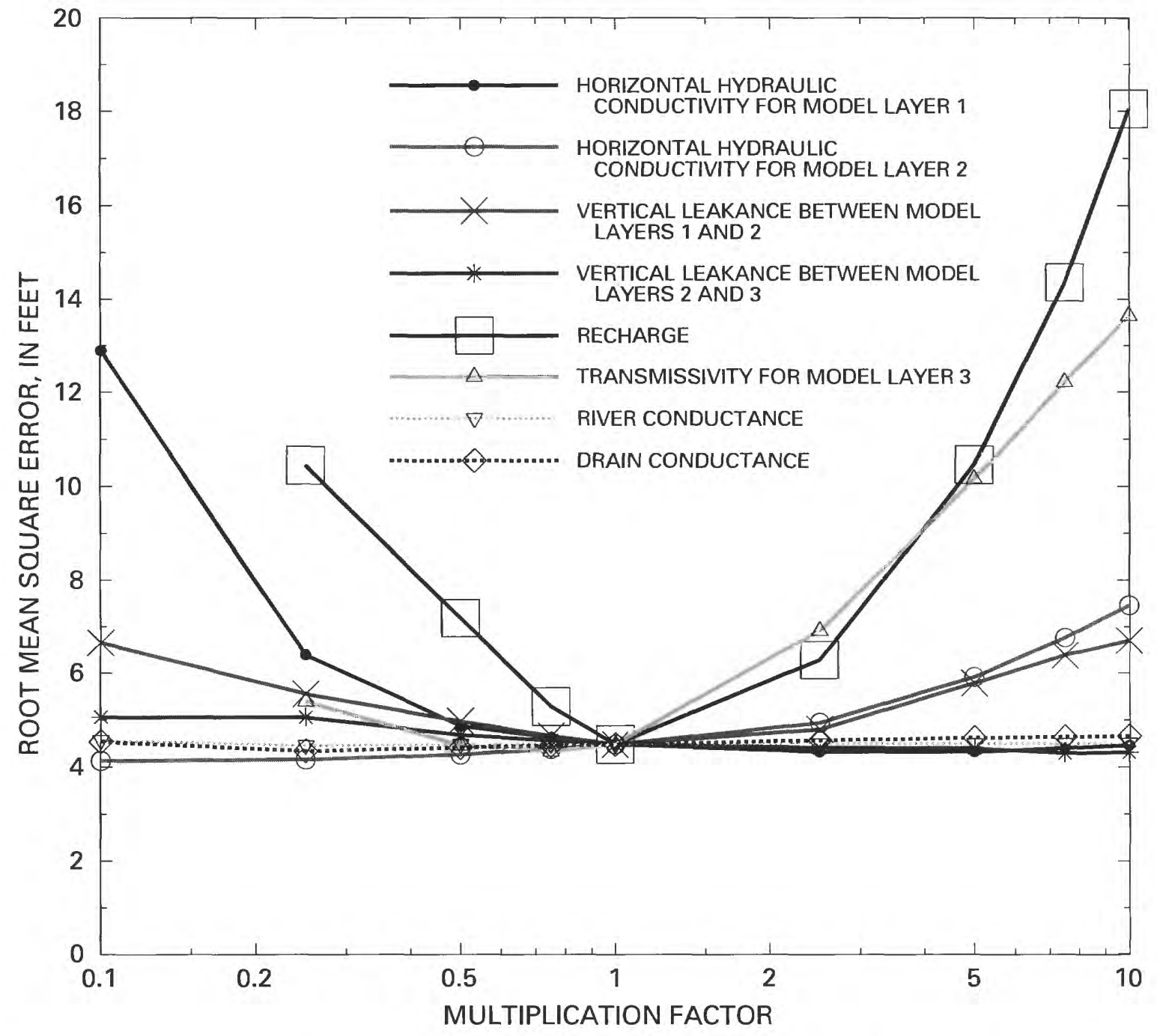

Figure 16. Root mean square error between measured $(A)$ and $(B)$ simulated water levels as a result of varying model input parameters by a multiplication factor.

system introduced inaccuracies because of the heterogeneous nature of geologic materials and variability of climatic conditions. The model provides information to evaluate ground-water flow on a regional scale and cannot accurately simulate drawdown near individual pumping wells or be used to accurately simulate capture zones for individual wells. A model with a finer grid would be required for such detailed analysis. The steady-state model assumed that inflow to the ground-water system equaled outflow. If this was not the case during December 1994, the change in ground-water storage would be a source of model error. The model did not accurately represent the effect that rising and falling water levels in the Cedar River would have on the Cedar River alluvial aquifer.

The model can be used to evaluate changes in hydraulic head (ground-water levels) and ground- water flow that could result from hydrologic stresses, such as less-than-average annual precipitation or increased pumpage, for a presumed steady-state condition. For example, simulated results from pumping scenarios can indicate changes in the amount or percentage of contribution from sources of water in relation to the presumed steady-state conditions in December 1994 and in the potentiometric surface.

\section{Results of Steady-State Simulation}

In the steady-state ground-water flow model, the numerical solution to the differential form of Darcy's law calculates a mass balance such that a mass of water is conserved at every point in the system. Results of the solution are provided as a quantitative balance of 

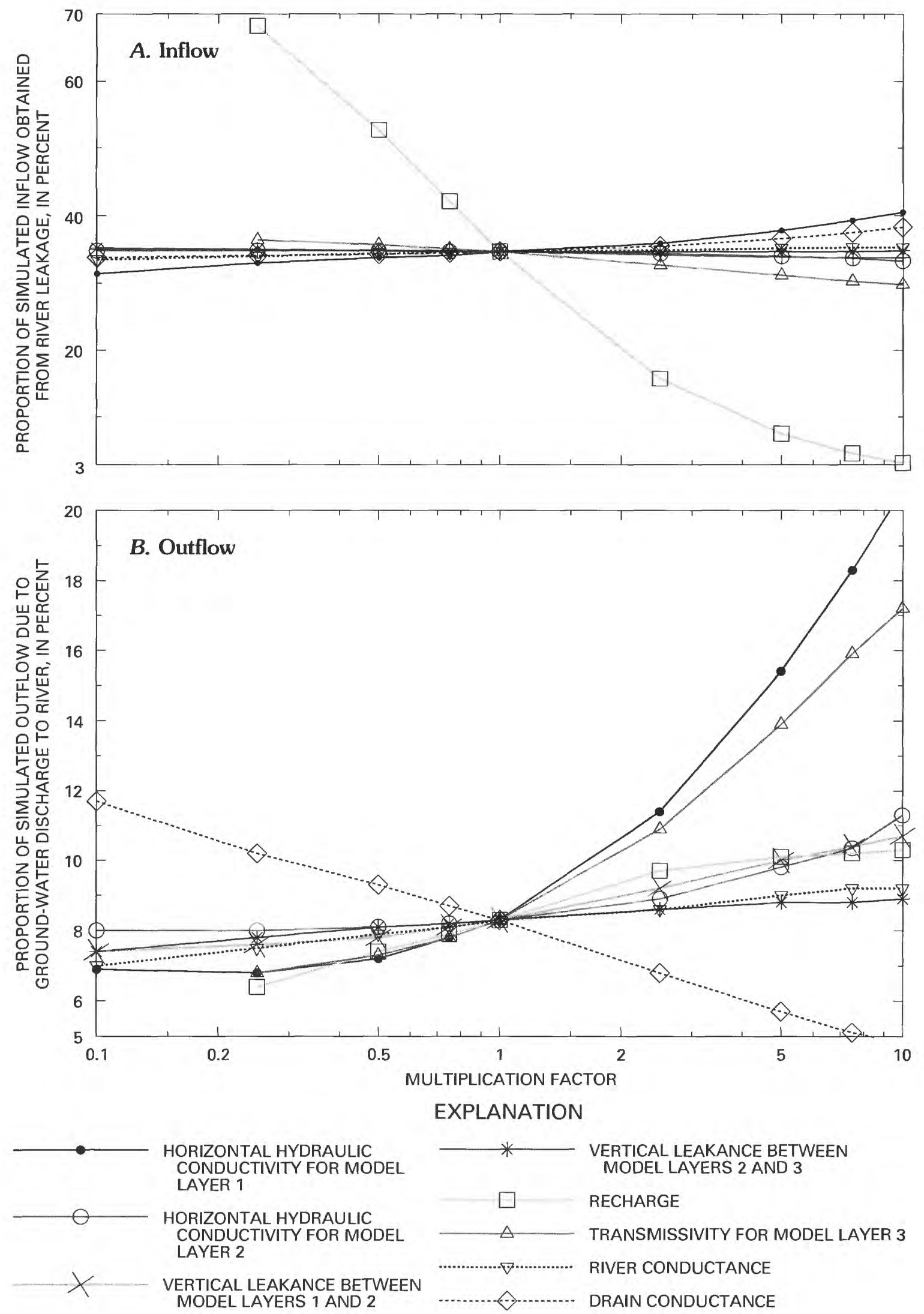

Figure 17. Proportion of simulated $(A)$ inflow and $(B)$ outflow obtained from river leakage as a result of varying model input parameters by a multiplication factor. 
inflow and outflow for the model, as calculated ground-water levels, drawdown values for the water table or potentiometric surface, and as cell-by-cell flow data. These results can then be used by post-processing programs, such as ZONEBUDGET and MODPATH, for further analysis of the model results.

Primary sources of inflow to the model are precipitation (63.5 percent), river leakage ( 34.7 percent), and flow across the head-dependent boundaries (1.8 percent) (table 5). Infiltration of precipitation occurs primarily through the unconsolidated material, whereas river leakage is an important source of recharge to the Cedar River alluvial aquifer in areas where pumping occurs. Primary sources of outflow from the model are pumpage (48.3 percent), drain leakage (42.2 percent), and river leakage ( 8.3 percent).

The effects of pumping on the aquifers can be shown by comparing results of the model simulation with no pumping (fig. 18) to those of the model simulation with pumping (fig. 19). With no pumping (fig. 18), the drains and the river are the major discharge areas for the system. The sum of the simulated ground-water discharge to the drains and river $\left(9,867,182 \mathrm{ft}^{3} / \mathrm{d}\right)$ approximates the amount of recharge to layer 1 as infiltration of precipitation $\left(9,232,100 \mathrm{ft}^{3} / \mathrm{d}\right)$. A small amount $\left(165,830 \mathrm{ft}^{3} / \mathrm{d}\right)$ of river leakage enters the Cedar River alluvial aquifer, the hydrogeologic unit in layer 1 adjacent to the Cedar River. With pumping (fig. 19), the amount of discharge to drains and the river decreases to $7,766,718 \mathrm{ft}^{3} / \mathrm{d}$, whereas the amount of river leakage to layer 1 (the Cedar River alluvial aquifer) increases to $5,329,300 \mathrm{ft}^{3} / \mathrm{d}$. With pumping, the river becomes a losing river, most likely in the vicinity of the municipal well fields. By comparing the results of the two model simulations, about 97 percent of the inflow to layer 1 is from river leakage caused by pumping for the steadystate simulation.

Sources of inflow to and outflow from the Cedar River alluvial aquifer with pumping were determined by conducting a quantitative budget analysis, including leakage from adjacent hydrogeologic units (fig. 9) as budget components (table 6). The primary sources of inflow to the Cedar River alluvial aquifer are from river leakage (74.2 percent) and vertical leakage from layer 2 (14.8 percent). Infiltration of precipitation accounts for 4.9 percent of total inflow. Pumpage from the Cedar River alluvial aquifer accounts for 78.0 percent of outflow. River leakage accounts for 13.7 percent of outflow and occurs in areas distant from the municipal well fields.

Particle-tracking analysis of the simulated ground-water flow system with the post-processing MODPATH program was used to indicate the approximate extent of areas that contribute water to the municipal well fields in the Cedar River alluvial aquifer. Assumed porosity values used in the model were: Cedar River alluvium, 0.39; stream alluvium, 0.34; loess, 0.49; eolian sand, 0.43; glacial till, 0.31; Cedar River alluvium overlying glacial till, 0.34 ; Devonian aquifer, 0.26 ; weathered local confining unit, 0.16 ; buried channel, 0.39; confining layer, 0.06; and the Silurian aquifer, 0.26 . Hypothetical particles were placed at the center of pumping cells that represent municipal wells and a backward-tracking analysis was used to estimate the approximate areas of contribution for the municipal well fields for 1-, 5-, and 10-year periods (fig. 20). Results indicate that the primary source of water for the well fields is the Cedar River alluvial aquifer.

Table 5. Model-calculated water budget for steady-state conditions

[Inflow, water being added to the ground-water system; $\mathrm{ft}^{3} / \mathrm{d}$, cubic feet per day; outflow, water being removed from the ground-water system]

\begin{tabular}{lrccc}
\hline \multicolumn{1}{c}{ Water-budget component } & $\begin{array}{r}\text { Inflow } \\
\left(\mathbf{f t}^{\mathbf{3}} / \mathbf{d}\right)\end{array}$ & $\begin{array}{c}\text { Percentage of } \\
\text { total inflow }\end{array}$ & $\begin{array}{c}\text { Outflow } \\
\left(\mathbf{f t}^{\mathbf{3}} / \mathbf{d}\right)\end{array}$ & $\begin{array}{c}\text { Percentage of } \\
\text { total outflow }\end{array}$ \\
\hline Infiltration of precipitation & $9,763,650$ & 63.5 & 0 & 0 \\
River leakage & $5,329,251$ & 34.7 & $1,275,120$ & 8.3 \\
Drain leakage & 0 & 0 & $6,491,633$ & 42.2 \\
Pumpage & 0 & 0 & $7,432,900$ & 48.3 \\
Head-dependent boundaries & 283,755 & 1.8 & 176,306 & 1.2 \\
Total & $\mathbf{1 5 , 3 7 6 , 6 5 6}$ & $\mathbf{1 0 0 . 0}$ & $\mathbf{1 5 , 3 7 5 , 9 5 9}$ & $\mathbf{1 0 0 . 0}$ \\
\hline
\end{tabular}




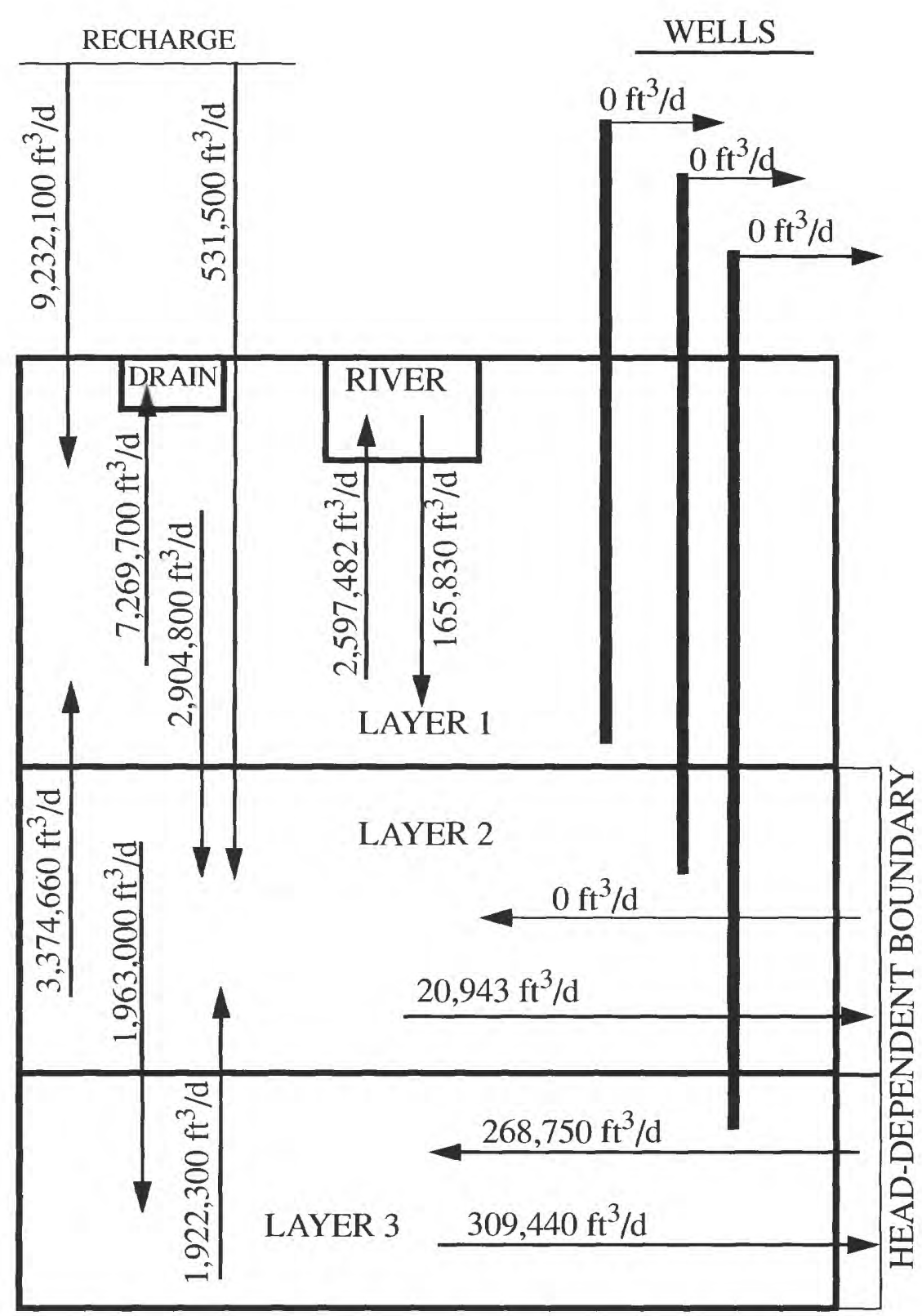

Figure 18. Model-calculated water-budget components for three layers of ground-water flow model with no wells pumping. All values are in cubic feet per day $\left(\mathrm{tt}^{3} / \mathrm{d}\right)$.

\section{Simulation of Hypothetical Conditions}

For two scenarios, simulations of hypothetical conditions using the steady-state ground-water flow model were conducted to evaluate quantitative changes on sources of water to the Cedar River alluvial aquifer compared to December 1994 hydrologic conditions in the calibrated model. The first scenario simulated a period of less-than-average annual precipitation for 1961-90. The second scenario simulated increased pumping from the municipal well fields.
The average annual precipitation for $1961-90$ in east-central Iowa was about $36.4 \mathrm{in} / \mathrm{yr}$ (Owenby and Ezel1, 1992), and mean annual flow of the Cedar River at Cedar Rapids, based on streamflow data for October 1903 through September 1994, was about 3,670 $\mathrm{ft}^{3} / \mathrm{s}$ (May and others, 1994). The Cedar Rapids area received 24.6 in. of precipitation during 1989 , and the mean annual flow in the Cedar River was $997 \mathrm{ft}^{3} / \mathrm{s}$ from October 1988 through September 1989 (O'Connell and others, 1989). Mean monthly flows in the Cedar River from June through September 1989 were less than the 


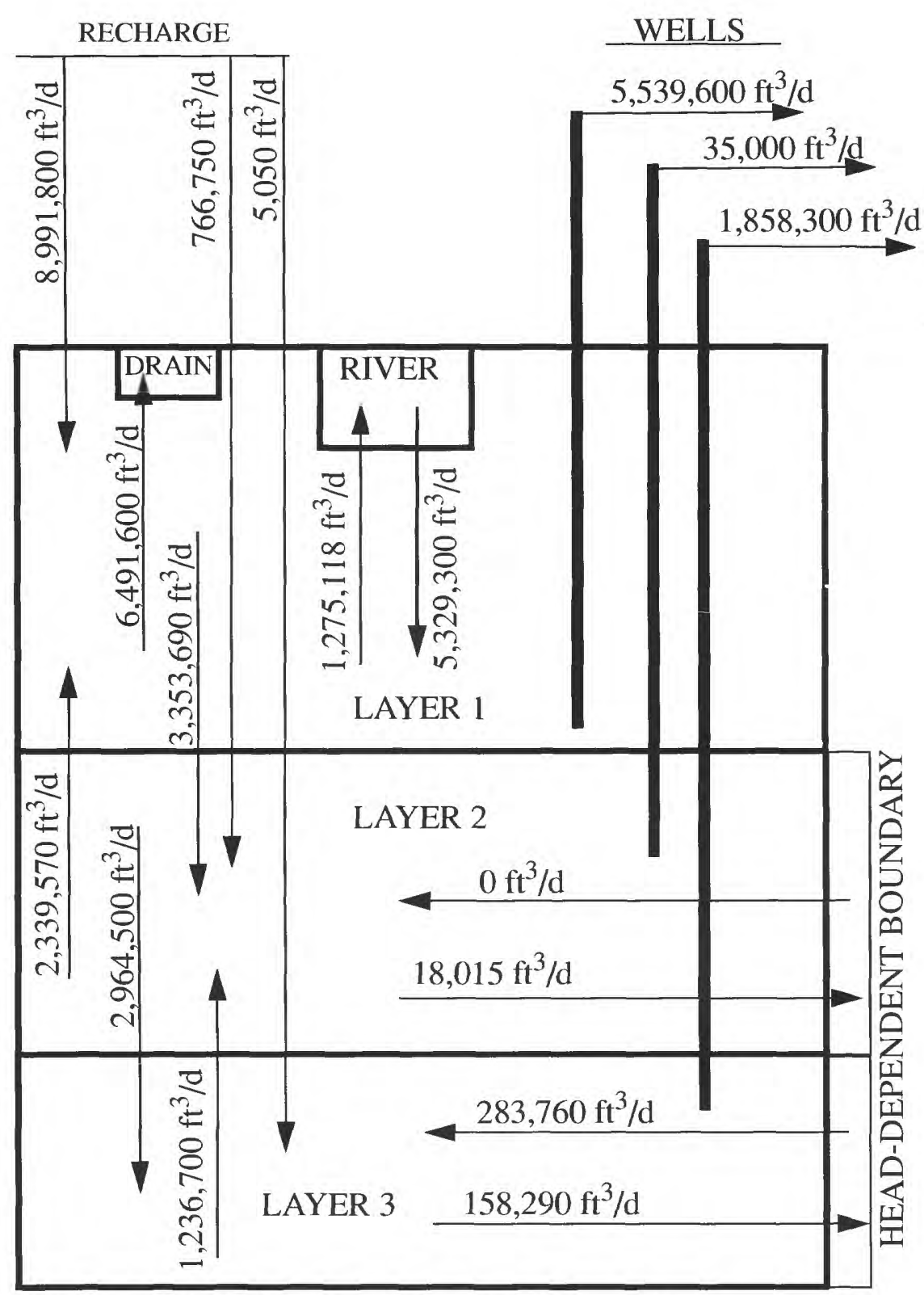

Note: Some numbers for budget components may not add to comparable numbers in table 5 due to rounding.

Figure 19. Model-calculated water-budget components for three layers of ground-water flow model with all wells pumping. All values are in cubic feet per day $\left(\mathrm{ft}^{3} / \mathrm{d}\right)$.

mean annual flow for that water year. To simulate these conditions, model recharge parameters were decreased by 50 percent, and the stage of the river was lowered by $3 \mathrm{ft}$ to simulate the mean measured gage height during October 1988 through September 1989. Results for the less-than-average annual precipitation for 1961-90 scenario (fig. 21) indicate about a 29.0-percent decrease of total volume of ground-water flow for the entire system. The volume of leakage through the drains decreased 61.0 percent, and leakage to the river decreased 25.4 percent. The volume of river leakage to the Cedar River alluvial aquifer increased 5.7 percent, and total ground-water flow to the alluvial aquifer was reduced 32.0 percent compared to the calibrated model results (fig. 19).

The second scenario simulated increased pumping from the Cedar River alluvial aquifer. Simulated pumping was increased from about $41 \mathrm{Mgal} / \mathrm{d}$ in the cali- 
Table 6. Model-calculated water budget for Cedar River alluvial aquifer under presumed steady-state conditions [ft ${ }^{3} / \mathrm{d}$, cubic feet per day; $>$, greater than]

\begin{tabular}{|c|c|c|c|c|c|}
\hline \multirow[b]{2}{*}{ Water-budget components } & \multicolumn{2}{|c|}{$\begin{array}{l}\text { Simulated inflow to } \\
\text { Cedar River alluvial aquifer }\end{array}$} & \multicolumn{2}{|c|}{$\begin{array}{l}\text { Simulated outflow from } \\
\text { Cedar Rlver alluvlal aqulfer }\end{array}$} & \multirow{2}{*}{$\begin{array}{c}\begin{array}{c}\text { Difference } \\
\text { between simu- } \\
\text { lated inflow } \\
\text { and outflow } \\
\text { volumes }\end{array} \\
\begin{array}{c}\text { Inflow-outflow } \\
\left(\mathrm{ft}^{3} / \mathrm{d}\right)\end{array}\end{array}$} \\
\hline & $\begin{array}{l}\text { Inflow } \\
\left(\mathrm{ft}^{3} / \mathrm{d}\right)\end{array}$ & $\begin{array}{l}\text { Percentage } \\
\text { of total } \\
\text { inflow }\end{array}$ & $\begin{array}{l}\text { Outflow } \\
\left(f t^{3} / d\right)\end{array}$ & $\begin{array}{l}\text { Percentage } \\
\text { of total } \\
\text { outflow }\end{array}$ & \\
\hline Infiltration of precipitation & 347,300 & 4.9 & $\mathbf{0}$ & $\mathbf{0}$ & 347,350 \\
\hline River leakage & $5,271,200$ & 74.2 & 975,500 & 13.7 & $4,295,700$ \\
\hline Drain leakage & 0 & 0 & 165,000 & 2.3 & $-165,000$ \\
\hline Pumpage & $\mathbf{0}$ & $\mathbf{0}$ & $5,533,600$ & 78.0 & $-5,533,600$ \\
\hline Head-dependent boundaries & 0 & 0 & 0 & 0 & 0 \\
\hline \multicolumn{6}{|c|}{ Leakage from adjacent hydrogeologic units: } \\
\hline Glacial till aquifer & 108,570 & 1.5 & 1,675 & $>.1$ & 106,895 \\
\hline Eolian-sand-covered glacial till aquifer & 33,708 & .5 & 0 & 0 & 33,708 \\
\hline Loess-covered glacial till aquifer & 10,943 & .2 & 0 & 0 & 10,943 \\
\hline $\begin{array}{l}\text { Cedar River alluvial aquifer overlying } \\
\text { glacial till aquifer }\end{array}$ & 253,420 & 3.6 & 53,340 & .8 & 200,080 \\
\hline Stream alluvial aquifer & 22,220 & .3 & 5,267 & $>.1$ & 16,953 \\
\hline $\begin{array}{l}\text { Layer } 2 \\
\text { (Devonian aquifer, weathered portion of } \\
\text { the confining unit, and the bur- } \\
\text { ied-channel aquifer) }\end{array}$ & $1,050,000$ & 14.8 & 362,500 & 5.1 & 687,500 \\
\hline Totals & 17,097,400 & 100.0 & 17,096,900 & 100.0 & \\
\hline
\end{tabular}

${ }^{1}$ Numbers in columns do not add to totals due to rounding.

brated model to about $70 \mathrm{Mgal} / \mathrm{d}$ in the Cedar River alluvial aquifer. The Cedar Rapids Water Department has proposed to replace groups of vertical wells with horizontal collector wells as the need arises to meet increased demand (John North, Cedar Rapids Water Department, written commun., 1996). The two existing horizontal collector wells are each capable of withdrawing between 7 to $10 \mathrm{Mgal} / \mathrm{d}$ from the Cedar River alluvial aquifer, equivalent to five vertical wells each. Five hypothetical collector wells were added to the calibrated model replacing selected vertical wells to achieve a hypothetical increase in pumping. The location of these hypothetical wells was determined in consultation with the Cedar Rapids Water Department. Each collector well was assigned to an appropriate model cell. Two collector wells were located across the Cedar River from the Seminole Well Field (fig. 3) one collector well west of Seminole 10 (site 40) and the other collector well south of Seminole 18 (site 48) to simulate the collector wells installed in 1995. One collector well was located in the West Well Field (fig. 4) replacing West 7 (site 26), West 8 (site 27), and West 11 (site 30). One collector well was located in the East Well Field (fig. 5) replacing East 1 (site 1), East 2 (site 2), East 6 (site 6), East 8 (site 7), and East 9 (site 8). The fifth collector well was located in the Seminole Well Field (fig. 3) replacing Seminole 1 (site 31), Seminole 2 (site 32), Seminole 3 (site 33), and Seminole 11 (site 41).

Water-budget results for the increased pumping scenario (table 7) indicate about a 68.3-percent increase in pumping volume from $5,533,600 \mathrm{ft}^{3} / \mathrm{d}$ (about $41 \mathrm{Mgal} / \mathrm{d}$ ) in the calibrated model to $9,313,900 \mathrm{ft}^{3} / \mathrm{d}$ (about $70 \mathrm{Mgal} / \mathrm{d}$ ). The simulated inflow from river leakage to the Cedar River alluvial aquifer increased 70.8 percent from $5,271,200 \mathrm{ft}^{3} / \mathrm{d}$ in the calibrated model to $9,007,000 \mathrm{ft}^{3} / \mathrm{d}$ for this scenario. 


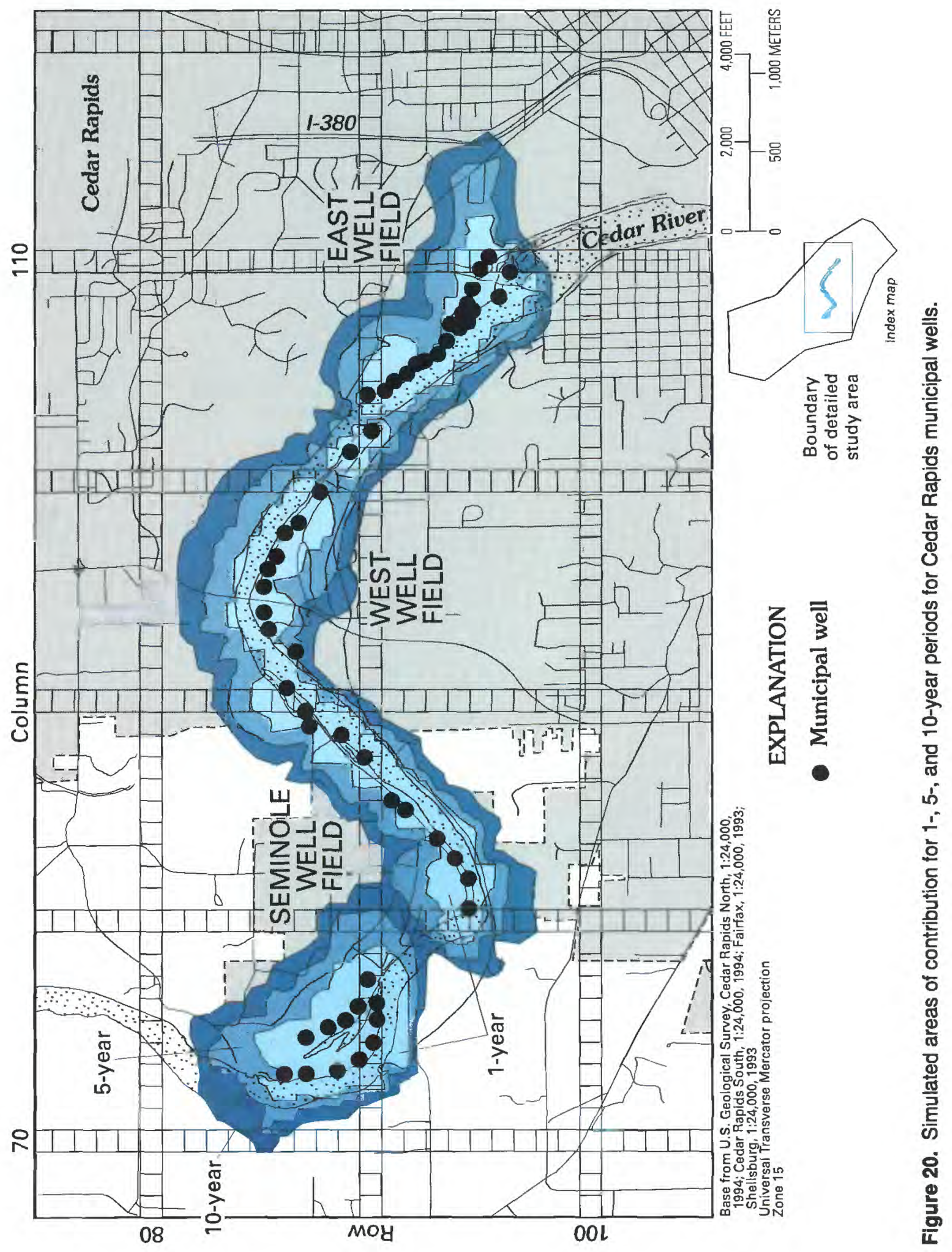




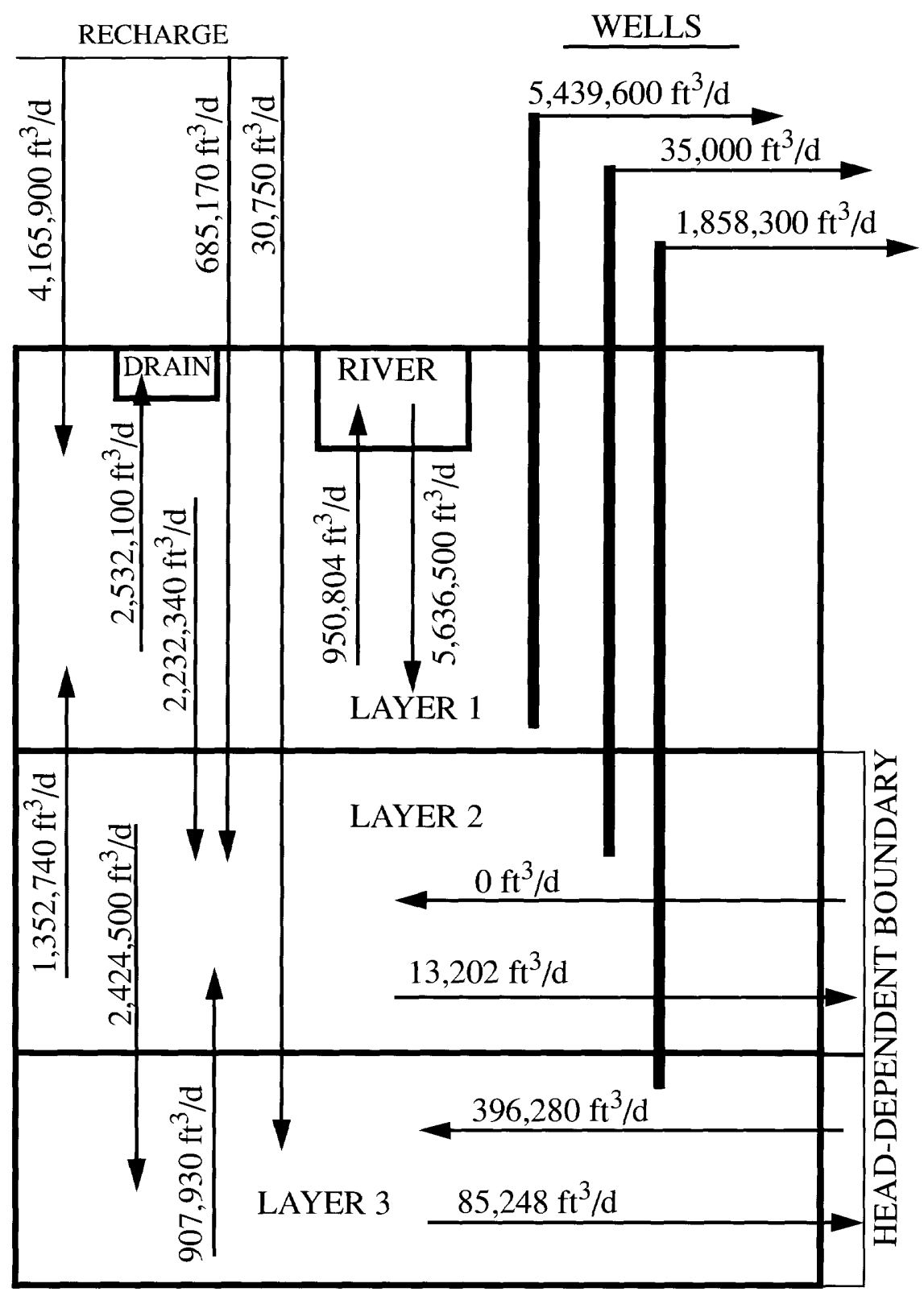

Figure 21. Model-calculated water-budget components for three layers of ground-water flow model with wells pumping for less-than-average annual precipitation for 1961-90 scenario. All values are in cubic feet per day $\left(\mathrm{ft}^{3} / \mathrm{d}\right)$.

Simulated pumping by municipal wells from the Cedar River alluvial aquifer for the increased pumping scenario was $9,313,900 \mathrm{ft}^{3} / \mathrm{d}$, or about $108 \mathrm{ft}^{3} / \mathrm{s}$. By assuming that the simulated difference in inflow and outflow of river leakage was caused by pumping, the model indicates that induced river leakage could contribute about 86 percent of pumping volumes $\left(8,022,630 \mathrm{ft}^{3} / \mathrm{d}\right.$ divided by $9,313,900 \mathrm{ft}^{3} / \mathrm{d}$, table 7$)$. Induced river leakage of about $93 \mathrm{ft}^{3} / \mathrm{s}\left(108 \mathrm{ft}^{3} / \mathrm{s}\right.$ multiplied by 0.86 ) for the increased pumping scenario represents 2.5 percent of the mean annual flow of the
Cedar River $\left(3,670 \mathrm{ft}^{3} / \mathrm{s}\right)$ for the increased pumping scenario.

\section{WATER QUALITY IN THE CEDAR RIVER ALLUVIAL AQUIFER AND RECHARGE SOURCES}

An assessment of water quality in the Cedar River, the Cedar River alluvial aquifer, and the Devonian aquifer was an integral part of the study. The water- 
Table 7. Model-calculated water budget for Cedar River alluvial aquifer under presumed steady-state conditions for increased pumping scenario

$\left[\mathrm{ft}^{3} / \mathrm{d}\right.$, cubic feet per day; >, greater than]

\begin{tabular}{|c|c|c|c|c|c|}
\hline \multirow[b]{2}{*}{ Water-budget component } & \multicolumn{2}{|c|}{$\begin{array}{l}\text { Simuiated inflow to } \\
\text { Cedar River ailuviai aquifer }\end{array}$} & \multicolumn{2}{|c|}{$\begin{array}{l}\text { Simuiated outfiow from } \\
\text { Cedar River ailuviai aquifer }\end{array}$} & \multirow{2}{*}{$\begin{array}{c}\text { Difference } \\
\text { between simu- } \\
\text { lated inflow and } \\
\text { outfiow } \\
\text { voiumes } \\
\text { Infiow-outfiow } \\
\left(\mathrm{ft}^{3} / \mathrm{d}\right)\end{array}$} \\
\hline & $\begin{array}{l}\text { infiow } \\
\left(\mathrm{ft}^{3} / \mathrm{d}\right)\end{array}$ & $\begin{array}{l}\text { Percentage } \\
\text { of total }\end{array}$ & $\begin{array}{l}\text { Outfiow } \\
\left(\mathrm{ft}^{3} / \mathrm{d}\right)\end{array}$ & $\begin{array}{l}\text { Percentage } \\
\text { of total }\end{array}$ & \\
\hline Infiltration of precipitation & 347,300 & 3.2 & 0 & 0 & 347,300 \\
\hline River leakage & $9,007,000$ & 82.7 & 984,370 & 9.0 & $8,022,630$ \\
\hline Drain leakage & 0 & 0 & 128,850 & 1.2 & $-128,850$ \\
\hline Pumpage & 0 & 0 & $9,313,900$ & 85.5 & $-9,313,900$ \\
\hline Head-dependent boundaries & 0 & 0 & 0 & 0 & 0 \\
\hline \multicolumn{6}{|c|}{ Leakage from adjacent hydrogeologic units: } \\
\hline Glacial till aquifer & 107,750 & 1.0 & 1,674 & $>.1$ & 106,076 \\
\hline Eolian-sand-covered glacial till aquifer & 34,399 & .3 & 11 & $>.1$ & 34,388 \\
\hline Loess-covered glacial till aquifer & 11,277 & .1 & 0 & 0 & 11,277 \\
\hline $\begin{array}{l}\text { Cedar River alluvial aquifer over gla- } \\
\text { cial till aquifer }\end{array}$ & 253,850 & 2.3 & 53,770 & .5 & 200,080 \\
\hline Stream alluvial aquifer & 22,779 & .2 & 4,908 & $>.1$ & 17,871 \\
\hline $\begin{array}{l}\text { Layer } 2 \\
\text { (Devonian aquifer, weathered portion of } \\
\text { the confining unit, and the bur- } \\
\text { ied-channel aquifer) }\end{array}$ & $1,111,500$ & 10.2 & 407,820 & 3.7 & 703,680 \\
\hline Totals & ${ }_{10,896,000}$ & 100.0 & ${ }^{1} 10,895,000$ & 100.0 & \\
\hline
\end{tabular}

${ }^{1}$ Numbers in columns do not add to totals due to rounding.

quality assessment includes samples collected to determine spatial water-quality variability (synoptic sampling), temporal water-quality trends (intensive sampling), and the effect of recharge, or leakage, from the Cedar River and the Devonian aquifer on water quality in the Cedar River alluvial aquifer. Inorganic and organic chemical data, continuous multiprobe monitoring, geochemical modeling, and isotopes were among the techniques used for this water-quality assessment. In addition, the water-quality information also can be used to substantiate the interpretation of the ground-water flow system derived from hydraulic analysis. The physical characteristics and constituent concentrations for major ions, nutrients, iron, manganese, dissolved organic carbon, and herbicides in surface-water and ground-water samples collected from October 1992 through March 1996 are presented in Schnoebelen and Schulmeyer (1996).

\section{Synoptic Sampling}

Surface- and ground-water samples were collected in a one-time sampling survey (synoptic sampling) during November 1993. Analytical results were used to assess the water quality of the Cedar River alluvial aquifer in the detailed area of study (fig. 1). During the synoptic sampling, ground-water samples were collected from 64 municipal, observation, domestic, and industrial wells and one surface-water sample was collected from the Cedar River at Edgewood Road Bridge (site 702, fig. 2). Water samples collected from wells screened in the Cedar River alluvial aquifer for the synoptic study included: 36 small-diameter observation wells, 6 observation wells, and 16 municipal wells. Water samples collected from six wells screened in the Devonian and Silurian aquifers for the synoptic study included: four domestic wells, one industrial well, and one observation well. 


\section{Major lons}

The composition of most surface- and groundwater samples can be closely approximated by three major cation and anion groups. Major cations are calcium, magnesium, and sodium plus potassium, and major anions are bicarbonate plus carbonate, sulfate, and chloride. Major ion data indicate that the ground-water samples collected from the Cedar River alluvial, Devonian, and Silurian aquifers are a calcium magnesium bicarbonate type.

\section{Herbicides and Nutrients}

Herbicide concentrations are commonly larger in streams and rivers in Iowa during late spring and early summer than during other seasons as a result of herbicide application in early spring and rainfall runoff (Thurman and others, 1991). A synoptic sampling for herbicides during the fall would expect to find smaller concentrations of herbicides in the aquifer compared to results from late spring and early summer. Commonly used herbicides in Iowa, such as atrazine (and the metabolite products deethylatrazine and deisopropylatrazine), cyanazine, and metolachlor, when detected in the Cedar River alluvial aquifer, were typically at concentrations less than $1.0 \mu \mathrm{g} / \mathrm{L}$. Atrazine concentrations in 26 of the 64 wells sampled were less than the $0.05-\mu \mathrm{g} / \mathrm{L}$ MRL (table 8). Atrazine concentrations detected in water samples collected from 38 wells ranged from 0.06 to $1.8 \mu \mathrm{g} / \mathrm{L}$ with a mean of $0.38 \mu \mathrm{g} / \mathrm{L}$, an order of magnitude smaller than the MCL of $3.0 \mu \mathrm{g} / \mathrm{L}$ for atrazine (U.S. Environmental Protection Agency, 1986) (table 8). Concentrations of alachor, ametryn, metribuzin, prometon, prometryn, propazine, simazine, and terbutryn were less than the $0.05-\mu \mathrm{g} / \mathrm{L}$ MRL for samples from the Cedar River alluvial aquifer (Schnoebelen and Schulmeyer, 1996). Herbicide concentrations were less than $0.05 \mu \mathrm{g} / \mathrm{L}$ for most ground-water samples collected from the Devonian and Silurian aquifers. Two atrazine metabolites (the breakdown products of atrazine), deethylatrazine and deisopropylatrazine, were detected at concentrations of 0.09 and $0.07 \mu \mathrm{g} / \mathrm{L}$, respectively, in one sample collected from the Devonian and Silurian aquifers (site 635, table 2 in Schnoebelen and Schulmeyer, 1996). A deisopropylatrazine concentration of 0.10 $\mu \mathrm{g} / \mathrm{L}$ was found in another sample collected from the Devonian and Silurian aquifers (site 625, table 2 in Schnoebelen and Schulmeyer, 1996).

Nitrite plus nitrate nitrogen (nitrate) concentrations in ground-water samples collected for the synoptic sampling varied from less than the MRL $(0.05 \mathrm{mg} / \mathrm{L})$ to $15.0 \mathrm{mg} / \mathrm{L}$ (table 8). Nitrate was not detected in $18 \mathrm{sam}$ ples, and nitrate concentrations between 0.06 and $15.0 \mathrm{mg} / \mathrm{L}$, with a mean of about $3.4 \mathrm{mg} / \mathrm{L}$ (table 8), were detected in samples from 46 wells. Nitrate concentrations in samples from four wells, CRM-SD-20 (site 955), CRM-SD-37A (site 968), CRM-SD-38A (site 970), and CRM-SD-38B (site 971), were greater than the MCL for nitrate as nitrogen $(10 \mathrm{mg} / \mathrm{L}$ ) (U.S. Environmental Protection Agency, 1986).

\section{Intensive Sampling}

Water-quality samples were collected about every 3 to 4 months from four observation wells and two municipal wells in the Seminole Well Field in the Cedar River alluvial aquifer, two observation wells completed in the Devonian aquifer, and the Cedar River to assess water-quality trends (fig. 22). The two intensive study sites were used to determine the relation between the Cedar River alluvial aquifer, the Cedar River, and the Devonian aquifer in terms of water quality and flow. Constituents analyzed for at the intensive study sites included physical characteristics, major ions, nutrients, and herbicides. The physical characteristics (specific conductance, $\mathrm{pH}$, water temperature, and dissolved oxygen) were continuously collected by multiprobe instruments.

Intensive study sites are located near municipal wells Seminole 10 (site 40) and Seminole 1 (site 31) (fig. 22). At the intensive study site near municipal well Seminole 10 (site 40), multiprobes were installed in the Cedar River, in observation wells CRM-3 (site 918), CRM-4 (site 919), and municipal well Seminole 10 (site 40) completed in the alluvial aquifer, and in observation well CRM-6 (site 986) completed in the Devonian aquifer. Data were collected at this site from December 1992 through January 1994. The multiprobes then were moved to the second intensive site near municipal well Seminole 1 (site 31). Data were collected at this site from June 1994 through February 1996. The multiprobes at the second site were installed in the observation wells CRM-9 (site 992), CRM-10 (site 993), municipal well Seminole 1 (site 31) completed in the alluvial aquifer, and observation well CRM-7 (site 990) completed in the Devonian aquifer. The multiprobe in the Cedar River remained at municipal well Seminole 10 (site 40) during data collection at both intensive study sites. 
Table 8. Herbicide and nutrient concentrations in ground-water samples collected during synoptic sampling of Cedar River alluvial, Devonian, and Silurian aquifers, November 1993

[mg/L, milligrams per liter, $\mu \mathrm{g} / \mathrm{L}$, micrograms per liter; ND, no detection, ND values are less than the minimum reporting level for that constituent, which was less than $0.05 \mu \mathrm{g} / \mathrm{L}$ for pesticides, less than $0.05 \mathrm{mg} / \mathrm{L}$ for nitrite plus nitrate as nitrogen, and less than $0.01 \mathrm{mg} / \mathrm{L}$ for ammonia as nitrogen, nitrate as nitrogen, and orthophosphorus ${ }^{1}$ ]

\begin{tabular}{lcccc}
\hline \multicolumn{1}{c}{ Constituent } & $\begin{array}{c}\text { Minimum } \\
\text { value detected }\end{array}$ & $\begin{array}{c}\text { Maximum } \\
\text { value detected }\end{array}$ & $\begin{array}{c}\text { Mean value } \\
\text { detected }\end{array}$ & $\begin{array}{c}\text { Number of } \\
\text { detecting total } \\
\text { number of wells } \\
\text { sampled }\end{array}$ \\
\hline Alachlor $(\mu \mathrm{g} / \mathrm{L})$ & $\mathrm{ND}$ & $\mathrm{ND}$ & $\mathrm{ND}$ & $0 / 64$ \\
Ametryn $(\mu \mathrm{g} / \mathrm{L})$ & $\mathrm{ND}$ & $\mathrm{ND}$ & $\mathrm{ND}$ & $0 / 64$ \\
Atrazine $(\mu \mathrm{g} / \mathrm{L})$ & .06 & 1.8 & .38 & $38 / 64$ \\
Cyanazine $(\mu \mathrm{g} / \mathrm{L})$ & .07 & .13 & .09 & $8 / 64$ \\
Deethylatrazine $(\mu \mathrm{g} / \mathrm{L})$ & .07 & .47 & .23 & $37 / 64$ \\
& & & & \\
Deisopropylatrazine $(\mu \mathrm{g} / \mathrm{L})$ & .06 & 1.9 & .22 & $35 / 64$ \\
Metolachlor $(\mu \mathrm{g} / \mathrm{L})$ & .06 & .38 & .12 & $25 / 64$ \\
Metribuzin $(\mu \mathrm{g} / \mathrm{L})$ & $\mathrm{ND}$ & $\mathrm{ND}$ & $\mathrm{ND}$ & $0 / 64$ \\
Prometon $(\mu \mathrm{g} / \mathrm{L})$ & $\mathrm{ND}$ & $\mathrm{ND}$ & $\mathrm{ND}$ & $0 / 64$ \\
Prometryn $(\mu \mathrm{g} / \mathrm{L})$ & .1 & .1 & .1 & $1 / 64$ \\
& & & & \\
Propazine $(\mu \mathrm{g} / \mathrm{L})$ & $\mathrm{ND}$ & $\mathrm{ND}$ & $\mathrm{ND}$ & $0 / 64$ \\
Simazine $(\mu \mathrm{g} / \mathrm{L})$ & $\mathrm{ND}$ & $\mathrm{ND}$ & $\mathrm{ND}$ & $0 / 64$ \\
Terbutryn $(\mu \mathrm{g} / \mathrm{L})$ & $\mathrm{ND}$ & $\mathrm{ND}$ & $\mathrm{ND}$ & $0 / 64$ \\
Nitrite as nitrogen $(\mathrm{mg} / \mathrm{L})$ & .01 & .04 & .02 & $18 / 64$ \\
Nitrite plus nitrate as nitrogen $(\mathrm{mg} / \mathrm{L})$ & .06 & 15 & 3.4 & $46 / 64$ \\
Ammonia as nitrogen $(\mathrm{mg} / \mathrm{L})$ & .01 & 7.8 & .37 & $55 / 64$ \\
& & & & \\
Phosphorous, ortho $(\mathrm{mg} / \mathrm{L})$ & .01 & .47 & .06 & $56 / 64$ \\
\hline
\end{tabular}

${ }^{1}$ Timme (1995).

The two intensive sites allowed water-quality monitoring of slightly different depositional environments within the Cedar River alluvial aquifer. Data from drill cuttings indicated that the aquifer material near municipal well Seminole 10 (site 40 ) is a clean, coarsegrained sand and that the aquifer material near municipal well Seminole 1 (site 31 ) is an argillaceous, fine-grained sand.

Specific conductance of water and water temperature from the observation wells displayed trends similar to that of water from the Cedar River, indicating that both can be used to determine a traveltime for water from the Cedar River to observation and municipal wells. Specific-conductance data indicated that the time of travel from the Cedar River to observation well CRM-4 (site 919) was about 4 to 5 days and to municipal well Seminole 10 (site 40 ) about 7 to 12 days (Schulmeyer, 1995). Ground-water traveltime from the river to observation well CRM-3 (site 918) was estimated at 29 days (Schulmeyer, 1995).

\section{Water Temperature}

Surface water is subject to seasonal fluctuations of temperature caused by changes in air temperaturecolder in the winter and warmer in the summer, whereas ground-water temperatures are typically more stable throughout the year. A plot of water temperature from February 1993 through January 1994 for water from the Cedar River and observation wells CRM-3 (site 918) and CRM-4 (site 919) at the intensive study site near municipal well Seminole 10 (site 40) showed contrasting trends (fig. 23). The temperature trend for water from observation well CRM-4 (site 919) is similar to the temperature trend for water from the Cedar River, whereas the temperature trend for water from observation well CRM-3 (site 918) is different 

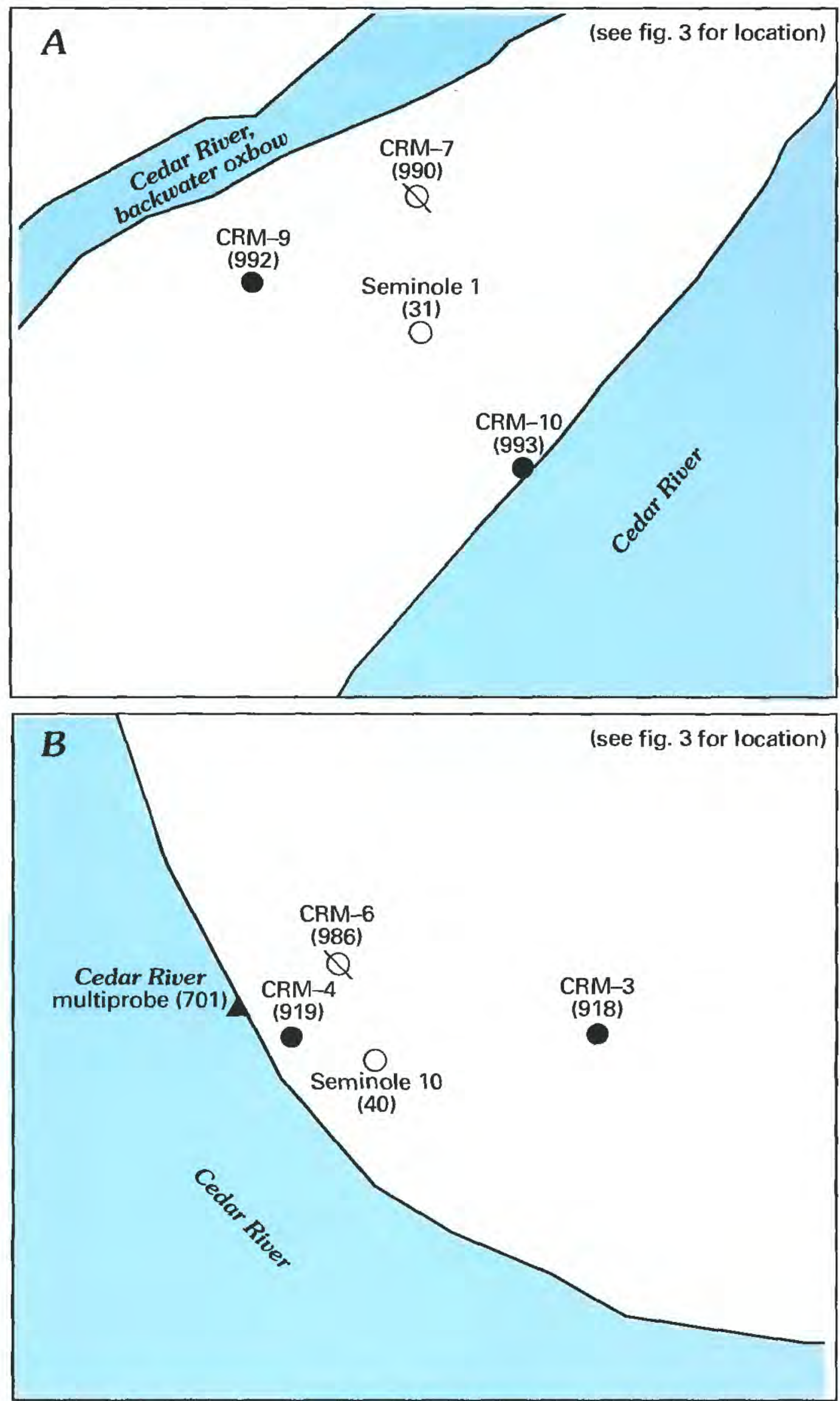

\section{NOT TO SCALE EXPLANATION}

CRIM-9

(992) Alluvial observation well and name-Number in parentheses () is site number used in table 12

Seminole

(31) Municipal well and name-Number in parentheses () is site number used in table 12

CRM-6

(986) $Q$ Bedrock observation well and name-Number in parentheses () is site Cedar River multiprobe (701) number used in table 12

Surface-water-quality data-collection site and name-Number in parentheses ( ) is site number used in table 12

Figure 22. Features of intensive study sites near Cedar Rapids municipal wells (A) Seminole 1 and (B) Seminole 10. 


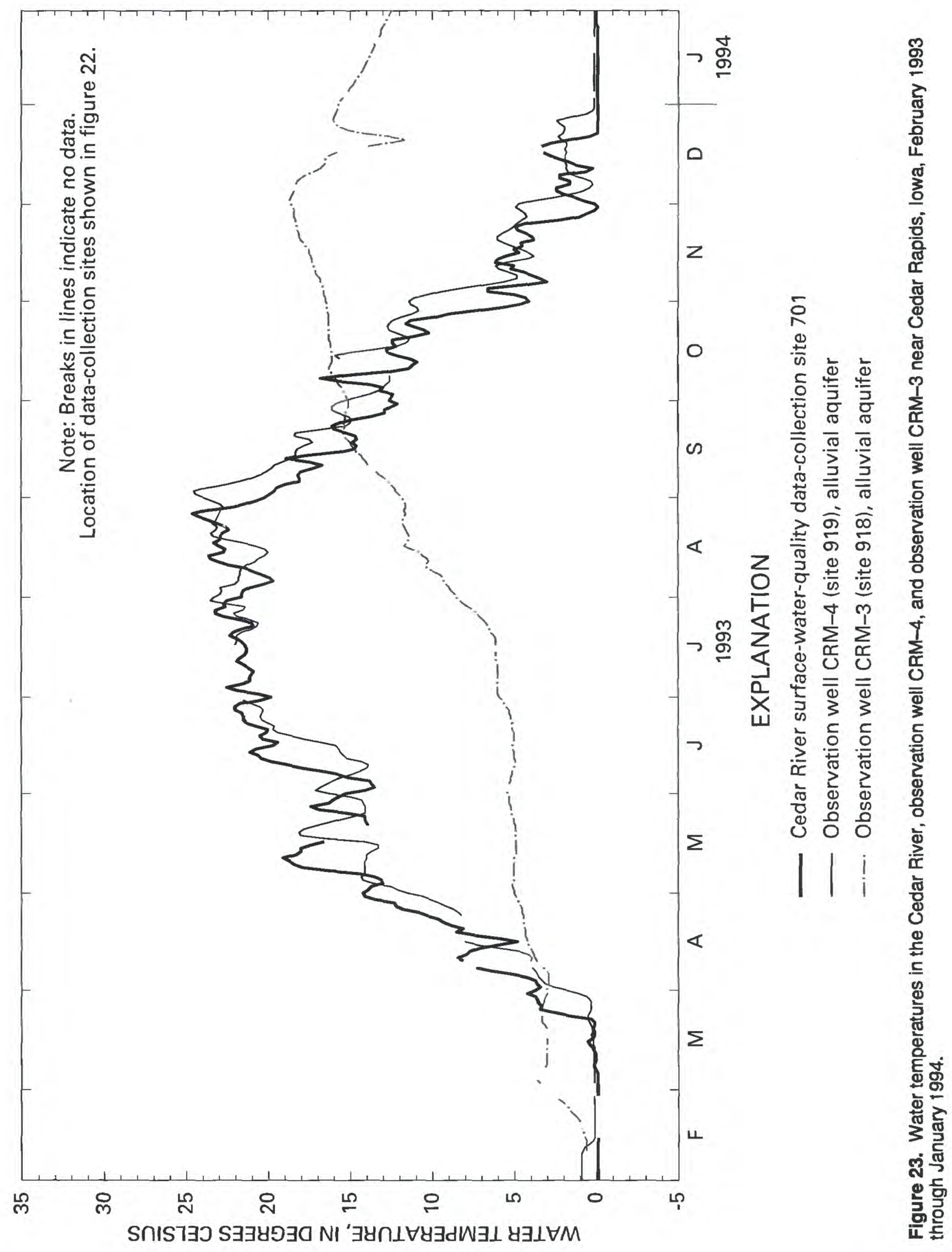


(fig. 23). Pumping of municipal well Seminole 10 (site 40) induces infiltration of water from the Cedar River into the Cedar River alluvial aquifer and from upland areas. On December 25, 1993, water levels were $718.10 \mathrm{ft}$ in the Cedar River, $715.41 \mathrm{ft}$ in observation well CRM-4 (site 919), $715.86 \mathrm{ft}$ in observation well CRM-3 (site 918), and $700.87 \mathrm{ft}$ in municipal well Seminole 10 (site 40). The gradient from the Cedar River to municipal well Seminole 10 (site 40) was 0.36 . The gradient from observation well CRM-4 (site 919) to municipal well Seminole 10 (site 40 ) was 0.66 and from observation well CRM-3 (site 918) was 0.26 . The water passing observation well CRM-4 (site 919) from the river to Seminole well 10 (site 40 ) had little time to mix or equilibrate with the aquifer material or other water in the alluvial aquifer and is thus indicative of the Cedar River.

Conversely, temperature of water from observation well CRM-3 (site 918) did not correlate with temperature of water from observation well CRM-4 (site 919) (fig. 23) or the Cedar River. The temperature of water from observation well CRM-3 (site 918) indicated recharge from infiltration of precipitation rather than recharge from the river. The change in water temperature indicated that induced infiltration from the Cedar River was not affecting the aquifer near observation well CRM-3 (site 918) as much as at observation well CRM-4 (site 919). Rainfall occurs during the summer months and recharges the Cedar River alluvial aquifer as infiltration of precipitation. In particular, record amounts of rainfall fell in Iowa during the summer of 1993 (Parrett and others, 1993). The mass of recharge water moved downgradient toward the river, and there was a lag time of 1 to 3 months from when the warmer water first entered the aquifer to when it was measured in observation well CRM-3 (site 918). An approximate lag time can be estimated by assuming that the temperature of water from the Cedar River responded quickly to changes in temperature of water from precipitation. Therefore, the ground-water temperatures observed in December in the Cedar River alluvial aquifer at observation well CRM-3 (site 918) correspond to surface-water temperatures at the end of August. Schneider (1962) observed lag times of 1.5 to 5 months between air temperatures and water temperatures in an alluvial aquifer in Minnesota.

Temperatures of water from the Cedar River and observation wells CRM-9 (site 992) and CRM-10 (site 993) at the intensive study site near municipal well Seminole 1 (site 31) are shown in figure 24.
Temperature of water from observation well CRM-10 (site 993) was similar to the temperature of water from the Cedar River during 1994. The fine-grained sediment observed when drilling near municipal well Seminole 1 (site 31 ) could cause a slower response time between observation well CRM-10 (site 993) and the Cedar River. The similarity in water temperatures from observation wells CRM-10 (site 993) and CRM-9 (site 992) during 1995 occurred because municipal well Seminole 1 (site 31) was not pumping for much of this time period, and there were no effects caused by induced recharge from the river after about December 1994. Rather, the effect of ground-water recharge to the Cedar River was observed. Water temperatures in observation wells CRM-10 (site 993) and CRM-9 (site 992) are representative of ground-water temperature when pumping does not occur.

\section{Specific Conductance}

The specific-conductance values of water from observation well CRM-4 (site 919) followed the trend of specific-conductance values of water from the Cedar River (approximately 400 to $600 \mu \mathrm{S} / \mathrm{cm}$ ). The specific-conductance values of water from observation well CRM-3 (site 918) did not follow the trend of specific-conductance values of water from the Cedar River. It was difficult to correlate increases and decreases of values between observation well CRM-3 (site 918) and the Cedar River. This lack of correlation indicates a lesser effect by river leakage at observation well CRM-3 (site 918) on specific conductance than at observation well CRM-4 (site 919). Specific-conductance values measured in water from observation well CRM-3 (site 918) tended to be larger than specific-conductance values measured in water from observation well CRM-4 (site 919) and the Cedar River and indicate a lesser effect from river leakage at greater distances from the river. Larger concentrations of dissolved solids in upgradient ground water in the Cedar River alluvial aquifer are indicative of a longer contact time with the aquifer materials.

The specific-conductance values for water from observation well CRM-10 (site 993) near municipal well Seminole 1 (site 31 ) were similar to specific-conductance values for water from the Cedar River. In contrast, specific-conductance values for water from observation well CRM-9 (site 992) were consistently larger (mean of $817 \mu \mathrm{S} / \mathrm{cm}$ ) than values of water from the Cedar River (mean of $475 \mu \mathrm{S} / \mathrm{cm}$ ) for June 1994 through January 1996 (Schnoebelen and Schulmeyer, 


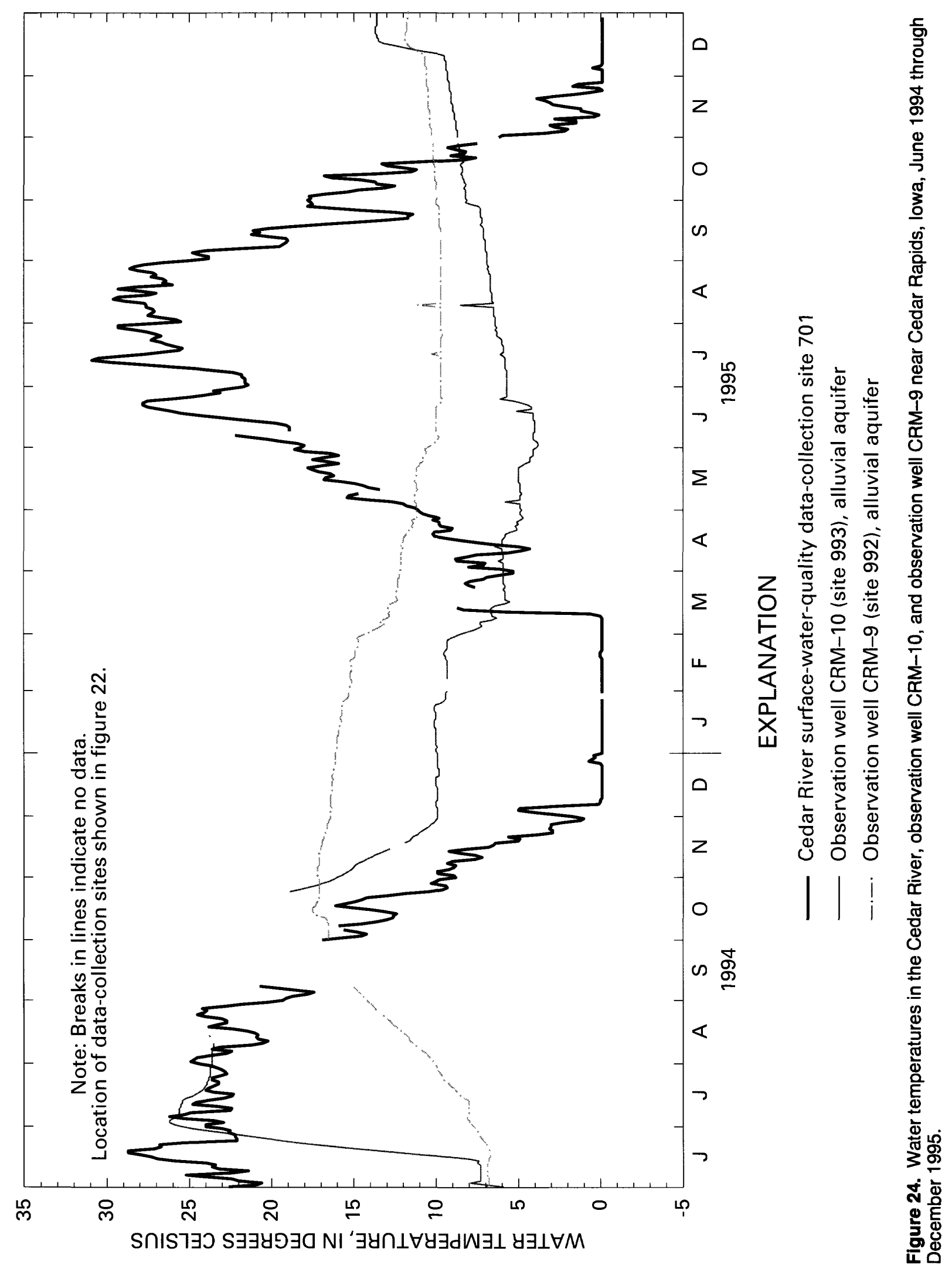


1996). The large specific-conductance values measured for water from observation well CRM-9

(site 992) indicate a lesser effect from river leakage at greater distances from the main channel of the river and that upgradient ground water has a longer contact time with aquifer materials.

\section{Major Ions and Metals}

The major ion concentrations in water samples collected from wells from March 1993 through January 1996 at the intensive study sites were similar to those found during the synoptic sampling (Schnoebelen and Schulmeyer, 1996, table 2). Temporal variations in concentration for any particular ion were typically small (less than 10 to 20 percent). However, iron and manganese tended to show large variations (often an order of magnitude) during the sampling period. Iron and manganese reactions will be discussed in the "Iron and Manganese Reactions" section later in this report.

\section{Herbicides and Nutrients}

Water samples from the two intensive study sites were collected every 3 to 4 months (1992 through 1996) and analyzed for herbicides and nutrients to detect trends in concentration and occurrence in the Cedar River and the Cedar River alluvial aquifer. The fate and transport of herbicides and nutrients between the river and the Cedar River alluvial aquifer are complex and may include adsorption, oxidation-reduction reactions, and microbial degradation. The details of these reactions were beyond the scope of this study.

Herbicide concentrations in samples collected at the two intensive study sites were less than the MCLs (U.S. Environmental Protection Agency, 1986). Selected herbicide concentrations in water collected from municipal wells Seminole 10 (site 40) and Seminole 1 (site 31), the municipal water plant, and the Cedar River are listed in table 9. Analytical results for ametryn, metribuzin, prometon, prometryn, propazine, and terbutryn, which are not listed in table 9, were all less than the MRL of $0.05 \mu \mathrm{g} / \mathrm{L}$. The temporal trend for concentrations of atrazine is typical and similar for the other common herbicides that were detected (fig. 25). Herbicide concentrations generally were greater after the spring runoff in both the Cedar River and ground water from the Cedar River alluvial aquifer. However, the herbicide concentrations in the ground water from the Cedar River alluvial aquifer during the spring and early summer runoff were much less than in the Cedar River. For example, the atrazine concentration for the June 1994 sample was $5.3 \mu \mathrm{g} / \mathrm{L}$ in the Cedar River, $0.86 \mu \mathrm{g} / \mathrm{L}$ in municipal well Seminole 10 (site 40), and $0.14 \mu \mathrm{g} / \mathrm{L}$ in municipal well Seminole 1 (site 31) (table 9).

Nutrient concentrations in ground-water samples collected at the intensive sites were similar to or less than concentrations collected during the synoptic sampling. Nitrate was not detected at concentrations greater than the MCL $(10.0 \mathrm{mg} / \mathrm{L})$ in the Cedar River alluvial aquifer at the intensive study sites (table 9 in this report and table 2 in Schnoebelen and Schulmeyer, 1996).

\section{Mineral Equilibria}

Mineral equilibria were studied to better understand possible chemical reactions in the Cedar River alluvial aquifer and to define areas where specific minerals could precipitate and cause well-screen clogging and scaling. The USGS geochemical modeling program WATEQF (Plummer and others, 1976) was used to model the equilibrium between ground water and minerals present in the aquifer system. The computation of the saturation indices $(S I)$ of the minerals is expressed as:

$$
S I_{\text {mineral }}=\log \frac{I A P}{K T},
$$

where IAP is the ion-activity product of the mineral calculated from analytical data, and

$K T$ is the thermodynamic equilibrium constant at the measured temperature of the water sample.

If the saturation index for a particular mineral is negative, the ground water is undersaturated with respect to that mineral, and dissolution may be possible. If the saturation index is positive for a mineral, the ground water is oversaturated with respect to that mineral, and precipitation may be possible. A saturation index of zero indicates that the mineral is in equilibrium with the ground water and that the rates of dissolution and precipitation should be equal. Equilibrium thermodynamics can only indicate the potential for such phase transfers. In reality, there are a number of kinetic reasons that cause systems to behave differently than predicted (Nordstrom and Ball, 1989; Busby and others, 


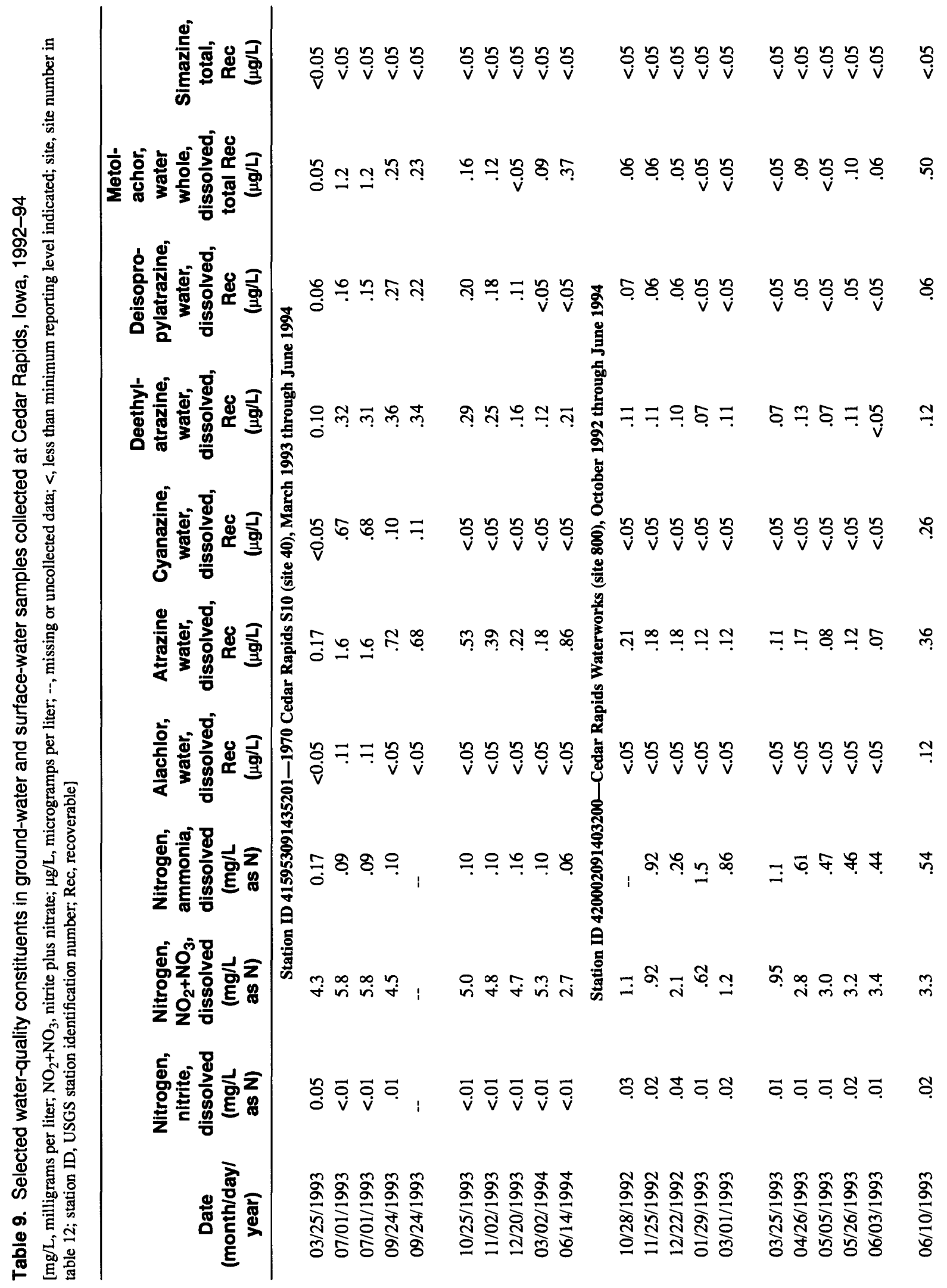




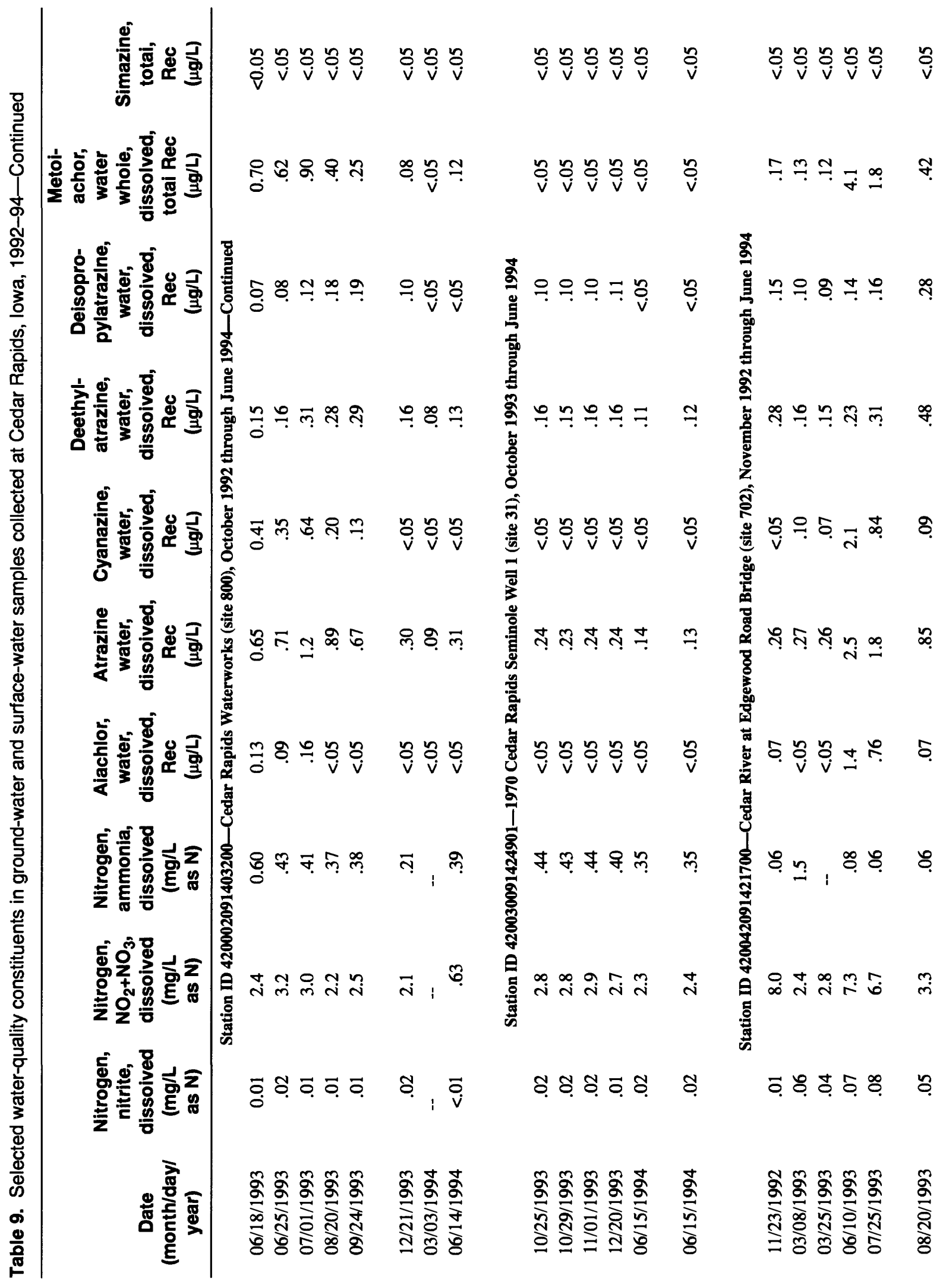




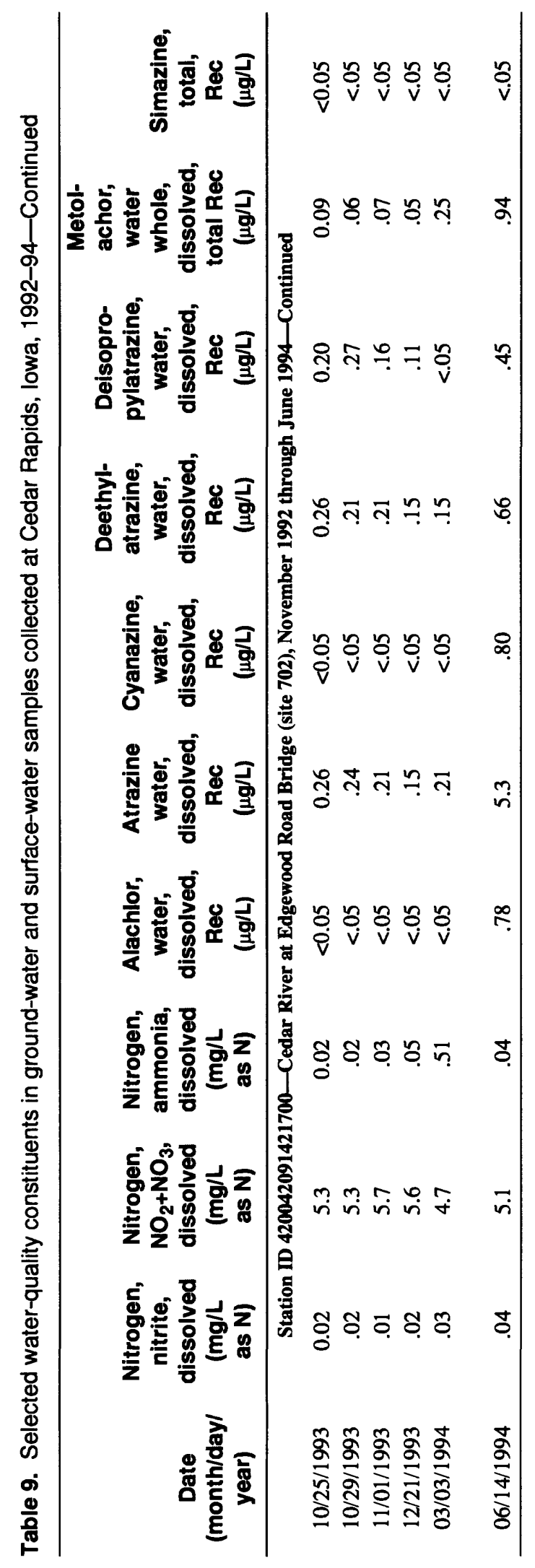




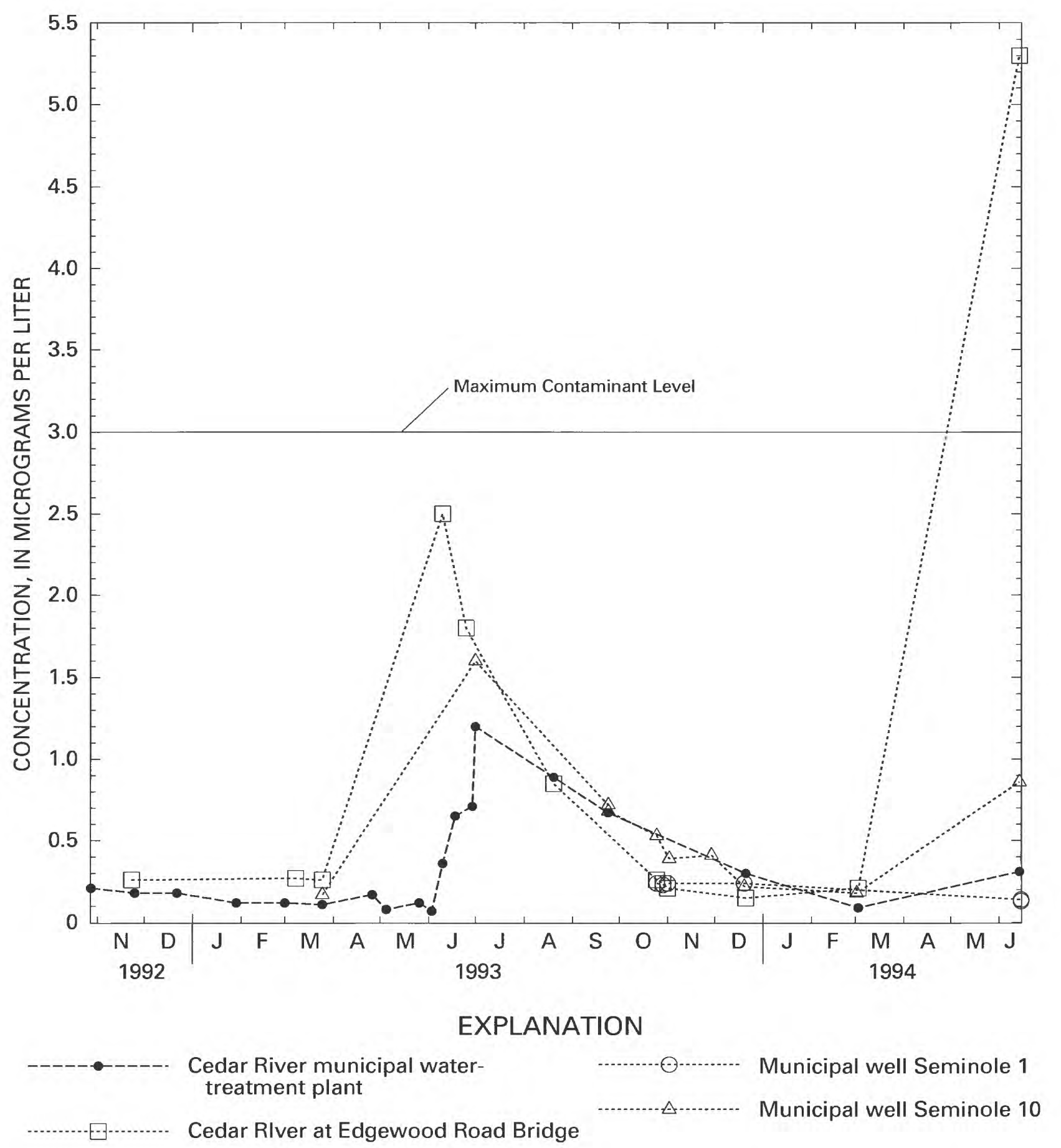

Figure 25. Concentrations of atrazine in water collected from Cedar Rapids municipal water-treatment plant, the Cedar River, and municipal wells Seminole 1 and Seminole 10 from October 1992 through June 1994.

1991). However, saturation indices can help show potential phases and how "aggressive" the water may be in its potential to dissolve minerals or its potential to precipitate minerals. Saturation indices for some common minerals (calcite, $\mathrm{CaCO}_{3}$; dolomite, $\mathrm{CaMg}\left(\mathrm{CO}_{3}\right)_{2}$; ferrihydrite, $\mathrm{FeOH}_{3}$; magnesite,
$\mathrm{MgCO}_{3}$; and manganite, $\mathrm{MnOOH}$ ) for ground-water samples collected during the November 1993 synoptic sampling are listed in table 10.

In general, ground water is in equilibrium or oversaturated with respect to calcite and undersaturated with respect to dolomite throughout the study area. The 
Table 10. Saturation indices for common minerals in water samples collected during synoptic sampling, November 1993 [--, no data]

\begin{tabular}{|c|c|c|c|c|c|c|c|}
\hline $\begin{array}{c}\text { Site } \\
\text { number } \\
\text { (figs. 3-5) }\end{array}$ & $\begin{array}{c}\text { Station } \\
\text { identification } \\
\text { number }\end{array}$ & Local site name & Calcite & Dolomite & $\begin{array}{l}\text { Ferrihy- } \\
\text { drite }\end{array}$ & Magnesite & Manganite \\
\hline 916 & 415949091405401 & CRM-1 & -0.077 & -1.112 & 1.522 & -1.000 & -2.109 \\
\hline 917 & 420033091420301 & CRM-2 & -.203 & -1.524 & 1.342 & -1.195 & -1.471 \\
\hline 918 & 415953091435001 & CRM-3 & .024 & -1.068 & 1.419 & -1.069 & -2.572 \\
\hline 919 & 415953091434301 & CRM-4 & .081 & -.863 & 1.537 & -.854 & -3.327 \\
\hline 920 & 420408091470201 & CRM-5 & .040 & -.855 & 2.510 & -.863 & -2.162 \\
\hline 986 & 415954091435301 & CRM-6 & -.219 & -1.324 & .670 & -1.024 & -4.600 \\
\hline 990 & 420032091424701 & CRM-7 & - & -- & .939 & -- & -2.430 \\
\hline 991 & 420314091452101 & CRM-8 & -.022 & -1.316 & 3.976 & -1.211 & -2.591 \\
\hline 992 & 420032091424901 & CRM-9 & -- & - & 3.226 & - & -2.154 \\
\hline 993 & 420030091424601 & CRM-10 & -- & - & 2.046 & -- & -3.059 \\
\hline 935 & 420357091461301 & CRM-SD-1A & -1.455 & -3.973 & .044 & -2.456 & -6.380 \\
\hline 936 & 420357091461302 & CRM-SD-1B & .108 & -.878 & 2.536 & -.933 & -1.864 \\
\hline 937 & 420403091464602 & CRM-SD-2A & .026 & -1.251 & 1.309 & -1.205 & -3.733 \\
\hline 938 & 420403091464601 & CRM-SD-2B & .085 & -1.033 & 4.340 & -1.047 & -2.682 \\
\hline 941 & 420240091451501 & CRM-SD-4A & .103 & -1.038 & .984 & -1.069 & -4.960 \\
\hline 947 & 420350091453802 & CRM-SD-11B & .096 & -.933 & 3.014 & -.967 & -3.246 \\
\hline 951 & 415953091435002 & CRM-SD-15 & -.209 & -1.387 & 1.671 & -1.166 & -3.756 \\
\hline 952 & 420313091451901 & CRM-SD-17 & .006 & -1.219 & 1.774 & -1.153 & -.710 \\
\hline 953 & 420328091445601 & CRM-SD-18 & -2.011 & -5.258 & -.037 & -3.185 & -5.024 \\
\hline 956 & 420038091443601 & CRM-SD-21A & .191 & -.721 & 4.446 & -.841 & -1.974 \\
\hline 957 & 420038091443602 & CRM-SD-21B & .108 & -.878 & 2.536 & -.933 & -1.864 \\
\hline 960 & 420021091440901 & CRM-SD-29 & -.170 & -1.792 & .970 & -1.550 & -5.765 \\
\hline 962 & 420020091431501 & CRM-SD-31 & .224 & -.528 & .299 & -.733 & -2.219 \\
\hline 967 & 420435091474701 & CRM-SD-36 & .113 & -.893 & 1.716 & -.925 & -4.484 \\
\hline 968 & 420331091454501 & CRM-SD-37A & .091 & -1.096 & .748 & -1.116 & -4.461 \\
\hline 974 & 420345091475601 & CRM-SD-40 & -.048 & -1.223 & .654 & -1.103 & -1.678 \\
\hline 975 & 420000091410001 & CRM-SD-41A & -.240 & -.853 & .688 & -.542 & -4.882 \\
\hline 976 & 420000091410002 & CRM-SD-41B & .199 & -.549 & .718 & -.677 & -4.826 \\
\hline 977 & 420013091430601 & CRM-SD-42 & .719 & .359 & 1.127 & -.247 & -1.782 \\
\hline 978 & 420029091424801 & CRM-SD 43 & .301 & -.373 & 4.230 & -.576 & -1.239 \\
\hline 979 & 415953091435401 & CRM-SD-44 & .564 & .062 & 1.850 & -.396 & -1.473 \\
\hline
\end{tabular}


Table 10. Saturation indices for common minerals in water samples collected during synoptic sampling, November 1993 -Continued

\begin{tabular}{cclccccc}
\hline $\begin{array}{c}\text { Site } \\
\text { number } \\
\text { (figs. 3-5) }\end{array}$ & $\begin{array}{c}\text { Station } \\
\text { identification } \\
\text { number }\end{array}$ & Local site name & Calcite & Dolomite & $\begin{array}{c}\text { Ferrihy- } \\
\text { drite }\end{array}$ & Magnesite & Manganite \\
\hline 9 & 415949091405201 & East 10 & -0.116 & -1.157 & 3.127 & -0.997 & -2.576 \\
11 & 415952091405701 & East 12 & -.029 & -1.032 & 2.403 & -.940 & -2.262 \\
702 & 420042091421700 & Edgewood Road Bridge & .872 & .606 & 2.002 & -.113 & -1.598 \\
624 & 415929091440401 & Martin & .107 & -.901 & 1.500 & -.936 & -4.325 \\
800 & 420002091404200 & Municipal water plant & - & - & 2.535 & -- & -1.986 \\
& & & & & & & \\
328 & 415834091394301 & Pepsi-Cola Plant & .366 & .094 & 2.082 & -.302 & -4.470 \\
31 & 420030091424901 & Seminole 1 & -.050 & -1.109 & 3.293 & -.982 & -1.941 \\
32 & 420025091425801 & Seminole 2 & .250 & -.431 & 2.192 & -.626 & -2.057 \\
33 & 420020091430601 & Seminole 3 & .057 & -.837 & .586 & -.842 & -2.095 \\
34 & 420015091430601 & Seminole 4 & -.014 & -.972 & 2.494 & -.907 & -2.179 \\
& & & & & & & -2.235 \\
36 & 420006091432201 & Seminole 6 & .066 & -.853 & .554 & -.873 & -2.235 \\
38 & 415955091433601 & Seminole 8 & -.088 & -1.175 & 1.034 & -1.037 & -2.432 \\
40 & 415953091435201 & Seminole 10 & .130 & -.699 & .657 & -.772 & -2.287 \\
44 & 420020091442501 & Seminole 14 & -.217 & -1.554 & 3.623 & -1.275 & -3.072 \\
46 & 420029091443001 & Seminole 16 & -.182 & -1.472 & 3.808 & -1.231 & -2.657 \\
\hline
\end{tabular}

carbonate-mineral equilibria could be controlling concentrations of calcium, magnesium, and bicarbonate in the calcium magnesium bicarbonate water. These ions are responsible for the large concentrations of dissolved solids and the hardness in the ground water. Respiration by organisms in the organic-rich soils overlying the Cedar River alluvial aquifer produce an abundant source of carbon dioxide $\left(\mathrm{CO}_{2}\right)$ (in addition to available atmospheric $\mathrm{CO}_{2}$ ) that combines with water to form carbonic acid $\left(\mathrm{H}_{2} \mathrm{CO}_{3}\right)$. The dissociation of carbonic acid produces hydrogen ions and bicarbonate ions. Hydrogen ions are available to cause dissolution of carbonate minerals in the Cedar River alluvial and Devonian aquifers. Carbonate equilibrium probably occurs in the Cedar River alluvial aquifer shortly after infiltration of precipitation. This is indicated by saturation indices for calcite that show approximate equilibrium conditions for samples from shallow observation wells CRM-SD-31 (site 962), CRM-SD-42 (site 977), and CRM-SD-44 (site 979) that were completed at depths from 3 to $18 \mathrm{ft}$. Calcite will have a strong tendency to precipitate in the well screen particularly with increased turbulence and oxygen in the well bore from pumping.

Large positive saturation indices for the iron mineral ferrihydrite occurred in water samples collected from observation wells in the northern part of the study area at observation wells CRM-SD-2B (site 938), CRM-SD-11B (site 947), CRM-SD-17 (site 952), CRM-8 (site 991), in the Seminole Well Field at observation well CRM-SD-21 A (site 956), municipal wells Seminole 1 (site 31), 14 (site 44), and 16 (site 46), and in the East Well Field at municipal well East 10 (site 9). Results of geochemical modeling indicate a high potential for ferrihydrite to precipitate from ground water near these wells.

Ground-water samples collected at the intensive study sites were evaluated by geochemical modeling to determine temporal trends in saturation indices. Figures 26 and 27 show selected from saturation indices for water samples from municipal wells Seminole 10 (site 40) and Seminole 1 (site 31). Larger saturation indices for ferrihydrite occurred in water samples collected from municipal well Seminole 1 (site 31) than in 
water samples collected from municipal well Seminole 10 (site 40). Saturation indices for manganite (manganese mineral) also were slightly larger in samples from municipal well Seminole 1 (site 31) than in samples from municipal well Seminole 10 (site 40). Differences in saturation indices for these iron and manganese minerals between municipal wells Seminole 1 and Seminole 10 are consistent with the well-screen plugging problems that have been observed at municipal well Seminole 1 (site 31) (Bob Glass, Cedar Rapids Water Department, written commun., 1993).

Mineral equilibrium conditions in the Devonian aquifer are more stable through time than in the Cedar River alluvial aquifer. The saturation indices calculated by geochemical modeling of ground-water samples collected from the Devonian aquifer (well CRM-6, site 986) were more constant through time when compared to saturation indices calculated for ground water from the Cedar River alluvial aquifer (well CRM-3, site 918). However, the influx of meteoric water from the record rainfall and flooding during the summer of 1993 could have lowered the saturation indices for ground water in the Cedar River alluvial aquifer collected at wells CRM-3 (site 918) and Seminole 10 (site 40) during this time period.

\section{Iron and Manganese Reactions}

The presence of iron and manganese in ground water has an effect on the chemical and microbiological aspects of an aquifer. The reduced forms of iron (Fe II) and manganese (Mn II) are more soluble in water and more mobile than more oxidized forms (Champ and others, 1979; Hem, 1985) and, under anaerobic conditions, are in a favored redox state (Stumm and Morgan, 1970). Microorganisms and organic material are often crucial in catalyzing iron and manganese reduction and oxidation reactions (Chapelle, 1993; Bourg and Bertin, 1994). Lovley (1987) has compiled a list of 36 microorganisms that reduce iron. Reduction proceeds through the following oxidized species in a sequence from left to right: $\mathrm{O}_{2}$, $\mathrm{NO}_{3}{ }^{-}, \mathrm{Mn}$ (IV), $\mathrm{Fe}$ (III), $\mathrm{SO}_{4}{ }^{-2}, \mathrm{HCO}_{3}{ }^{-}$, and $\mathrm{N}_{2}$ (Champ and others, 1979) and is catalyzed by microorganisms. The reduction of $\mathrm{Fe}$ (III) to $\mathrm{Fe}$ (II) and $\mathrm{Mn}$ (IV) to $\mathrm{Mn}$ (II) from aquifer grain coatings can cause large concentrations of these ions in ground water (Lovley and others, 1991; Chapelle, 1993; Bourg and Bertin, 1994). In addition, the reverse reaction can occur where oxida- tion of iron and manganese from the reduced (Fe II and $\mathrm{Mn}$ II) to the more oxidized (Fe III and Mn IV) forms results when ground water enters the well bore, where reduction-oxidation conditions are different from those in the aquifer, causing precipitation of iron and manganese minerals on the well screen (Chapelle, 1993).

The predominance of large iron and manganese concentrations in aquifers can be related to the original depositional environment. Fe (III) oxyhydroxides are produced by weathering reactions and are transported as clay coatings on detrital sediment in fluvial systems. The original depositional environment controls the shape, sorting, and type of materials present in the Cedar River alluvial aquifer. Flood-plain deposits such as sloughs, oxbow lakes, and abandoned channels are commonly comprised of silty mud and organic materia] (Allen, 1965; Smith and Smith, 1980). Levees associated with abandoned channels often contain abundant argillaceous material and can have 10 to 22 percent of their volume as root material (Smith and Smith, 1980). Bourg and Bertin (1994) attributed large concentrations of manganese in wells completed in alluvium near abandoned channel deposits to abundant organic material. The greater percentage of clay in deposits near abandoned channels compared to alluvial sand and gravel also can cause a decrease in the groundwater flow rate and result in faster oxygen depletion. Reducing conditions occur because the rate of oxygen depletion in the ground water is greater than the rate that oxygen is replenished by downward percolation of water from the shallow subsurface zone (Bourg and Bertin, 1994).

Water-quality analyses in ground-water samples from the November 1993 synoptic sampling identified nine wells with large iron and manganese concentrations that might be related to the original depositional environment of the sediment: observation wells CRM-SD-2B (site 938), CRM-SD-11B (site 947), CRM-SD-17 (site 952), CRM-SD-21A (site 956), CRM-8 (site 991); municipal wells Seminole 1 (site 31), 14 (site 44), and 16 (site 46); and municipal well East 10 (site 9). These wells are located near old meander channels or sloughs that contain abundant organic and argillaceous material. Large concentrations of organic matter, degradable by microorganisms, can create reducing conditions in the Cedar River alluvial aquifer and produce large iron and manganese concentrations.

Iron and manganese concentrations in ground water were consistently larger at municipal well Semi- 


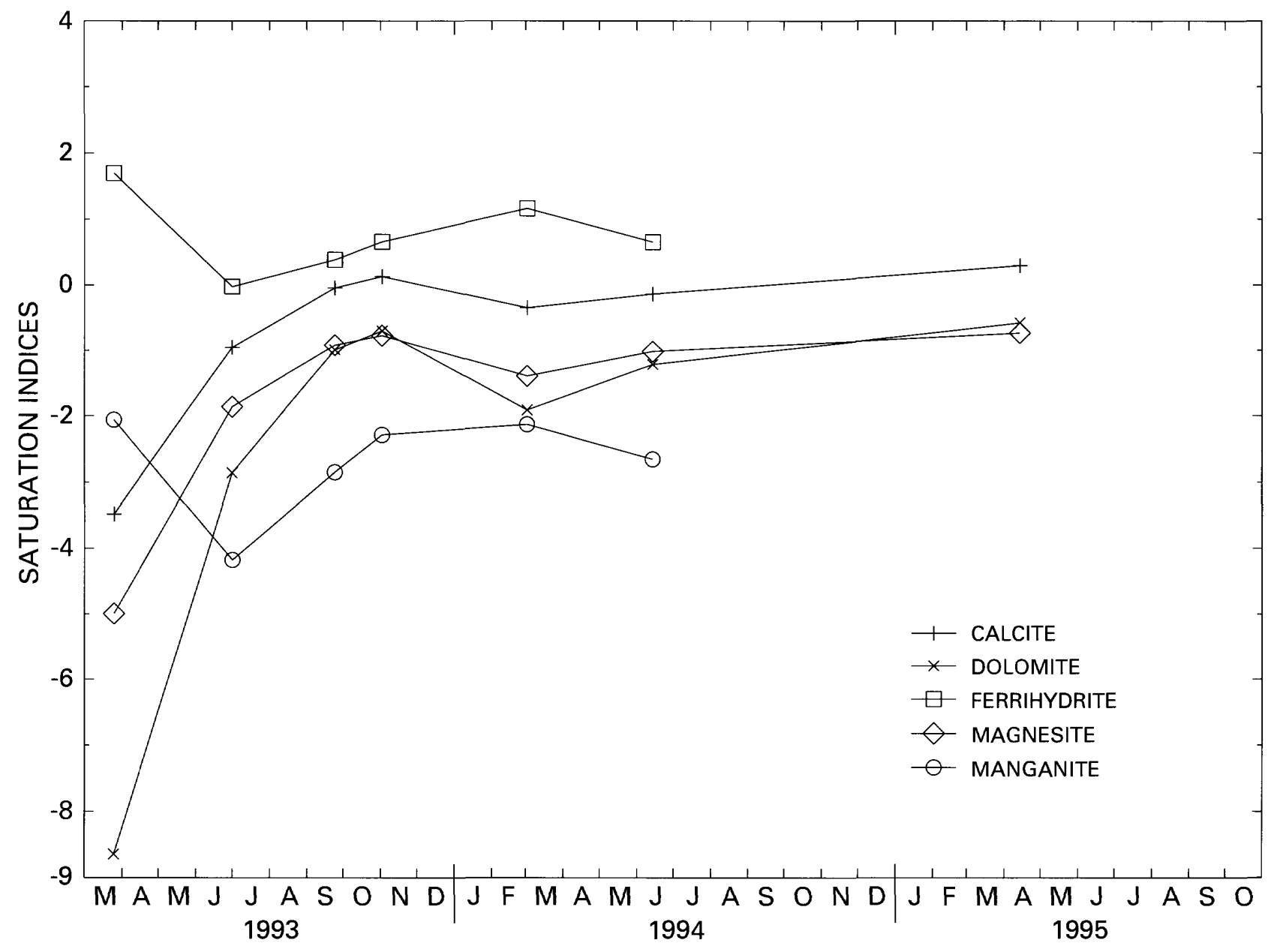

Figure 26. Saturation indices for common minerals in water samples collected from Cedar Rapids municipal well Seminole 10, Cedar Rapids, lowa.

nole 1 (site 31 ) than at municipal well Seminole 10 (site 40), and the differences in iron and manganese concentrations probably are related to the original depositional environment of the sediment. Iron concentrations in ground water typically ranged from 480 to $630 \mu \mathrm{g} / \mathrm{L}$ at municipal well Seminole 1 (site 31 ) and from less than 3 to $23 \mu \mathrm{g} / \mathrm{L}$ at municipal well Seminole 10 (site 40) (Schnoebelen and Schulmeyer, 1996). Manganese concentrations ranged from 760 to $840 \mu \mathrm{g} / \mathrm{L}$ at municipal well Seminole 1 (site 31 ) and from 3 to $170 \mu \mathrm{g} / \mathrm{L}$ at municipal well Seminole 10 (site 40). These wells are similar in construction and in distance from the Cedar River. However, drill cuttings from the observation wells installed near municipal well Seminole 1 (site 31) had a higher percentage of organic-rich material than drill cuttings from observation wells installed near municipal well Seminole 10 (site 40) (Schnoebelen and Schulmeyer, 1996). Sam- ples of screen-encrustation material were analyzed from municipal well Seminole 1 (site 31). One sample was comprised of poorly crystalline (amorphous) forms of iron, and a second sample was comprised mostly of hematite $\left(\mathrm{Fe}_{2} \mathrm{O}_{3}\right)$ (John Neil, USGS, written commun., 1994). These sample analyses are consistent with the positive saturation indices computed for the ground-water samples collected from municipal well Seminole 1 (site 31) (table 10).

Ground water with large iron and manganese concentrations can cause screen-encrustation (catalyzed by microorganisms) upon entering the well bore (Macalady and others, 1990). The well bore contains ideal growth conditions for "iron bacteria" because both anaerobic and aerobic environments are available (Chapelle, 1993). Biofouling in wells, particularly by iron precipitation, can occur when water with $\mathrm{Fe}$ (II) in solution is exposed to more oxygenated water in the 


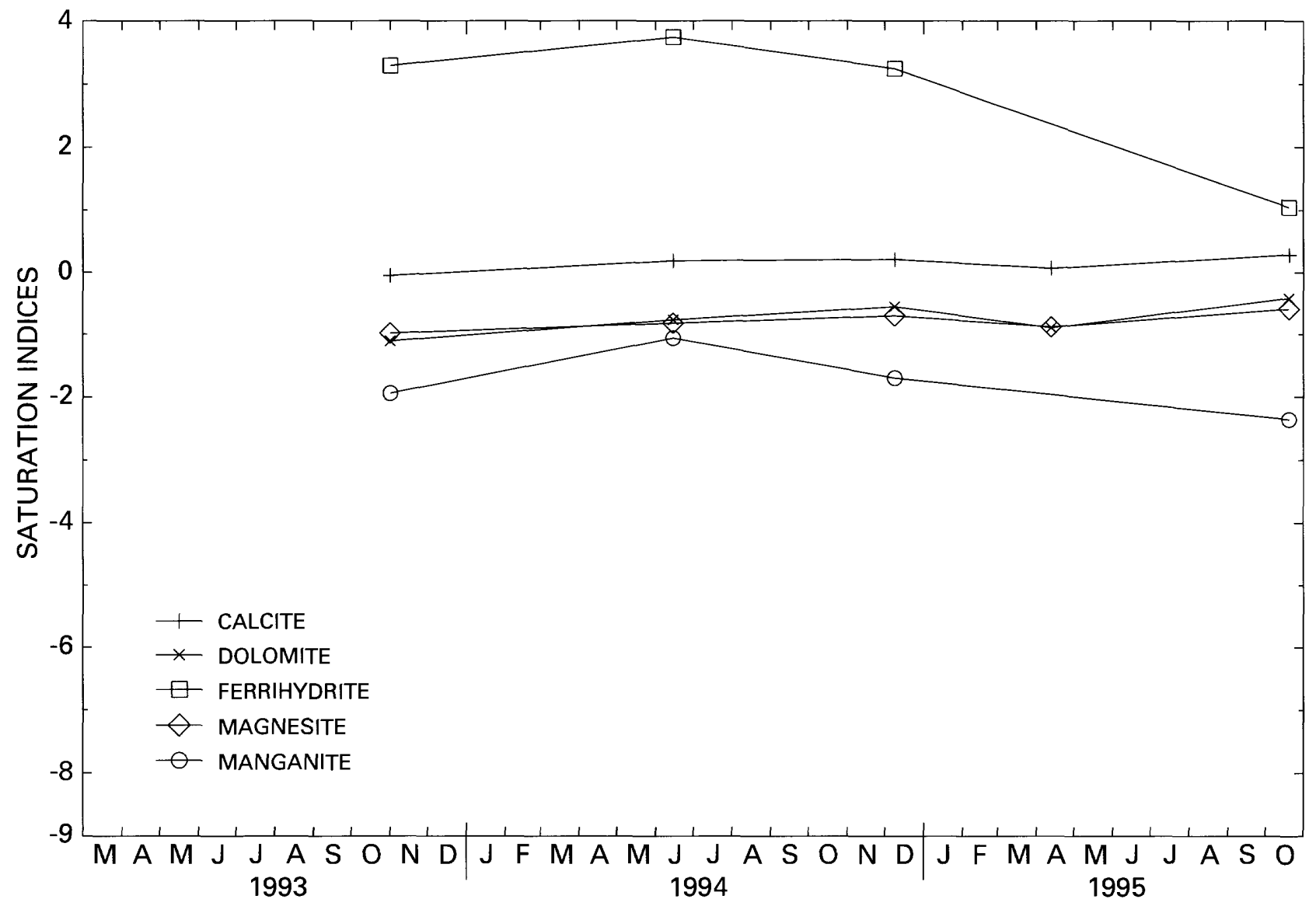

Figure 27. Saturation indices for common minerals in water samples collected from Cedar Rapids municipal well Seminole 1, Cedar Rapids, lowa.

well bore or when water with $\mathrm{Fe}$ (II) in solution is oxidized by aerobic microorganisms and molecular oxygen by the reaction:

$$
4 \mathrm{Fe}^{2+}+\mathrm{O}_{2}+4 \mathrm{H}^{+}=4 \mathrm{Fe}^{+3}+2 \mathrm{H}_{2} \mathrm{O}
$$

Subsequent hydrolysis then produces poorly crystalline forms of $\mathrm{Fe}$ (III) oxides that are relatively insoluble (Macalady and others, 1990). The formation of poorly crystalline forms of $\mathrm{Fe}$ (III), such as ferrihydrite $\left(\mathrm{Fe}_{5} \mathrm{HO}_{8} \cdot 4 \mathrm{H}_{2} \mathrm{O}\right)$, is an initial stage leading to biofouling problems (Carlson and Schwertmann, 1987; Tuhela and others, 1992). In the presence of microorganisms, a simple reaction of $\mathrm{Fe}$ (III) to ferrihydrite may be:

$$
5 \mathrm{Fe}^{3+}+12 \mathrm{H}_{2} \mathrm{O}=\mathrm{Fe}_{5} \mathrm{HO}_{8} \cdot 4 \mathrm{H}_{2} \mathrm{O}+15 \mathrm{H}^{+} .
$$

Other reactions of $\mathrm{Fe}(\mathrm{III})$ to poorly crystalline forms of iron also are possible.

In general, large iron and manganese concentrations in ground water often will be associated with abundant organic and argillaceous material in the sediment, and biofouling due to iron precipitation in water-supply wells can result. Biofouling is one of the most common problems in water-supply well maintenance and in pump-and-treat systems (Chapelle, 1993). Biofouling can lead to corrosive conditions on surfaces of immersed metal structures. Extensive biofouling can clog well screens, pumps, and downstream pipes and filters. When a well is drilled into an aquifer, an anaerobic-aerobic interface is automatically created, and iron encrustation can occur. In areas where ground water has large iron and manganese concentrations, a periodic program of chlorination or other antibacterial measures is needed to keep the well screens and pipes clear of bacteria (Chapelle, 1993). 


\section{Isotopic Analyses}

\section{Oxygen and Hydrogen Isotopes}

Ratios of the primary isotopes that constitute the water molecule, ${ }^{18} \mathrm{O} /{ }^{16} \mathrm{O}$ and ${ }^{2} \mathrm{H} /{ }^{1} \mathrm{H}$, can be useful for understanding the geochemical history of groundwater recharge. Isotope ratios are expressed in delta units $(\delta)$ as per mil (parts per thousand or $0 / 00$ ) differences relative to a standard known as SMOW (Standard Mean Ocean Water). The concentrations of the oxygen isotope $\left(\delta^{18} \mathrm{O}\right)$ and the hydrogen (deuterium) isotope $\left(\delta^{2} \mathrm{H}\right)$ are determined by the isotopic composition of precipitation and the amount of evaporation that occurs before water infiltrates into the soil. Once in the ground-water system, $\delta^{18} \mathrm{O}$ and $\delta^{2} \mathrm{H}$ are part of the water mass, and the isotopes appear to be nonreactive and generally conservative, except in deep or geothermal ground-water systems with temperatures greater than $50-100^{\circ} \mathrm{C}$ (Fritz and others, 1976). The distribution of $\delta^{18} \mathrm{O}$ and $\delta^{2} \mathrm{H}$ in modern precipitation shows excellent correlation with both mean annual air temperature and latitude because of isotopic fractionation (Dansgaard, 1964). The observed global relation between mean $\delta^{18} \mathrm{O}$ isotope concentrations and temperature can actually be described reasonably well by a Rayleigh-distillation type formula given as:

$$
\delta^{2} \mathrm{H}=8 \delta^{18} \mathrm{O}+d(0 / 00),
$$

where $\quad d$ is the deuterium excess (Dansgaard, 1964). Craig (1961) has shown that $d$ approximates the value 10 for meteoric water (modern precipitation) on the global scale and defines an average meteoric waterline (MWL) given as:

$$
\delta^{2} \mathrm{H}=8 \delta^{18} \mathrm{O}+10
$$

to which the isotopic content of ground water can be compared. If past ground-water recharge occurred under climatic conditions similar to those of today, the isotopic composition of the ground water should be similar to that of modern recharge and would plot on the MWL. However, if the ground water was from precipitation at temperatures colder than today (for example, during Pleistocene glaciation), the isotopic composition would be lighter (more negative $\delta$ values) than modern recharge but would still plot near the MWL. The reader is referred to Schotterer and others
(1979), Muir and Coplen (1981), Siegel (1989), and Pearson and others (1991) as examples of the many studies using $\delta^{18} \mathrm{O}$ and $\delta^{2} \mathrm{H}$ isotopes to distinguish between different ground-water types.

Water samples for $\delta^{18} \mathrm{O}$ and $\delta^{2} \mathrm{H}$ isotope analysis were collected during April 1995 from observation wells CRM-1 (site 916), CRM-3 (site 918), CRM-4 (site 919), CRM-6 (site 986), CRM-7 (site 990), CRM-9 (site 992), CRM-10 (site 993), CRM-11 (site 994), CRM-12 (site 995); municipal wells Seminole 2 (site 32), Seminole 10 (site 40); the industrial well at the Pepsi-Cola Plant (site 328); the municipal water works (site 800); and the Cedar River at the Edgewood Bridge site (site 702). The isotopic composition of ground water from the Devonian aquifer and the Cedar River alluvial aquifer are similar to the isotopic composition of modern precipitation. Results for $\delta^{18} \mathrm{O}$ and $\delta^{2} \mathrm{H}$ isotope analysis for this study plot on or very near the MWL (fig. 28) and are similar to isotope data for Chicago precipitation in the late fall to spring recharge period-mean $\delta^{18} \mathrm{O}$ of -8.98 and mean $\delta^{2} \mathrm{H}$ of -62.4 (Daniels and others, 1991).

The $\delta^{18} \mathrm{O}$ and $\delta^{2} \mathrm{H}$ data indicate that the Devonian aquifer in the study area is not completely "isolated" from the ground water in the overlying Cedar River alluvial aquifer and implies that contamination of the Cedar River alluvial aquifer also can affect the underlying bedrock aquifer. No large differences in isotopic composition occurred between any of the aquifer zones that would suggest the presence of ground-water recharge from the Pleistocene age.

\section{Tritium}

Tritium $\left({ }^{3} \mathrm{H}\right)$ is a radioactive isotope that has a half-life of about 12.3 years. The isotope is produced naturally in small amounts in the outer atmosphere; however, large amounts of tritium were introduced into the atmosphere by above-ground thermonuclear tests during the late 1950s and early 1960s. Tritium has been used extensively in hydrogeology as a natural tracer to determine recharge rates and to distinguish different age zones within ground-water flow systems (Freeze and Cherry, 1979).

Prior to initiation of atmospheric thermonuclear testing in 1952, the natural tritium content of precipitation ranged from about 2 to 20 tritium units (Payne, 1972). A tritium unit (TU) is the equivalent of 1 tritium atom in $10^{18}$ atoms of hydrogen or $3.24 \mathrm{pCi} / \mathrm{L}$ as estimated by Thatcher (1962). The first major source of tritium entered the atmosphere during initial testing 


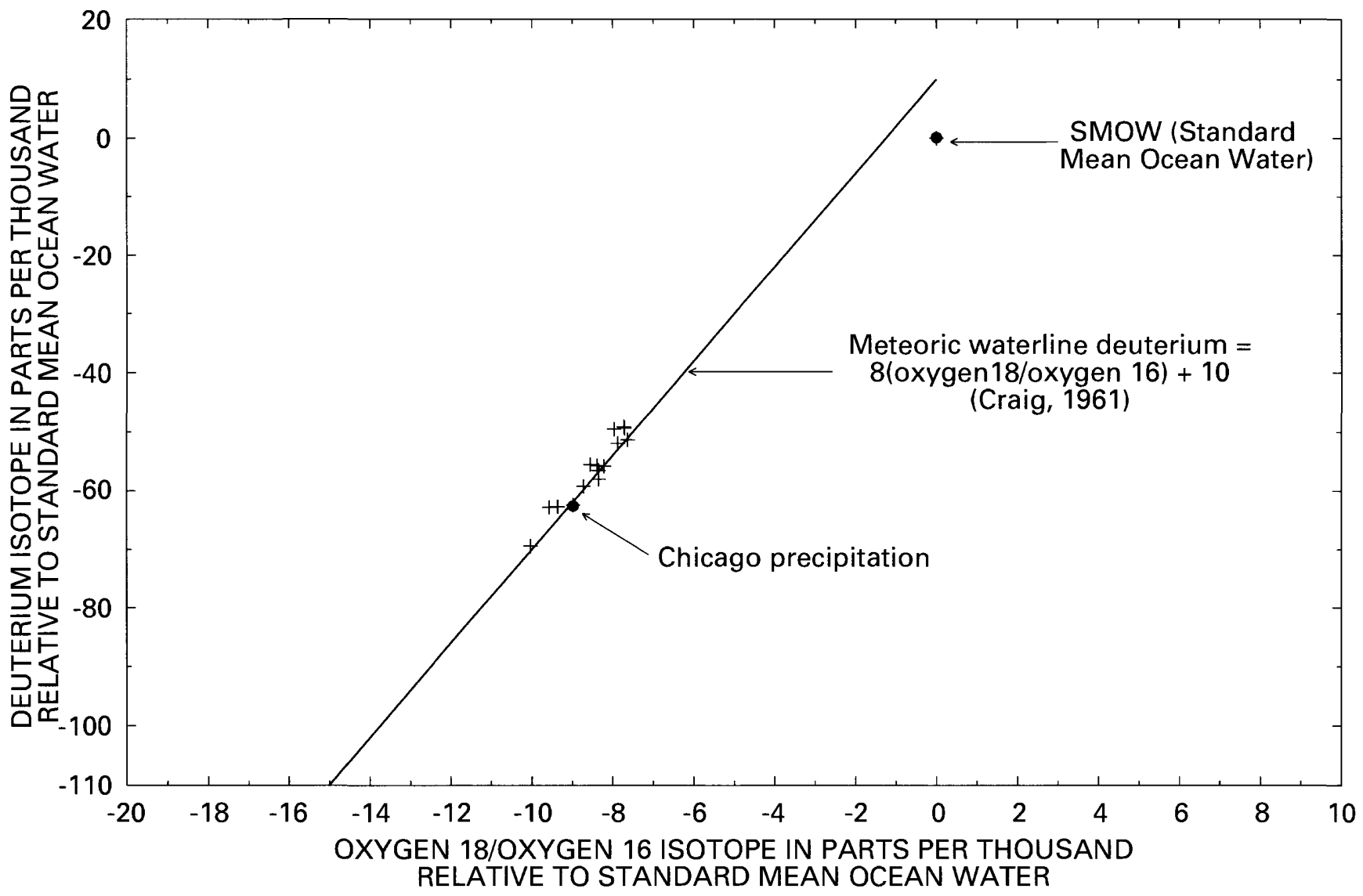

Figure 28. Results of oxygen and deuterium isotope analysis for selected sample sites near Cedar Rapids, lowa, April 1995.

of thermonuclear devices in 1952. More tritium entered the atmosphere during tests in 1954, 1958, 1961, and 1962 (Freeze and Cherry, 1979, p. 136). Because the half-life of tritium is 12.3 years, ground-water recharge prior to 1953 (pre-thermonuclear-test tritium water) typically has tritium concentrations less than $2.0 \mathrm{TU}$ in 1994 (Freeze and Cherry, 1979). Ground water with tritium concentrations greater than $2.0 \mathrm{TU}$ in 1994 indicates post-1953 water (modern water or postthermonuclear-test tritium water). If water contains no detectable tritium, it is reasonable to conclude that post-1953 water is not present.

Water samples were collected for tritium analysis in April 1995 at selected wells in the Cedar River alluvial, Devonian, and Silurian aquifers to determine the presence of younger or older water (table 11). Tritium concentrations greater than $10.0 \mathrm{TU}$ were detected in ground-water samples collected from six wells in the Cedar River alluvial aquifer and two wells in the Devonian aquifer. The large tritium concentrations in water collected from the Cedar River alluvial aquifer at municipal wells Seminole 2 (site 32) and Seminole 10 (site 40) and at observation wells CRM-1 (site 916), CRM-4 (site 919), CRM-9 (site 992), and CRM-10 (site 993) indicate that some of the ground water entered the aquifer sometime after 1953. The large tritium concentrations in water collected from the Devonian aquifer at observation wells CRM-7 (site 990) and CRM-12 (site 995) indicate local downward movement of younger water into the Devonian aquifer.

Water samples collected from the Devonian aquifer at observation wells CRM-6 (site 986) and CRM-11 (site 994) had tritium concentrations less than 1.0 TU and indicate pre-1953 water. The older ground water near these wells indicates areas where there is upward flow from the Devonian aquifer to the Cedar River alluvial aquifer or an area with little hydraulic connection between the Devonian aquifer and the overlying Cedar River alluvial aquifer.

The ground-water sample collected from the Devonian and Silurian aquifers at the Pepsi-Cola Plant (well 328) had a tritium concentration of 9.58 TU. The Pepsi-Cola Plant has an industrial well with a large pumping capacity that may be completed in a part of 
Table 11. Tritium values for water samples collected during April 1995

[ft, feet; pCi/L, picocuries per liter; TU, tritium umit; alluvial aquifer, Cedar River alluvial aquifer]

\begin{tabular}{cllccc}
\hline $\begin{array}{c}\text { Site } \\
\text { number } \\
\text { (figs. 3-5) }\end{array}$ & Site name & Hydrogeologic unit & $\begin{array}{c}\text { Total depth } \\
\text { drilled } \\
\text { (ft) }\end{array}$ & $\begin{array}{c}\text { Tritium } \\
\text { concentration } \\
\text { (pCi/L) }\end{array}$ & $\begin{array}{c}\text { Tritium units } \\
\text { (TU) }\end{array}$ \\
\hline 32 & Seminole 2 & Alluvial aquifer & 63.9 & 37.0 & 11.42 \\
40 & Seminole 10 & Alluvial aquifer & 68.6 & 37.0 & 11.42 \\
916 & CRM-1 & Alluvial aquifer & 39.0 & 41.0 & 12.65 \\
919 & CRM-4 & Alluvial aquifer & 42.5 & 39.0 & 12.04 \\
986 & CRM-6 & Devonian aquifer & 94.0 & 2.0 & .62 \\
990 & CRM-7 & Devonian aquifer & 84.0 & 36.0 & 11.11 \\
992 & CRM-9 & Alluvial aquifer & 74.0 & 37.0 & 11.42 \\
993 & CRM-10 & Alluvial aquifer & 38.0 & 37.0 & 11.42 \\
994 & CRM-11 & Devonian aquifer & 85.0 & 1.9 & .59 \\
995 & CRM-12 & Devonian aquifer & 75.0 & 42.0 & 12.96 \\
& & & Industrial well & & \\
328 & Pepsi-Cola Plant & Devonian and & 480.0 & 31.0 & 9.58 \\
\hline
\end{tabular}

the Devonian and Silurian aquifers that is highly fractured, which allows downward movement of younger ground water in response to pumping. Another possibility for downward movement of younger water at this location might be leakage along the well casing.

\section{IMPLICATION OF WATER-QUALITY AND GROUND-WATER FLOW MODEL RESULTS}

Ground-water flow model results for the $231-\mathrm{mi}^{2}$ model area indicate that most of the recharge to the ground-water flow system is infiltration of precipitation. Simulated inflow from the regional ground-water flow system across the head-dependent boundaries of the model area was minimal at 1.8 percent of total inflow (table 5). Isotopic analysis of water collected from selected wells for oxygen $\left(\delta^{18} \mathrm{O}\right)$ and hydrogen $\left(\delta^{2} \mathrm{H}\right.$ or deuterium) indicates that ground water in the Cedar River alluvial aquifer and the Devonian aquifer is similar to the isotopic composition of modern precipitation. Small differences in the isotopic compo- sition between the aquifers indicate that little or no recharge from older glacial meltwaters has occurred. The $\delta^{18} \mathrm{O}$ and $\delta^{2} \mathrm{H}$ data indicate that the age of ground water in the Devonian aquifer in the detailed study area is similar to the age of ground water in the Cedar River alluvial aquifer.

Upward movement of ground water from the Devonian aquifer to the Cedar River alluvial aquifer in some areas is indicated by study results. The ground-water flow model estimates that 14.8 percent of inflow to the Cedar River alluvial aquifer comes from the Devonian aquifer (layer 2) (table 6). Water levels measured in the Devonian aquifer (table 3) indicate upward ground-water flow near observation wells CRM-6 (site 986) and CRM-11 (site 994). Tritium concentrations in ground-water samples from these two wells in the Devonian aquifer indicate the presence of older, pre-thermonuclear-test water. However, the large amounts of post-thermonuclear-test water in the Cedar River alluvial aquifer would tend to "mask" the signature of smaller amounts of pre-test water that may be moving upward from the Devonian aquifer into the Cedar River alluvial aquifer. 
Hydraulic connection and downward movement of ground water between the Cedar River alluvial, Devonian, and Silurian aquifers in some areas are indicated. Younger post-thermonuclear-test water, determined by tritium analysis, was collected from the Devonian aquifer at observation well CRM-12 (site 995), located near municipal well East 10 (site 9), and from the Devonian aquifer at observation well CRM-7 (site 990), located near municipal well Seminole 1 (site 31). This could indicate an area in which the Devonian aquifer is weathered and in hydraulic connection with the Cedar River alluvial aquifer. The large tritium concentration in water collected from the Devonian and Silurian aquifers at the Pepsi-Cola Plant (table 11) could indicate that the Devonian and Silurian aquifers under the city of Cedar Rapids is being recharged by modern water as infiltration from precipitation or the Cedar River. The model-simulated rate of ground-water flow from layer 1 to layer 2 was $2,904,800 \mathrm{ft}^{3} / \mathrm{d}$ (fig. 18) with no pumping. With pumping simulated in the model, the rate of ground-water flow from layer 1 to layer 2 was calculated at $3,353,690 \mathrm{ft}^{3} / \mathrm{d}$ (fig. 19).

Herbicide concentrations in the Cedar River alluvial aquifer do not directly correlate with concentrations detected in the Cedar River, even though much of the inflow to the Cedar River alluvial aquifer is induced recharge from the Cedar River. Atrazine concentrations in surface-water samples collected from the Cedar River tended to be larger than in ground-water samples collected concurrently from the Cedar River alluvial aquifer. The smaller atrazine concentrations in the Cedar River alluvial aquifer compared to those in the Cedar River may support the ground-water flow model estimates that only a portion of inflow (74.2 percent, table 6) to the Cedar River alluvial aquifer is from river leakage and a portion ( 25.8 percent) comes from other sources, including infiltration of precipitation and leakage from adjacent aquifers. The inflows from other sources may dilute atrazine concentrations of river water in the alluvial aquifer. Adsorption and degradation of these compounds are an alternative explanation for the decrease in concentration of atrazine and other herbicides in the alluvial aquifer compared to those in the Cedar River.

\section{SUMMARY}

A $231-\mathrm{mi}^{2}$ area in Benton and Linn Counties near Cedar Rapids, Iowa, was studied from 1992 through
1996 to evaluate hydrogeology and temporal and spatial variations of selected water-quality characteristics and constituents of the Cedar River, Cedar River alluvial aquifer, Devonian aquifer, and Silurian aquifer. The Cedar River alluvial aquifer is the primary source of drinking water for the city of Cedar Rapids, Iowa.

Hydrogeologic units in the model area include the Cedar River alluvial aquifer, stream alluvial aquifers, loess and eolian sand aquifers, glacial till aquifer, buried-channel aquifer, Devonian aquifer and the local confining unit comprised of limestone, dolomite, and shale of the Otis and Bertram Formations, Silurian aquifer, and the regional confining unit comprised of shale, limestone, and dolomite of the Maquoketa Formation.

A modular, three-dimensional, finite-difference ground-water flow model developed by the USGS (MODFLOW) was used to simulate the ground-water flow system in the model area. The model used a grid of 184 rows by 140 columns with individual cell dimensions of $500 \mathrm{ft}$ by $500 \mathrm{ft}$. The three layers of the steady-state model represented the major hydrogeologic units in the model area. Layer 1 represented unconsolidated deposits and included the Cedar River alluvial aquifer. Layer 2 represented the Devonian aquifer, the weathered portion of the local confining unit (Bertram and Otis Formations), and the buried-channel aquifer. Layer 3 represented the Silurian aquifer.

Model calibration was performed by comparing water levels measured during December 1994 in 30 wells to simulated water levels and by comparing calculated base-flow discharge for streams of similar hydrologic setting within a 50-mi radius of the model area to simulated ground-water discharge to drains for selected subbasins. The RMSE between measured and simulated ground-water levels was $4.5 \mathrm{ft}$, and the AVEH was $0.01 \mathrm{ft}$ for all layers. The calculated base-flow discharge per square mile of drainage basin for streams of similar hydrologic setting ranged from 0.38 to $0.47\left(\mathrm{ft}^{3} / \mathrm{s}\right) / \mathrm{mi}^{2}$, and simulated ground-water discharge for selected subbasins ranged from 0.16 to $0.57\left(\mathrm{ft}^{3} / \mathrm{s}\right) / \mathrm{mi}^{2}$. The calculated base-flow discharge (table 2) in Prairie Creek at Fairfax and the Cedar River at Cedar Rapids measured 0.43 and $0.35\left(\mathrm{ft}^{3} / \mathrm{s}\right) / \mathrm{mi}^{2}$, respectively, and the model simulated ground-water discharge (table 4) of 0.38 and $0.35\left(\mathrm{ft}^{3} / \mathrm{s}\right) / \mathrm{mi}^{2}$, respectively.

Primary sources of inflow to the model are precipitation (63.5 percent), river leakage ( 34.7 percent), and 
flow across the head-dependent boundaries (1.8 percent) (table 5). Infiltration of precipitation occurs primarily through the unconsolidated material, whereas river leakage is an important source of recharge to the Cedar River alluvial aquifer in areas where most pumping occurs. Primary sources of outflow from the model are pumpage (48.3 percent), drain leakage (42.2 percent), and river leakage ( 8.3 percent).

Sources of inflow to and outflow from the Cedar River alluvial aquifer during pumping were determined by conducting a quantitative water-budget analysis.

The primary sources of inflow to the Cedar River alluvial aquifer (table 6) are from river leakage, $5,271,200 \mathrm{ft}^{3} / \mathrm{d}$ (74.2 percent), and vertical leakage from layer $2,1,050,000 \mathrm{ft}^{3} / \mathrm{d}$ (14.8 percent). Infiltration of precipitation accounts for less than 4.9 percent of total inflow $\left(347,300 \mathrm{ft}^{3} / \mathrm{d}\right)$ to the Cedar River alluvial aquifer. Pumpage from the Cedar River alluvial aquifer accounts for 78.0 percent of outflow $\left(5,533,600 \mathrm{ft}^{3} / \mathrm{d}\right)$. River leakage accounts for 13.7 percent of outflow $\left(4,295,700 \mathrm{ft}^{3} / \mathrm{d}\right)$ and indicates that the Cedar River receives ground-water discharge in areas distant from the municipal well fields.

Two simulations of hypothetical conditions using the steady-state, ground-water flow model were conducted to evaluate quantitative changes in sources of water to the Cedar River alluvial aquifer compared to December 1994 hydrologic conditions. Model recharge parameters were decreased by 50 percent, and the stage of the river was lowered by $3 \mathrm{ft}$ to simulate a period of less-than-average annual precipitation for 1961-90. Results for the less-than-average annual precipitation for 1961-90 scenario indicate a 32.0-percent reduction of total volume of ground-water flow in the Cedar River alluvial aquifer and a 5.7-percent increase in river leakage compared to the calibrated model results. Drain leakage decreased by 61.0 percent, and leakage to the river decreased 25.4 percent.

The second scenario simulated a hypothetical increase in pumping from the Cedar River alluvial aquifer. Pumping was increased by 68.3 percent from $5,533,600 \mathrm{ft}^{3} / \mathrm{d}$ (about $41 \mathrm{Mgal} / \mathrm{d}$ ) in the calibrated model to $9,313,900 \mathrm{ft}^{3} / \mathrm{d}$ (about $70 \mathrm{Mgal} / \mathrm{d}$ ). The simulated inflow from river leakage to the Cedar River alluvial aquifer increased 70.8 percent from

$5,271,200 \mathrm{ft}^{3} / \mathrm{d}$ in the calibrated model to $9,007,000 \mathrm{ft}^{3} / \mathrm{d}$ for this scenario.

Surface- and ground-water samples were collected in a one-time sampling survey (synoptic sampling) during November 1993 from 64 municipal, observation, domestic, and industrial wells; and the Cedar River at Edgewood Road Bridge. Commonly used herbicides in Iowa such as atrazine (and the metabolite products deethylatrazine and deisopropylatrazine), cyanazine, and metolachlor, when detected in the Cedar River alluvial aquifer, were typically detected at small concentrations in wells (less than $1.0 \mu \mathrm{g} / \mathrm{L}$ ). Atrazine was detected in 38 of the 64 wells sampled. Most ground-water samples collected from the Devonian and Silurian aquifers had herbicide concentrations less than $0.05 \mu \mathrm{g} / \mathrm{L}$. Nitrite plus nitrate nitrogen (nitrate) concentrations in ground-water samples varied from less than the MRL $(0.05 \mathrm{mg} / \mathrm{L})$ to $15.0 \mathrm{mg} / \mathrm{L}$. Nitrate was not detected in samples from 18 wells, and nitrate concentrations in samples from four wells were greater than the MCL for nitrate as nitrogen $(10 \mathrm{mg} / \mathrm{L})$.

Water-quality samples were collected about every 3 to 4 months from four observation wells and two municipal wells completed in the Cedar River alluvial aquifer, two observation wells completed in the Devonian aquifer, and the Cedar River at two intensive study sites in the Seminole Well Field. Herbicide concentrations were generally largest after spring runoff in both the river and ground water. However, the herbicide concentrations in the ground water during the spring and early summer runoff were less than in the Cedar River.

Water-quality analyses for ground-water samples collected during the November 1993 synoptic sampling identified nine wells with large iron and manganese concentrations that may be related to the original depositional environment of the sediment. The wells are located near old meander channels or sloughs that contain abundant organic and argillaceous material. Large concentrations of organic matter, degradable by microorganisms, can create reducing conditions in the Cedar River alluvial aquifer and produce large iron and manganese concentrations. In general, large iron and manganese concentrations in ground water often will be associated with abundant organic and argillaceous material in the sediment. This can result in the biofouling of screens in water-supply wells due to iron precipitation.

Water samples were collected for tritium analysis during April 1995 from selected wells in the Cedar River alluvial, Devonian, and Silurian aquifers. Tritium concentrations greater than 10.0 TU were detected in ground-water samples collected from six wells in the Cedar River alluvial aquifer and two wells in the Devonian aquifer. The large tritium concentra- 
tions in water collected from the alluvial aquifer indicate that the ground water entered the aquifer after 1953. The large tritium concentrations in water collected from the Devonian aquifer at observation wells CRM-7 (site 990) and CRM-12 (site 995) indicate local downward movement of younger water into the Devonian aquifer. Water samples collected from the Devonian aquifer at observation wells CRM-6 (site 986) and CRM-11 (site 994) had tritium concentrations less than 1.0 TU and indicate pre-1953 water. The older ground water from these wells could indicate areas where there is upward flow from the Devonian aquifer. The ground-water sample collected from the Devonian and Silurian aquifers at the Pepsi-Cola Plant (site 328) had a tritium concentration of 9.58 TU. The Pepsi-Cola Plant has an industrial well with a large pumping capacity that may be completed in a part of the Devonian and Silurian aquifers that is highly fractured, which allows downward movement of younger ground water in response to pumping. Another explanation for downward movement of younger water at this location may be leakage along the well casing.

Herbicide concentrations in the Cedar River alluvial aquifer did not directly correlate with concentrations detected in the Cedar River, even though much of the inflow to the Cedar River alluvial aquifer is from induced recharge from the Cedar River. Atrazine concentrations in surface-water samples collected from the Cedar River tended to be larger than in ground-water samples collected concurrently from the Cedar River alluvial aquifer. The smaller atrazine concentrations in the Cedar River alluvial aquifer compared to the Cedar River may support the ground-water flow model estimates that only a portion of inflow (74.2 percent) to the Cedar River alluvial aquifer is from river leakage. The inflows from other sources can dilute atrazine concentrations of river water that enters the alluvial aquifer. Other explanations for the decrease in atrazine concentration and other herbicides in the alluvial aquifer compared to river water might be adsorption and degradation of these compounds.

\section{REFERENCES CITED}

Allen, J.R.L., 1965, A review of the origin and characteristics of recent alluvial sediments: Sedimentology, v. 5, p. 89-191.
Anderson, M.P., and Woessner, W.W., 1992, Applied groundwater modeling-Simulation of flow and advective transport: Academic Press, Inc., 381 p.

Anderson, W.I., 1983, Geology of lowa: Ames, Iowa, The lowa State University Press, 268 p.

Ashtech Company, 1991, GPS field surveying techniques, Ashtech GPS techniques manual: Sunnyvale, California, $11 \mathrm{p}$.

Bourg, A.C., and Bertin, C., 1994, Seasonal and spatial trends in manganese solubility in an alluvial aquifer: Environmental Science and Technology, v. 28, p. 868-876.

Bunker, B.J., Ludvigson, G.A., and Witzke, B.J., 1985, The Plum River fault zone and the structural and stratigraphic framework of eastern Iowa: lowa Geological Survey, Technical Information Series, no. 13, p. 123.

Busby, J.F., Plummer, N., Lee, R.W., and Hanshaw, B.B., 1991, Geochemical evolution of water in the Madison aquifer in parts of Montana, South Dakota, and Wyoming: U.S. Geological Survey Professional Paper 1273-F, 89 p.

Carlson, L., and Schwertmann, U., 1987, Iron and manganese oxides in Finnish ground water treatment plants: Water Research, v. 21, p. 165-170.

Champ, D.R., Gulens, J., and Jackson, R.E., 1979, Oxidation-reduction sequences in ground water flow systems: Canadian Journal of Earth Sciences, v. 16, no. 1, p. 12-23.

Chapelle, F.H., 1993, Ground-water microbiology and geochemistry: New York, John Wiley and Sons, Inc., $424 \mathrm{p}$.

Chapelle, F.H., and Lovley, D.R., 1994, Competitive exclusion of sulfate reduction by $\mathrm{Fe}$ (III)-reducing bacteria-A mechanism for producing discrete zones of high-iron ground water: Ground Water, v. 30. no.1, p. 29-36.

Craig H., 1961, Isotopic variations in meteoric waters: Science, v. 133, p. 1702-1703.

Daniels, D.P., Fritz, S.J., and Leap, D.I., 1991, Estimating recharge rates through unsaturated glacial till by tritium tracing: Ground Water, v. 29, no. 1, p. 26-34.

Dansgaard, W., 1964, Stable isotopes in precipitation: Tellus, v. 16, p. 435-468.

Fetter, C.W., 1994, Applied hydrology (3d ed.): New York, Mcmillan College Publ. Co., 691 p.

Fishmen, M.J., and Friedman, L.C., eds., 1989, Methods for determination of inorganic substances in water and fluvial sediments (3d ed.): U.S. Geological Survey Techniques of Water-Resources Investigations, book 5 , chap. Al, 545 p.

Freeze, R.A., and Cherry, J.A., 1979, Groundwater: Englewood Cliffs, N.J., Prentice Hall, 604 p.

Fritz, P., Cherry, J.A., Weyer, K.U., and Sklash, M., 1976, Storm run-off analysis using environmental isotopes and major ions, in Interpretation of environmental iso- 
tope and hydrochemical data in groundwater hydrology: Proceedings of an advisory group meeting, International Atomic Energy Agency, Vienna, January 1975, p. 111-130.

Haeni, F.P., 1986, Application of continuous seismic reflection methods to hydrologic studies: Ground Water, v. 24 , no. 1 , p. $23-31$.

1988, Application of seismic-refraction techniques to hydrologic studies: U.S. Geological Survey Techniques of Water-Resources Investigations, book 2, chap. D2, 86 p.

Haeni, F.P., and Melvin, R.L., 1984, High resolution continuous seismic reflection study of a stratified drift deposit in Connecticut, in Neilson, D.M., and Curl, M., eds., National Water Well Association-Environmental Protection Agency Conference on Surface and Borehole Geophysical Methods in Ground Water Investigations, San Antonio, Texas, 1984, Proceedings: Worthington, Ohio, National Water Well Association, p. 237-256.

Hallberg, G.R., 1980, Pleistocene stratigraphy in east-central, Iowa: Iowa Geological Survey, p. 168.

1989, Nitrate in ground water in the United States, in Follett, R.F., ed., Nitrogen management and ground water protection-Developments in agricultural and managed-forest ecology: New York, Elsevier, p. 25-74.

Hallberg, G.R., Fenton, T.E., Miller, G.A., and Luteneggar, A.J., 1978, The Iowan erosion surface-An old story, an important lesson, and some new wrinkles, in Anderson, R.R., ed., 42nd Annual Tri-State Geological Field Conference Guidebook, October 13-15, 1978: Iowa City, Iowa Geological Survey, p. 94.

Hansen, R.E., 1970, Geology and ground-water resources of Linn County, Iowa: Iowa Geological Survey, Water-Supply Bulletin No. 10, 66 p.

Hansen, R.E., and Steinhilber, W.L., 1977, Geohydrology of Muscatine Island, Muscatine County, Iowa: Iowa Geological Survey, Water-Supply Bulletin No. 11, 66 p.

Harbaugh, A.W., 1990, A computer program for calculating subregional water budgets using results from the U.S. Geological Survey modular three-dimensional finite-difference ground-water flow model: U.S. Geological Survey Open-File Report 90-392, 46 p. 1994: A data input program (MFI) for the U.S. Geological Survey modular finite-difference ground-water flow model: U.S. Geological Survey Open-File Report 94-468, 24 p.

Heath, R.C., 1987, Basic ground-water hydrology: U.S. Geological Survey Water-Supply Paper 2220, p. 60-61.

Hem, J.D., 1985, Study and interpretation of the chemical characteristics of natural water: U.S. Geological Survey Water-Supply Paper 2254, 263 p.

Hill, M.C., 1990, Preconditioned conjugate-gradient 2 (PCG2)-A computer program for solving groundwater flow equations: U.S. Geological Survey Water-Resources Investigations Report 90-4048, 43 p.
Holden, L.R., Graham, J.A., Whitmore, R.W., Alexander, W.J., Pratt, R.W., Liddle, S.K., and Piper, L.L., 1992, Results of the National Alachlor Well Water Survey: Environmental Science and Technology, v. 26, no. 5, p. 935-943.

Iowa Department of Environmental Quality, 1976, Water quality management plan, Iowa-Cedar River basin: Des Moines, Planning and Analysis Section, Water Quality Management Division, 376 p.

Keller, C.K., van der Kemp, Garth, and Cherry, J.A., 1986, Fracture permeability and ground-water flow in a clayey till near Saskatoon, Saskatchewan: Canadian Geotechnical Journal, v. 23, no. 2, p. 229-240.

Kolpin, D.W., Burkart, M.R., and Thurman, E.M., 1991, Herbicides and nitrate in near-surface aquifers in the midcontinental United States, 1991: U. S. Geological Survey Water-Supply Paper 2413, 34 p.

Kunkle, G.R., 1965, Computation of ground-water discharge to streams during floods, or to individual reaches during base flow, by use of specific conductance in Geological Survey research: U.S. Geological Survey Professional Paper 525-D, p. D207-D210.

1968, A hydrogeologic study of the ground-water reservoirs contributing base runoff to Four Mile Creek, east-central Iowa: U.S. Geological Survey Water-Supply Paper 1839-O, $41 \mathrm{p}$.

Langbein, W.B., and Iseri, K.T., 1960, General introduction and hydrologic definitions, Manual of hydrology, Part 1, General surface-water techniques: U.S. Geological Survey Water-Supply Paper 1545-A, 29 p.

Libra, R.D., and Hallberg, G.R., 1985, Hydrogeologic observations from multiple core holes and piezometers in the Devonian-carbonate aquifers in Floyd and Mitchell Counties, Iowa: Iowa Geological Survey Open-File Report 85-2, p. 1-20.

Lovley, D.R., 1987, Organic matter mineralization with the reduction of ferric iron-A review: Geomicrobiology Journal, v. 5, no. 34, p. 375-399.

Lovley, D.R., Phillips, E.J.P., and Lonergan, D.J., 1991, Enzymatic versus nonenzymatic mechanisms for $\mathrm{Fe}(\mathrm{III})$ reduction in aquatic sediments: Environmental Science and Technology, v. 25, no. 6, p. 1062-1067.

Lucey, K.J., Kuzniar, R.L., and Caldwell, J.P., 1995, Hydrogeology and water quality of the Mississippi River alluvium near Muscatine, Iowa, June 1992 through 1994: U.S. Geological Survey Water-Resources Investigations Report 95-4049, 74 p.

Macalady, D.L., Langmuir, D., Grundl, T., and Elzerman, A., 1990, Use of model-generated $\mathrm{Fe}^{3+}$ ion activities to compute Eh and ferric oxyhydroxide solubilitics in anaerobic systems, in Melchlor, D.C., and Bassett, R.L., eds., Chemical modeling of aqueous systems II: Washington, D.C., American Chemical Society, p. $350-367$. 
May, J.E., Sneck-Fahrer, D., Gorman, J.G., Goodrich, R.D., Nations, B.K., and Miller, V.E., 1994, Water resources data, lowa, water year 1994: U.S. Geological Survey Water-Data Report IA-94-1, 370 p.

McDonald, M.G., and Harbaugh, A.W., 1988, A modular three-dimensional finite-difference ground-water flow model: U.S. Geological Survey Techniques of Water-Resources Investigations, book 6, chap. A1, $586 \mathrm{p}$.

Muir, K.S., and Coplen, T.B., 1981, Tracing ground-water movement by using the stable isotopes of oxygen and hydrogen, Upper Penitencia Creek alluvial fan, Santa Clara Valley, California: U.S. Geological Survey Water-Supply Paper 2075, 18 p.

Neil, M., 1989, Nitrate concentrations in river waters in the south east of Ireland and their relationship with agricultural practice: Water Resources, v. 23, p. 1339-1355.

Nordstrom, D.K., and Ball, J.W., 1989, Mineral saturation states in natural waters and their sensitivity to thermodynamic and analytic errors: Scientific Geology Bulletin, v. 42 , no. 4 , p. 269-280.

O'Connell, D.J., Liszewski, M.J., Lambert, R.B., and Matthes, W.J., 1989, Water resources data, Iowa, water year 1989: U.S. Geological Survey Water-Data Report IA-89-1, $399 \mathrm{p}$.

Owenby, J.R., and Ezell, D.S., 1992, Monthly station normals of temperature, precipitation, and heating and cooling degree days 1961-1990, Iowa: Asheville, N.C., National Climatic Data Center, National Oceanic and Atmospheric Administration, Climatography of the United States no. 81, 32 p.

Parker, M.C., 1971, The Maquoketa formation (Upper Ordovician) in Iowa: lowa Geological Survey, Miscellaneous Map Series 1, 6 sheets, scale 1:1,000,000.

Parrett, Charles, Melcher, N.B., and James, R.W., Jr., 1993, Flood discharges in the upper Mississippi River Basin, 1993: U.S. Geological Survey Circular 1120-A, 14 p.

Payne, B.R., 1972, Isotope hydrology: Advanced Hydrosciences, v. 8, p. 95-138.

Pearson, F.J., Jr., Balderer, W., Loosli, H. H., Lehmann, B.E., Matter, A., Peters, T.J., Schmassmann, H., and Gautschi, A., 1991, Applied isotope hydrology-A case study in northern Switzerland, in Studies in environmental science, 43: Amsterdam, Elsevier Publ., 439 p.

Piper, A.M., 1953, A graphic procedure in the geochemical interpretation of water analyses: U.S. Geological Survey Ground Water Notes, Geochemistry, No. 12, 14 p.

Plummer, N.L., Jones, B.F., and Truesdell, A.H., 1976, WATEQF-A FORTRAN IV version of WATEQ, a computer program for calculating chemical equilibrium of natural water: U.S. Geological Survey WaterResources Investigations 76-13, $70 \mathrm{p}$.

Pollock, D.W., 1989, Documentation of the computer programs to compute and display pathlines using results from the U.S. Geological Survey modular three-dimen- sional finite-difference ground-water flow model: U.S. Geological Survey Open-File Report 89-381, 188 p. -1994, User's guide for MODPATH/MOD-

PATH-PLOT, version 3-A particle tracking post-processing package for MODFLOW, the U.S. Geological Survey finite-difference ground-water flow model: U.S. Geological Survey Open-File Report 94-464, 6 ch.

Rutledge, A.T., 1993, Computer programs for describing the recession of ground-water discharge and for estimating mean ground-water recharge and discharge from streamflow records: U.S. Geological Survey WaterResources Investigations Report 93-4121, 45 p.

Schermerhorn, E.J., and Highland, J.D., 1975, Soil survey of Linn County, Iowa: U.S. Department of Agriculture, Soil Conservation Service, 145 p.

Schneider, R., 1962, An application of thermometry to the study of ground water: U.S. Geological Survey Water-Supply Paper 1544-B, 16 p.

Schnoebelen, D.J., and Schulmeyer, P.M., 1996, Selected hydrogeologic data in the Cedar Rapids area, Benton and Linn Counties, Iowa, October 1992 through March 1996: U.S. Geological Survey Open-File Report 96-471, 172 p.

Schotterer, U., Wildberger, A., Siegenthaler, W., Nabholz, W., and Oeschger, H., 1979, Isotope study in the alpine karst region of Rawil, Switzerland, in Isotope hydrology, 1978, v. 1: Vienna, International Atomic Energy Agency, p. 351-365.

Schulmeyer, P.M., 1991, Relation of selected water-quality constituents to river stage in the Cedar River, lowa, in Mallard, G.E., and Aronson, D.A., eds., U.S. Geological Survey Toxic Substances Hydrology ProgramProceedings of the technical meeting, Monterey, California, March 11-15, 1991: U.S. Geological Survey Water-Resources Investigations Report 91-4034, p. 227-231.

1995, Effect of the Cedar River on the quality of the ground-water supply for Cedar Rapids, Iowa: U.S. Geological Survey Water-Resources Investigations Report 94-4211, 68 p.

Scott, J.H., 1977a, SIPB-A seismic inverse modeling program for batch computer systems: U.S. Geological Survey Open-File Report 77-366, 40 p.

-1977b, SIPT-A seismic refraction inverse modeling program for timeshare terminal computer systems: U.S. Geological Survey Open-File Report 77-365, $35 \mathrm{p}$.

Siegel, D.I., 1989, Geochemistry of the Cambrian-Ordovician aquifer system in the northern Midwest, United States: U.S. Geological Survey Professional Paper 1405-D, 76 p. 
Sloto, R.A., 1991, A computer method for estimating ground-water contribution to streamflow using hydrograph-separation techniques, in Balthrop, B.H., and Terry, J.E., eds., U.S. Geological Survey National Computer Technology Meetings, Phoenix, Arizona, 1988, Proceedings: U.S. Geological Survey Water-Resources Investigations Report 90-4162, p. 101-110.

Smith, D.G., and Smith, N.D., 1980, Sedimentation in anastomosed river systems-Examples from alluvial valleys near Banff, Alberta: Journal of Sedimentary Petrology, v. 50, p. 157-164.

Squillace, P.J. 1996, Observed and simulated movement of bank-storage water: Ground Water, January-February, v. 34 , no. 1 , p. 121-134.

Squillace, P.J., Caldwell, J.P., Schulmeyer, P.M., and Harvey, C.A., 1996, Movement of agricultural chemicals between surface water and ground water, lower Cedar River Basin, Iowa: U.S. Geological Water-Supply Paper 2448, 59 p.

Squillace, P.J., Liszewski, M.J., and Thurman, E.M., 1993, Agricultural chemical interchange between ground water and surface water, Cedar River Basin, Iowa and Minnesota-A study description: U.S. Geological Survey Open-File Report 92-85, p. 26.

Stumm, W., and Morgan, J.J., 1970, Aquatic chemistry (2nd ed.): New York, John Wiley and Sons, 780 p.

Thatcher, L.L., 1962, The distribution of tritium fall out in precipitation over North America: Bulletin of the International Association of Scientific Hydrology, v. 7, no. 2 , p. $48-58$.

Thurman, E.M., Goolsby, D.A., Meyer, M.T., and Kolpin, D.W., 1991, Herbicides in surface water of the Midwestern United States-The effect of spring flush: Environmental Science and Technology, v. 25, no. 10, p. 1794-1796.
Timme, P.J., 1995, National Water Quality Laboratory 1995 services catalog: U.S. Geological Survey Open-File Report 95-352, 120 p.

Todd, D.K., 1980, Groundwater hydrology: New York, John Wiley and Sons, $535 \mathrm{p}$.

Tucci, Patrick, 1992, Hydrology of Melton Valley at Oak Ridge National Laboratory, Tennessee: U.S. Geological Survey Water-Resources Investigations Report 92-4131, 76 p.

Tuhela, L., Carlson, L., and Tuovinen, O.H., 1992, Ferrihydrite in well water samples and bacterial enrichment cultures: Water Research, v. 26, p. 1159-1162.

U.S. Department of Agriculture, 1976, Iowa-Cedar Rivers basin study: Des Moines, Iowa, $250 \mathrm{p}$.

U.S. Environmental Protection Agency, 1984, National Secondary Drinking Water Regulations: U.S. Environmental Protection Agency, Office of Ground Water and Drinking Water, EPA-570/9-76-000, Appendix A. 1986, Quality criteria for water-1986: U.S. Environmental Protection Agency, Office of Ground Water and Drinking Water, EPA-440/5-86-001, 446 p.

U.S. Geological Survey, 1977, National handbook of recommended methods for water-data acquisition: Reston, Virginia, Office of Water Data Coordination, Geological Survey, U.S. Department of the Interior, ch. 2, p. 8-10.

Wahl, K.D., and Bunker, B.J., 1986, Hydrology of carbonate aquifers in southwestern Linn County and adjacent parts of Benton, Iowa, and Johnson Counties, Iowa: Iowa Geological Survey, Water-Supply Bulletin No. 15, $56 \mathrm{p}$.

Wang, W., and Squillace, P., 1994, Herbicide interchange between a stream and the adjacent alluvial aquifer: Environmental Science and Technology, v. 28, p. 2336-2344. 
70 Hydrogeology and Water Quaiity in the Cedar Rapids Area, iowa, 1992-96 


\section{SUPPLEMENTAL INFORMATION}


72 Hydrogeology and Water Quallty In the Cedar Raplds Area, lowa, 1992-96 
Tabie 12. Information for selected wells and surface-water sites near Cedar Rapids, lowa

[Site number, an assigned number that relates data from tables and figures in this report; Land-surface elevation, feet above sea level; Total depth drilled, in feet below land surface; --, no data or not applicable. Additional well data are in Schnoebelen and Schulmeyer (1996)1

\begin{tabular}{|c|c|c|c|c|c|c|}
\hline $\begin{array}{l}\text { Site number } \\
\text { (see figs. } \\
2-5 \text { for } \\
\text { iocation) }\end{array}$ & Site name & $\begin{array}{l}\text { U.S. Geologicai } \\
\text { Survey site identi- } \\
\text { fication number }\end{array}$ & $\begin{array}{l}\text { Land- } \\
\text { surface } \\
\text { eieva- } \\
\text { tion } \\
\text { (feet) }\end{array}$ & $\begin{array}{l}\text { Type of } \\
\text { data } \\
\text { coiiected }^{1}\end{array}$ & $\begin{array}{l}\text { Totai } \\
\text { depth } \\
\text { driiled } \\
\text { (feet) }\end{array}$ & $\begin{array}{l}\text { USGS } \\
\text { aquifer } \\
\text { code }^{2}\end{array}$ \\
\hline \multicolumn{7}{|c|}{ Cedar Rapids municipal wells } \\
\hline 1 & East 1 & 415946091403901 & 720.0 & G, LF93 & 70.0 & 111ALVM \\
\hline 2 & East 2 & 415949091404301 & 720.0 & G, LF93 & 72.0 & 111ALVM \\
\hline 3 & East 3 & 415949091404901 & 720.0 & G, LF93 & 72.0 & $111 \mathrm{ALVM}$ \\
\hline 4 & East 4 & 415954091405101 & 720.0 & G, LF93 & 72.0 & 111ALVM \\
\hline 5 & East 5 & 415954091405601 & 720.0 & G, LF93 & 71.5 & 111ALVM \\
\hline 6 & East 6 & 415944091403501 & 720.0 & G, LF93 & 70.0 & 111ALVM \\
\hline 7 & East 8 & 415941091404101 & 720.0 & G, LF93 & 69.6 & 111ALVM \\
\hline 8 & East 9 & 415944091404801 & 720.0 & G, LF93 & 67.0 & 111ALVM \\
\hline 9 & East 10 & 415949091405201 & 718.4 & $\begin{array}{l}\text { G, LF93, } \\
\text { WQI }\end{array}$ & 67.0 & 111ALVM \\
\hline 10 & East 11 & 415950091405501 & 718.9 & G, LF93 & 57.0 & 111ALVM \\
\hline 11 & East 12 & 415952091405701 & 719.1 & G, LF93 & 61.0 & 111ALVM \\
\hline 12 & East 13 & 415955091410101 & 718.9 & $\begin{array}{c}\text { G, LF93, } \\
\text { WQI }\end{array}$ & 61.0 & 111ALVM \\
\hline 13 & East 14 & 415959091410501 & 720.0 & G, LF93 & 65.0 & 111ALVM \\
\hline 14 & East 15 & 420000091410701 & 719.4 & G, LF93 & 67.0 & 111ALVM \\
\hline 15 & East 16 & 420002091410701 & 720.0 & G, LF93 & 69.0 & 111ALVM \\
\hline 16 & East 17 & 420005091411001 & 719.4 & G, LF93 & 59.8 & 111ALVM \\
\hline 17 & East 18 & 420007091411201 & 720.4 & G, LF93 & 59.8 & 111ALVM \\
\hline 18 & East 19 & 420010091411501 & 720.5 & G, LF93 & 58.0 & $111 \mathrm{ALVM}$ \\
\hline 19 & East 20 & 420013091411601 & 720.6 & G, LF93 & 57.0 & 111ALVM \\
\hline 20 & West 1 & 420012091412801 & 716.0 & G, LF93 & 66.0 & 111ALVM \\
\hline 21 & West 2 & 420017091413401 & 716.0 & G, LF93 & 72.0 & 111ALVM \\
\hline 22 & West 3 & 420024091414601 & 716.0 & G, LF93 & 72.0 & 111ALVM \\
\hline 23 & West 4 & 420029091415501 & 717.0 & G, LF93 & 69.0 & 111ALVM \\
\hline 24 & West 5 & 420034091410501 & 720.0 & G, LF93 & 68.0 & 111ALVM \\
\hline 25 & West 6 & 420037091421401 & 720.0 & G, LF93 & 71.0 & $111 \mathrm{ALVM}$ \\
\hline 26 & West 7 & 420036091422701 & 721.0 & $\begin{array}{l}\text { G, LF93, } \\
\text { WQI }\end{array}$ & 70.0 & 111ALVM \\
\hline 27 & West 8 & 420032091423301 & 721.0 & G, LF93 & 72.0 & 111ALVM \\
\hline 28 & West 9 & 420031091415701 & 714.0 & G, LF93 & 63.0 & 111ALVM \\
\hline 29 & West 10 & 420036091420901 & 715.5 & $\begin{array}{c}\text { G, LF93, } \\
\text { WQI }\end{array}$ & 67.0 & 111ALVM \\
\hline 30 & West 11 & 420039091422101 & 720.5 & G, LF93 & 66.0 & 111ALVM \\
\hline 31 & Seminole 1 & 420030091424901 & 721.1 & $\begin{array}{c}\text { G, LF93, } \\
\text { WQQ }\end{array}$ & 63.9 & 111ALVM \\
\hline
\end{tabular}


Table 12. Information for selected wells and surface-water sites near Cedar Rapids, lowa-Continued

\begin{tabular}{|c|c|c|c|c|c|c|}
\hline $\begin{array}{l}\text { Site number } \\
\text { (see figs. } \\
2-5 \text { for } \\
\text { location) }\end{array}$ & Site name & $\begin{array}{l}\text { U.S. Geological } \\
\text { Survey site identi- } \\
\text { fication number }\end{array}$ & $\begin{array}{l}\text { Land- } \\
\text { surface } \\
\text { eleva- } \\
\text { tion } \\
\text { (feet) }\end{array}$ & $\begin{array}{l}\text { Type of } \\
\text { data } \\
\text { collected }\end{array}$ & $\begin{array}{l}\text { Total } \\
\text { depth } \\
\text { drilled } \\
\text { (feet) }\end{array}$ & $\begin{array}{l}\text { USGS } \\
\text { aquifer } \\
\text { code }^{2}\end{array}$ \\
\hline \multicolumn{7}{|c|}{ Cedar Rapids municipal wells-Continued } \\
\hline 32 & Seminole 2 & 420025091425801 & 720.0 & G, LF93 & 53.9 & 111ALVM \\
\hline 33 & Seminole 3 & 420020091430601 & 719.8 & G, LF93 & 62.9 & 111ALVM \\
\hline 34 & Seminole 4 & 420015091430601 & 720.0 & G, LF93 & 54.9 & 111ALVM \\
\hline 35 & Seminole 5 & 420009091431901 & 720.8 & G, LF93 & 64.0 & 111ALVM \\
\hline 36 & Seminole 6 & 420006091432201 & 722.0 & G, LF93 & 61.1 & 111 ALVM \\
\hline 37 & Seminole 7 & 415959091433001 & 722.4 & G, LF93 & 63.1 & 111ALVM \\
\hline 38 & Seminole 8 & 415955091433601 & 721.4 & $\begin{array}{l}\text { G, LF93, } \\
\text { WQI }\end{array}$ & 57.3 & 111ALVM \\
\hline 39 & Seminole 9 & 415952091434301 & 724.0 & G, LF93 & 57.5 & 111ALVM \\
\hline 40 & Seminole 10 & 415953091435201 & 725.4 & $\begin{array}{l}\text { G, LF93, } \\
\text { WQQ }\end{array}$ & 68.6 & 111ALVM \\
\hline 41 & Seminole 11 & 420024091430401 & 719.0 & G, LF93 & 62.0 & 111ALVM \\
\hline 42 & Seminole 12 & 420015091441301 & 720.0 & G, LF93 & 58.0 & 111ALVM \\
\hline 43 & Seminole 13 & 420017091442101 & 720.0 & G, LF93 & 61.0 & 111ALVM \\
\hline 44 & Seminole 14 & 420020091442501 & 720.0 & G, LF93 & 59.0 & 111ALVM \\
\hline 45 & Seminole 15 & 420024091442701 & 720.0 & G, LF93 & 62.0 & 111ALVM \\
\hline 46 & Seminole 16 & 420029091443001 & 720.0 & G, LF93 & 65.0 & 111ALVM \\
\hline 47 & Seminole 17 & 420013091442001 & 720.0 & G, LF93 & 54.0 & 111ALVM \\
\hline 48 & Seminole 18 & 420013091442501 & 720.0 & G, LF93 & 52.0 & 111ALVM \\
\hline 49 & Seminole 19 & 420014091443201 & 720.0 & G, LF93 & 42.0 & 111ALVM \\
\hline 50 & Seminole 20 & 420017091443701 & 720.0 & G, LF93 & 43.0 & 111ALVM \\
\hline 51 & Seminole 21 & 420022091444001 & 720.0 & G, LF93 & 51.7 & 111ALVM \\
\hline 52 & Seminole 22 & 420029091444101 & 720.0 & G, LF93 & 58.7 & 111ALVM \\
\hline 53 & Seminole 23 & 420034091444101 & 720.0 & G, LF93 & 59.0 & 111ALVM \\
\hline \multicolumn{7}{|c|}{ Selected industrial and priviate wells } \\
\hline 314 & $\begin{array}{l}\text { Linn Co. Conserva- } \\
\text { tion Comm. }\end{array}$ & 420312091463801 & 730 & G & 105.0 & 110QRNR \\
\hline 328 & Pepsi-Cola Plant & 415834091394301 & 730 & $\begin{array}{l}\text { G, LS93, } \\
\text { WQI }\end{array}$ & 480.0 & 340DVSL \\
\hline 552 & Floyd Fetter & 415725091410101 & 805 & G, LS93 & 282.0 & 340DVSL \\
\hline 587 & Frank Mentzer & 420324091380501 & 877 & $\mathbf{G}$ & 115.0 & 340DVSL \\
\hline 589 & R.E. Knapp & 420318091390101 & 852 & $\mathbf{G}$ & 65.0 & 110QRNR \\
\hline 593 & $\begin{array}{l}1961 \text { Jennings } \\
\text { Reality }\end{array}$ & 420332091414301 & 853 & G, LS93 & 370.0 & 340DVSL \\
\hline 609 & Hazel Benka & 420359091493601 & 810 & $\mathbf{G}$ & 256.0 & 340DVSL \\
\hline 624 & Martin & 415929091440401 & 828 & $\begin{array}{l}\text { G, LS93, } \\
\text { WQI }\end{array}$ & 265.0 & 340DVSL \\
\hline 625 & Jerry Kindred & 420257091471901 & 750 & $\begin{array}{l}\text { G, LS93, } \\
\text { WQI }\end{array}$ & 110.0 & 340DVSL \\
\hline
\end{tabular}


Table 12. Information for selected wells and surface-water sites near Cedar Rapids, lowa—Continued

\begin{tabular}{|c|c|c|c|c|c|c|}
\hline $\begin{array}{l}\text { Site number } \\
\text { (see figs. } \\
\mathbf{2}-\mathbf{5} \text { for } \\
\text { location) }\end{array}$ & Site name & $\begin{array}{l}\text { U.S. Geological } \\
\text { Survey site identi- } \\
\text { fication number }\end{array}$ & $\begin{array}{l}\text { Land- } \\
\text { surface } \\
\text { eleva- } \\
\text { tion } \\
\text { (feet) }\end{array}$ & $\begin{array}{l}\text { Type of } \\
\text { data } \\
\text { collected }^{1}\end{array}$ & $\begin{array}{l}\text { Total } \\
\text { depth } \\
\text { drilled } \\
\text { (feet) }\end{array}$ & $\begin{array}{l}\text { USGS } \\
\text { aquifer } \\
\text { code }^{2}\end{array}$ \\
\hline \multicolumn{7}{|c|}{ Selected industrial and priviate wells - Continued } \\
\hline 630 & Kirk Schatzle & 420024091440401 & 760 & $\begin{array}{l}\text { G, LS93, } \\
\text { WQI }\end{array}$ & 200.0 & 340DVSL \\
\hline 635 & Lynch & 420322091455101 & 750 & G, WQI & 110.0 & 340DVSL \\
\hline \multicolumn{7}{|c|}{ Selected observation wells } \\
\hline 904 & $\begin{array}{l}\text { IGS-USGS } \\
\text { (Rockpile) }\end{array}$ & 415509091461801 & 842 & G, LW94 & 569.0 & 350SLRN \\
\hline 905 & $\begin{array}{l}\text { IGS-USGS } \\
\text { (Lincoln Church) }\end{array}$ & 420126091484701 & 842 & $\begin{array}{c}\text { G, LS93, } \\
\text { LW94 }\end{array}$ & 561.0 & 340DVSL \\
\hline 907 & $\begin{array}{l}\text { IGS-USGS } \\
\text { (Robins \#15) }\end{array}$ & 420508091395811 & 873 & $\begin{array}{c}\text { G, LS93, } \\
\text { LW94 }\end{array}$ & 520.0 & 350SLRN \\
\hline 908 & $\begin{array}{l}\text { IGS-USGS } \\
\text { (Hiawatha) }\end{array}$ & 420340091431601 & 805 & $\begin{array}{l}\text { G, LS93, } \\
\text { LW94 }\end{array}$ & 468.0 & 350SLRN \\
\hline 909 & $\begin{array}{l}\text { IGS-USGS } \\
\text { (Palo) }\end{array}$ & 420320091472201 & 743 & $\begin{array}{l}\text { G, LS93, } \\
\text { LW94 }\end{array}$ & 441.0 & 340DVSL \\
\hline 916 & 1993 USGS CRM-1 & 415949091405401 & 720.0 & $\begin{array}{l}\text { G, LF93, } \\
\text { LW94, } \\
\text { WQI }\end{array}$ & 42.5 & 111ALVM \\
\hline 917 & 1993 USGS CRM-2 & 420033091420301 & 720.0 & $\begin{array}{l}\text { G, LF93, } \\
\text { LW94, } \\
\text { WQI }\end{array}$ & 42.5 & 111ALVM \\
\hline 918 & 1993 USGS CRM-3 & 415953091435001 & 720.0 & $\begin{array}{l}\text { G, LF93, } \\
\text { LW94, } \\
\text { WQQ, C }\end{array}$ & 42.5 & 111ALVM \\
\hline 919 & 1993 USGS CRM-4 & 415953091435301 & 720.0 & $\begin{array}{l}\text { G, LF93, } \\
\text { LW94, } \\
\text { WQQ, C }\end{array}$ & 42.5 & 111ALVM \\
\hline 920 & 1993 USGS CRM-5 & 420408091470201 & 730.0 & $\begin{array}{l}\text { G, LF93, } \\
\text { LW94, } \\
\text { WQI }\end{array}$ & 37.0 & 111ALVM \\
\hline 935 & $\begin{array}{l}1993 \text { USGS } \\
\text { CRM-SD-1A }\end{array}$ & 420357091461301 & 749 & G, WQI & 15.0 & 110QRNR \\
\hline 936 & $\begin{array}{l}1993 \text { USGS } \\
\text { CRM-SD-1B }\end{array}$ & 420357091461302 & 749 & G, WQI & 30.0 & 110QRNR \\
\hline 937 & $\begin{array}{l}1993 \text { USGS } \\
\text { CRM-SD-2A }\end{array}$ & 420403091464602 & 734.16 & $\begin{array}{l}\text { G, LF93, } \\
\text { WQI }\end{array}$ & 30.0 & $110 Q R N R$ \\
\hline 938 & $\begin{array}{l}1993 \text { USGS } \\
\text { CRM-SD-2B }\end{array}$ & 420403091464601 & 734.13 & $\begin{array}{l}\text { G, LF93, } \\
\text { WQI }\end{array}$ & 15.0 & $110 Q R N R$ \\
\hline 941 & $\begin{array}{l}1993 \text { USGS } \\
\text { CRM-SD-4A }\end{array}$ & 420240091451501 & 730 & G, WQI & 15.0 & $110 Q R N R$ \\
\hline
\end{tabular}


Table 12. Information for selected wells and surface-water sites near Cedar Rapids, lowa-Continued

\begin{tabular}{|c|c|c|c|c|c|c|}
\hline $\begin{array}{l}\text { Site number } \\
\text { (see figs. } \\
2-5 \text { for } \\
\text { location) }\end{array}$ & Site name & $\begin{array}{l}\text { U.S. Geological } \\
\text { Survey site identl- } \\
\text { fication number }\end{array}$ & $\begin{array}{l}\text { Land- } \\
\text { surface } \\
\text { eleva- } \\
\text { tion } \\
\text { (feet) }\end{array}$ & $\begin{array}{c}\text { Type of } \\
\text { data } \\
\text { collected }\end{array}$ & $\begin{array}{l}\text { Total } \\
\text { depth } \\
\text { drilled } \\
\text { (feet) }\end{array}$ & $\begin{array}{l}\text { USGS } \\
\text { aquifer } \\
\text { code }^{2}\end{array}$ \\
\hline \multicolumn{7}{|c|}{ Selected observation wells- - Continued } \\
\hline 943 & $\begin{array}{l}1993 \text { USGS } \\
\text { CRM-SD-4B }\end{array}$ & 42024009141703 & 735 & G, WQI & 15.0 & 110QRNR \\
\hline 945 & $\begin{array}{l}1993 \text { USGS } \\
\text { CRM-SD-7 }\end{array}$ & 420230091453401 & 722.04 & $\begin{array}{l}\text { G, LF93, } \\
\text { LW94 }\end{array}$ & 16.5 & $110 Q R N R$ \\
\hline 946 & $\begin{array}{l}1993 \text { USGS } \\
\text { CRM-SD-11A }\end{array}$ & 420350091453801 & 740.59 & $\begin{array}{l}\text { G, LF93, } \\
\text { WQI }\end{array}$ & 15.5 & 110QRNR \\
\hline 947 & $\begin{array}{l}1993 \text { USGS } \\
\text { CRM-SD-11B }\end{array}$ & 420350091453802 & 740.58 & $\begin{array}{l}\text { G, LF93, } \\
\text { WQI }\end{array}$ & 21.0 & 110QRNR \\
\hline 951 & $\begin{array}{l}1993 \text { USGS } \\
\text { CRM-SD-15 }\end{array}$ & 415953091435002 & 722.32 & $\begin{array}{c}\text { G, LF93, } \\
\text { LW94, } \\
\text { WQI }\end{array}$ & 15.0 & 110QRNR \\
\hline 952 & $\begin{array}{l}1993 \text { USGS } \\
\text { CRM-SD-17 }\end{array}$ & 420313091451901 & 735.96 & $\begin{array}{l}\text { G, LF93, } \\
\text { WQI }\end{array}$ & 18.0 & $110 Q R N R$ \\
\hline 953 & $\begin{array}{l}1993 \text { USGS } \\
\text { CRM-SD-18 }\end{array}$ & 420328091445601 & 734.46 & $\begin{array}{l}\text { G, LF93, } \\
\text { WQI }\end{array}$ & 16.0 & 110QRNR \\
\hline 956 & $\begin{array}{l}1993 \text { USGS } \\
\text { CRM-SD-21A }\end{array}$ & 420038091443601 & 723 & G, WQI & 21.0 & 110QRNR \\
\hline 957 & $\begin{array}{l}1993 \text { USGS } \\
\text { CRM-SD-21B }\end{array}$ & 420038091443602 & 723 & G, WQI & 13.0 & 110QRNR \\
\hline 958 & $\begin{array}{l}1993 \text { USGS } \\
\text { CRM-SD-24 }\end{array}$ & 420041091442301 & 730.87 & $\begin{array}{l}\text { G, LW94, } \\
\text { WQI }\end{array}$ & -- & 110QRNR \\
\hline 959 & $\begin{array}{l}1993 \text { USGS } \\
\text { CRM-SD-26 }\end{array}$ & 420020091424101 & 721.08 & $\begin{array}{l}\text { G, LF93, } \\
\text { LW94, } \\
\text { WQI }\end{array}$ & 18.0 & 110QRNR \\
\hline 960 & $\begin{array}{l}1993 \text { USGS } \\
\text { CRM-SD-29 }\end{array}$ & 420021091440901 & 722.5 & G, WQI & 18.0 & $110 Q R N R$ \\
\hline 962 & $\begin{array}{l}1993 \text { USGS } \\
\text { CRM-SD-31 }\end{array}$ & 420020091431501 & 729 & G, WQI & 18.0 & $110 Q R N R$ \\
\hline 963 & $\begin{array}{l}1993 \text { USGS } \\
\text { CRM-SD-32 }\end{array}$ & 420024091421801 & 716.93 & $\begin{array}{c}\text { G, LF93, } \\
\text { LW94, } \\
\text { WQI }\end{array}$ & 18.0 & $110 \mathrm{QRNR}$ \\
\hline 965 & $\begin{array}{l}1993 \text { USGS } \\
\text { CRM-SD-34 }\end{array}$ & 420013091440701 & 720.41 & $\begin{array}{l}\text { G, LF93, } \\
\text { LW94, } \\
\text { WQI }\end{array}$ & 15.0 & $110 \mathrm{QRNR}$ \\
\hline 966 & $\begin{array}{l}1993 \text { USGS } \\
\text { CRM-SD-35 }\end{array}$ & 420004091444001 & 723 & G, LW94 & 10.0 & 110QRNR \\
\hline 967 & $\begin{array}{l}1993 \text { USGS } \\
\text { CRM-SD-36 }\end{array}$ & 420435091474701 & 736.28 & $\begin{array}{l}\text { G, LF93, } \\
\text { LW94, } \\
\text { WQI }\end{array}$ & 17.5 & 110QRNR \\
\hline 968 & $\begin{array}{l}1993 \text { USGS } \\
\text { CRM-SD-37A }\end{array}$ & 420321091454501 & 735 & $\begin{array}{l}\text { G, LF93, } \\
\text { WQI }\end{array}$ & 15.0 & $110 Q R N R$ \\
\hline
\end{tabular}


Table 12. Information for selected wells and surface-water sites near Cedar Rapids, lowa-Continued

\begin{tabular}{|c|c|c|c|c|c|c|}
\hline $\begin{array}{l}\text { Site number } \\
\text { (see figs. } \\
2-5 \text { for } \\
\text { location) }\end{array}$ & Site name & $\begin{array}{l}\text { U.S. Geological } \\
\text { Survey site identi- } \\
\text { fication number }\end{array}$ & $\begin{array}{l}\text { Land- } \\
\text { surface } \\
\text { eleva- } \\
\text { tion } \\
\text { (feet) }\end{array}$ & $\begin{array}{c}\text { Type of } \\
\text { data } \\
\text { collected }\end{array}$ & $\begin{array}{l}\text { Total } \\
\text { depth } \\
\text { drilled } \\
\text { (feet) }\end{array}$ & $\begin{array}{c}\text { USGS } \\
\text { aquifer } \\
\text { code }^{2}\end{array}$ \\
\hline \multicolumn{7}{|c|}{ Selected observation wells - Continued } \\
\hline 969 & $\begin{array}{l}1993 \text { USGS } \\
\text { CRM-SD-37B }\end{array}$ & 420337091465502 & 735 & G, LF93 & 31.5 & $110 Q R N R$ \\
\hline 974 & $\begin{array}{l}1993 \text { USGS } \\
\text { CRM-SD-40 }\end{array}$ & 420345091475601 & 746.30 & $\begin{array}{l}\text { G, LF93, } \\
\text { WQI }\end{array}$ & 17.5 & 110QRNR \\
\hline 975 & $\begin{array}{l}1993 \text { USGS } \\
\text { CRM-SD-41A }\end{array}$ & 420000091410001 & 720.74 & $\begin{array}{l}\text { G,LF93, } \\
\text { LW94, } \\
\text { WQI }\end{array}$ & 18.0 & 110QRNR \\
\hline 976 & $\begin{array}{l}1993 \text { USGS } \\
\text { CRM-SD-41B }\end{array}$ & 420000091410002 & 720.74 & $\begin{array}{l}\text { G,LF93,WQ } \\
\text { I }\end{array}$ & 24.0 & 110QRNR \\
\hline 977 & $\begin{array}{l}1993 \text { USGS } \\
\text { CRM-SD-42 }\end{array}$ & 420013091430601 & 710 & G,WQI & 3.0 & 110QRNR \\
\hline 978 & $\begin{array}{l}1993 \text { USGS } \\
\text { CRM-SD-43 }\end{array}$ & 420029091424801 & 710 & G,WQI & 3.0 & 110QRNR \\
\hline 979 & $\begin{array}{l}1993 \text { USGS } \\
\text { CRM-SD-44 }\end{array}$ & 415953091435401 & 720 & G,WQI & 7.0 & 110QRNR \\
\hline 986 & 1993 USGS CRM-6 & 415954091435301 & 725.0 & $\begin{array}{l}\text { G, LW94, } \\
\text { WQQ, C }\end{array}$ & 94.0 & $340 \mathrm{DVNN}$ \\
\hline 989 & $\begin{array}{l}1993 \text { USGS } \\
\text { CRM-SD-8 }\end{array}$ & 420241091455401 & 719.70 & G, LW94 & 17.0 & 110QRNR \\
\hline 990 & 1993 USGS CRM-7 & 420032091424701 & 721.0 & $\begin{array}{l}\text { G, LW94, } \\
\text { WQQ }\end{array}$ & 84.0 & 340DVNN \\
\hline 991 & 1993 USGS CRM-8 & 420314091452101 & 730.0 & $\begin{array}{l}\text { G, LW94, } \\
\text { WQI }\end{array}$ & 74.0 & 111ALVM \\
\hline 992 & 1993 USGS CRM-9 & 420032091424901 & 720.0 & $\begin{array}{l}\text { G, LW94, } \\
\text { WQQ }\end{array}$ & 32.0 & $111 \mathrm{ALVM}$ \\
\hline 993 & $\begin{array}{l}1993 \text { USGS } \\
\text { CRM-10 }\end{array}$ & 420030091424601 & 720.0 & $\begin{array}{l}\text { G, LW94, } \\
\text { WQQ }\end{array}$ & 38.0 & $111 \mathrm{ALVM}$ \\
\hline 994 & $\begin{array}{l}1993 \text { USGS } \\
\text { CRM-11 }\end{array}$ & 420033091420302 & 720.0 & G, LW94 & 85.0 & $340 \mathrm{DVNN}$ \\
\hline 995 & $\begin{array}{l}1993 \text { USGS } \\
\text { CRM-12 }\end{array}$ & 415949091405402 & 730.0 & G, LW94 & 75.0 & 340DVNN \\
\hline 996 & $\begin{array}{l}1993 \text { USGS } \\
\text { CRM-13 }\end{array}$ & 4203090914705 & 740.0 & G, LW94 & 145.0 & 110QRNR \\
\hline \multicolumn{7}{|c|}{ Selected surface-water sites } \\
\hline 701 & $\begin{array}{l}\text { Cedar River near } \\
\text { Seminole well } 10\end{array}$ & 415953091435300 & & C & -- & -- \\
\hline 702 & $\begin{array}{l}\text { Cedar River at } \\
\text { Edgewood Bridge }\end{array}$ & 420042901421700 & & WQQ & -- & -- \\
\hline 800 & $\begin{array}{l}\text { Municipal Water } \\
\text { Works }\end{array}$ & 420002091403200 & & WQQ & -- & -- \\
\hline
\end{tabular}

\footnotetext{
${ }^{1}$ Type of data collected: G, geologic; LQ, quarterly water levels; WQQ, quarterly water quality; WQI, intermittent water quality; C, continuous multiprobe data; LS93, summer 1993 water levels; LF93, fall 1993 water levels; LW94, winter 1994 water levels.

${ }^{2}$ USGS aquifer code: 110 QRNR, Quaternary System; 111ALVM, Holocene alluvium; 340 DVSL, Devonian-Silurian System; 340DVNN, Devonian System.
} 